Instituto de Química

Universidade de São Paulo

\title{
QSAR/QSAR-3D: ESTUDOS DE PARÂMETROS ESTRUTURAIS, ASPECTOS METODOLÓGICOS E APLICAÇÃO NO PLANEJAMENTO DE COMPOSTOS BIOATIVOS
}

Antonia Tavares do Amaral

Tese de Livre Docência

São Paulo

2003 
"Go confidently in the direction of your dreams ! Live the life you've imagined"

Thoreau 


\section{Agradecimentos}

Aos meus MESTRES Prof. Dr. Hugo Kubinyi e Prof. Dr. Paschoal E. Senise

Aos Profs. Drs. José Nicolau; Hans Viertler, Elizabeth Igne Ferreira, Antônio Flávio Midio, Etelvino H. Bechara, Emmanuel Vogel e Shirley Schreier e muitos outros que me motivaram incentivaram a enfrentar mais esta etapa.

Aos meus alunos de Pós-Graduação Rosely Baroni, Leoberto da Costa Tavares; Sylvia Regina de Mattos Miguel, Wander A. de Sousa; Maria das Graças Cardoso, José Ricardo Murari Pires; Hamilton Mitsugu Ishiki, Odonírio Abrahão Júnior; Cristiano Raminelli; Leonardo José Amaral de Siqueira; Alberto Malvezzi e Marcos Tulis Scotti e de Iniciação Científica: Wanderlei Cavassana; Gino Capobianco; Birgit Y. Frey; Antonio T. Gambôa, Yoshinori Miyazaki; Antonio B. Kawabe; Paulo L. Pereira ; Alexandre Gurgel; Cristina Saito; Mauro A. Persano; Maria do Rosário C. Alves; Carlos R. Brasil; Paulo M. de Avellar Silva; Maria Fernanda C. Ascenso; Kleber M. de Oliveira; Celina Y. Motizuki; Danilo S. Policastro; Weber C.F. Nunes da Silva; Ricardo S. Gonçalves; Vicente Godoy; Carlos H. Ramos; Annelies E. Kawanami e Gustavo T. Feliciano e, ainda outros que comigo conviveram por períodos curtos, cuja participação foi de extrema importância em todos os estudos desenvolvidos e, que muito me auxiliaram e também ensinaram a trilhar os caminhos nem sempre fáceis do amadurecimento científico.

A todos - por todos cantos do mundo - que de alguma maneira, contribuíram ao longo destes anos para o desenvolvimento deste trabalho como para meu crescimento pessoal, que seria impossível listar sem cometer injustiças que de alguma maneira.

Aos colegas do IQUSP, em especial Profs. Drs. Ana Maria da Costa Ferreira, Márcia Laudelina Arruda Temperini; Josef Wilhelm Baader e Luiz Henrique Catalani por terem contribuído para esta etapa ser mais agradável.

Aos funcionários do IQUSP pela manutenção da infra-estrutura em especial à Inocência Ferreira da Silva e Ênio Robson Braz

Ao colega Prof. Dr. Antônio Flávio Midio pela leitura do Memorial.

À Ana Luiza da Costa e Patrícia da Costa pela organização da documentação apresentada neste memorial.

Às Agências Financiadoras: FAPESP; CNPq; CAPES; Serviço Alemão de Intercâmbio Acadêmico (DAAD) e Fundação Alexander von Humdoldt pelos auxílios e bolsas concedidas e à tantas outras Instituições, que seria impossível listar sem cometer injustiças, que forneceram seu apoio.

Agradecimento especial ao Serviço Alemão de Intercâmbio Acadêmico (DAAD) pelo apoio, numa etapa crucial do desenvolvimento deste projeto. 


\section{$\underline{\text { Apresentacão }}$}

A meu ver, uma tese de Livre Docência como proposta atualmente deve fornecer ao leitor uma visão do trabalho desenvolvido pelo candidato, no contexto de sua linha de pesquisa. Desta forma, esta tese, embora descreva aspectos metodológicos e de aplicação de $Q S A R / Q S A R-3 D$ no planejamento de 02 séries de compostos bioativos estudados nos últimos 15 anos em nossos laboratórios no IQUSP, envolve uma quantidade considerável de conhecimentos adquiridos ao longo dos anos e a extensão dos conceitos utilizados originalmente em estudos mecanísticos em Físico-QuímicaOrgânica para sistemas mais complexos como o biológico (sendo ele isolado ou não). Finalmente, descrevo alguns aspectos da evolução, nesse período, de nossos trabalhos na área de pesquisa em $Q S A R$.

Nesta tese de Livre Docência, são apresentados tópicos selecionados, desenvolvidos durante a minha carreira científica como pesquisadora independente (TERCEIRA ETAPA, descrita no memorial). Esta compreende a fase, na qual procurei aplicar e estender os conhecimentos adquiridos durante vários anos desenvolvendo projetos de pesquisa na área de Físico-Química Orgânica - especialmente durante o mestrado e doutorado - ao entendimento das interações que ocorrem entre um composto químico e o sistema biológico. Em outras palavras, na medida em que o sistema biológico estudado permite, procuro descrevê-lo inicialmente propondo como modelo um sistema químico bem comportado. Certamente esta passagem não é direta apresentando limitações. Pode-se afirmar, no entanto, que muitas vezes, validado o "experimento" ou a premissa, o entendimento das diferenças observadas entre os sistemas modelo e o "real", pode contribuir com informações relevantes embora seja limitado seu poder preditivo.

O objetivo desta tese foi analisar, de modo crítico, tópicos selecionados da contribuição do nosso trabalho na área de $Q S A R / Q S A R-3 D$ - siglas em ingles para Relações Quantitativas entre Estrutura Química e $A$ tividade biológica e para Relações Quantitativas entre Estrutura Química e $A$ tividade biológica em Três Dimensões. Estas abordagens foram utilizadas visando o planejamento de compostos bioativos, ou melhor, o entendimento das interações que ocorrem no sistema biológico.

O texto apresentado não pretende ser uma revisão do tema. No entanto, procurei apresentar, de uma maneira ampla bem como crítica, aspectos e temas que na minha 
opinião são relevantes e que me nortearam, conduzindo a seleção tanto das abordagens metodológicas utilizadas bem como dos projetos de pesquisa desenvolvidos no laboratório de $Q S A R$, sob minha supervisão.

As referências bibliográficas indicadas têm como finalidade esclarecer dúvidas sobre tópicos que merecem uma maior reflexão.

Os assuntos foram apresentados em três capítulos, para melhor compreensão do leitor. No primeiro capítulo apresentamos uma introdução geral ao tema. O segundo capítulo apresenta e discute em detalhes diferentes aspectos das propriedades físicoquímicas ou estruturais responsáveis pela resposta biológica, em especial as de natureza: eletrônica/polar; hidrofóbica e estérica, para algumas das séries de compostos estudados no grupo. Apresentamos e discutimos ainda alguns aspectos metodológicos utilizadas nas abordagens $Q S A R / Q S A R-3 D$, incluindo exemplos do grupo. No terceiro capítulo apresentamos e discutimos modelos de $Q S A R / Q S A R-3 D$ propostos, ou seja as correlações estrutura-resposta biológica obtidas, para séries selecionadas de compostos bioativos, estudados no laboratório de $Q S A R$ e modelagem molecular neste Instituto. 


\section{CONTEÚDo}

CAPITULO I: PLANEJAMENTO RACIONAL DE MOLÉCULAS BIOATIVAS Introdução

CAPITULO II: RELAÇÕES QUANTITATIVAS ENTRE ESTRUTURA Introdução QUÍMICA E ATIVIDADE BIOLÓGICA: (QSAR/3D-QSAR)

II.1. Parâmetros Físico Químicos/Estruturais responsáveis pela resposta biológica

II.1.1. Parâmetros Hidrofóbicos/Lipofílicos

II.1.2. Parâmetros Eletrônicos, Estéricos e relacionados à polarizabilidade

II.2. Abordagens Metodológicas em $Q S A R / Q S A R-3 D$

Introdução

II.2.1. Abordagem extratermodinâmica (Abordagem de Hansch-Fujita) 55

II.2.2. Abordagem Free-Wilson e Mista (Hansch e Free-Wilson) 58

II.2.3. Relações Qquantitativas entre Estrutura Química e Atividade Biológica: em três Dimensões: $Q S A R-3 D$

II.2.3.1 $Q S A R 3 D$ quando a estrutura do receptor não é conhecida

II.2.3.2. $Q S A R 3 D$ quando a estrutura do receptor é conhecida

CAPITULO III: EXEMPLOS DE ANÁLISES DE $Q S A R / Q S A R-3 D$ APLICADAS A DIFERENTES SISTEMAS

Apresentação

III.1. Análises $Q S A R$ de compostos bioativos - estruturalmente análogos à procaína ou à procainamida - em especial com atividade anestésica local avaliados quanto à toxicidade aguda e avaliados quanto à atividade inibidora da transmissão do impulso nervoso

III.2. Análises $Q S A R$ de compostos bioativos, em especial de derivados nitrofurânicos 5-susbtituídos com atividade antibacteriana

REFERÊNCLAS BIBLIOGRÁFICAS

ANEXOS 


\section{CAPÍTULO I :PLANEJAMENTO RACIONAL DE MOLÉCULAS BIOATIVAS}

\section{Introdução}

A descoberta de compostos bioativos, durante décadas, não apresentou mudanças significativas encontrando-se na literatura, como fontes de estruturas-fundamentais (lead-structures), entre outras: produtos naturais isolados de plantas revelando, entre muitos outros exemplos, a morfina, extraída da papoula; a quinina e a quinidina, extraídas da casca da Cinchona sp., cocaína extraída das folhas da Erythoxylon coca; metabólitos secundários de microrganismos, associados à “descoberta”, por exemplo, da penicilina e conceitos bioquímicos, a partir por exemplo, da estrutura de ligantes endógenos (BÖHM, KLEBE, 1996; BÖHM et al, 2000). Frequentemente, no entanto, encontra-se compostos descobertos ao acaso "baseados" simplesmente na dedicação/intuição/sorte (KUBINYI, 1999). A seguir, nas estrututuras-fundamentais destes compostos, foram introduzidas modificações, de forma mais ou menos sistemática, levando a compostos com "melhor" atividade, ou seja, maior seletividade, maior biodisponibilidade, maior estabilidade e, ainda menor toxicidade e, menos efeitos adversos. Deve-se salientar, no entanto, que a grande maioria as mudanças estruturais foram baseadas na observação farmacológica e, ainda por tentativa e erro.

Atualmente, drástica mudança deste paradigma aconteceu, levando a uma revolução nas estratégias envolvidas no planejamento de compostos bioativos, principalmente de fármacos e de agrotóxicos. Esta mudança só foi possível com o surgimento de novas abordagens metodológicas associadas às novas tecnologias (KUBINYI, 1995; BÖHM, 2000), além da necessidade de se reavaliar os custos para se introduzir um novo produto (fármaco, por exemplo) no mercado. Entre as áreas de estudo que mais se desenvolveram estão: a Química Combinatória, a Engenharia Genética, a Cristalografia de Proteínas, Técnicas Multidimensionais em RMN, Relações Quantitativas entre Estrutura Química e Atividade biológica - QSAR (FUJITA, 1990; KUBINYI, 1995; KUBINYI, 1993; AMARAL et al, 1997; PIRES et al, 2001) Relações $Q$ uantitativas entre $E$ strutura química e $A$ tividade biológica em três dimensões - QSAR-3D - que inclui a Modelagem molecular, o Planejamento Racional (Design) 
dirigido para estrutura e Auxiliado por Computador, CADD (KUBINYI,1993; KUBINYI, 1998; KLEBE, 1999; BÖHM,1993; BÖHM, BOEHRINGER, BUR et al., 2000; KLEBE, 1993; ISHIKI et al, 2001; PIRES, 1998) bem como métodos Quimiométricos (CRIVORI, 2000; CRUCIANI, 1998, KASTENHOLZ, 2000).

Deve-se ressaltar, ainda, que nos dias de hoje, o avanço significativo no planejamento de um fármaco (por exemplo, com a utilização desta série de abordagens modernas e sofisticadas bem como da Robótica) permite sugerir de modo eficiente e acelerado inúmeras estruturas tridimensionais de "ligantes" que apresentam um ajuste perfeito a um determinado alvo biológico. No entanto, para um ligante se tornar um fármaco deve-se considerar também sua absorção, distribuição no sistema biológico, biotransformação (metabolismo) e excreção, os assim chamados parâmetros $\boldsymbol{A D M E}$ do ligante. Estas propriedades devem ser revistas e, também otimizadas, estando diretamente relacionadas à lipofilicidade do composto. Ressalta-se ainda a importância do QSAR clássico como uma ferramenta de grande valor, principalmente na compreensão da natureza e da contribuição das propriedades físico-químicas, identificadas como sendo responsáveis pela atividade (KUBINYI, 1993). 


\section{CAPÍTULO II. Relacões Ouantitativas entre Estrutura Química e $A$ tividade Biológica: $(O S A R / 3 D$ - QSAR)}

\section{Introdução}

O estudo de Relações Quantitativas entre Estrutura química e Atividade biológica (QSAR/QSAR-3D), utilizando diferentes estratégias metodológicas complementares, se estende a diferentes áreas de aplicação, como: planejamento e mecanismo de ação de fármacos e de agrotóxicos, na previsão da toxicidade de compostos, visando tanto sua aplicação terapêutica bem como para o meio ambiente. Na literatura são encontrados trabalhos aplicados a diferentes sistemas biológicos, apontando suas potencialidades, bem como as limitações de cada método (HANSCH, LEO, HOCKMAN, 1995; HANSCH, LEO, 1995; KUBINYI, 1993; KUBINYI, 1998).

A abordagem tradicional considera que a atividade biológica de um composto, é o resultado da(s) interação(ões) deste com a(s) diferente(s) biofase(s) podendo ser esta expressa pela contribuição de propriedades físico-químicas/estruturais ou de caraterísticas estruturais, identificadas como sendo responsáveis pela atividade, sendo estas descritas respectivamente por parâmetros físico-químicas/estruturais (Análise de Hansch) ou por Variáveis Indicadoras (Análise de Free-Wilson). Procura-se, desta forma, estender os conceitos utilizados nos estudos dos mecanismos de reação em Química Orgânica, (Físico-Química-Orgânica) para sistemas mais complexos, ou seja, no entendimento e na previsão de mecanismos que ocorrem em sistemas mais complexos, como sistemas bioquímicos e mesmo em animais de experimentação (HANSCH, LEO, HOCKMAN, 1995; KUBINYI, 1993; CHAPMAN, SHORTER, 1972; AMARAL, 1997; PIRES 2001).

Desta forma, a atividade biológica ou resposta biológica pode ser expressa como uma função de parâmetros estruturais, respectivamente lipofilicos, eletrônicos/polares, estéricos e, de dispersão. A aplicação desta abordagem envolve tanto a proposição de 
um modelo matemático adequado bem como a medida, ou o cálculo, dos parâmetros responsáveis pela atividade e de suas contribuições relativas para a mesma. A análise subseqüente dos resultados permite verificar a validade, limitações e poder de previsão do modelo proposto. A complexidade do modelo empregado, além da interação per se, dependerá de quanto exatamente essas interações podem ser expressas.(HANSCH, 1990; HANSCH ET AL., 1995; KYBINYI, 1998)

A abordagem tradicional, acima descrita, tem seu papel importante no planejamento de compostos bioativos, apesar de não considerar o arranjo tridimensional das moléculas. Permite, no entanto, elucidar o papel das propriedades físico-químicas responsáveis pelas interações composto-receptor(alvo biológico); entender o efeito da lipofilicidade e da ionização sobre a distribuição do composto no sistema biológico; introduzir e esclarecer o conceito de lipofilicidade "ótima" no transporte passivo de determinado fármaco, como por exemplo na absorção gastrintestinal ou na passagem através da barreira hematencefálica (barreira sangue-cérebro).

Mais recentemente, os métodos desenvolvidos em $Q S A R$ e em Modelagem Molecular são aplicados, simultaneamente, para descrever quantitativativamente as interações entre o composto e o sistema biológico, considerando seus aspectos tridimensionais. Portanto, esta abordagem denominada QSAR-3D complementa a primeira e, considera adicionalmente os aspectos estereoquímicos e topológicos das interações composto-alvo biológico. Estes contribuem e, muitas vezes, são o fator determinante da resposta ou atividade biológica.

\section{Estudos realizados em nossos laboratórios}

Meu interesse em desenvolver projetos envolvendo abordagens físico-químico orgânica aplicados a compostos bioativos, ocorreu devido a diferentes fatos e motivos, (apresentados detalhadamente no texto da apresentação do memorial) e em particular através da leitura do artigo Lipophilicity and Drug Activity (Kubinyi, H, Prog. Drug. Res. 23, 97-198, (1979)), no qual Kubinyi apresenta a(s) interação(ões) compostosistema biológico-salientando seus aspectos físico-químico orgânicos. Nesta publicação, entre outros aspectos, são discutidos os fatores entrópicos nas interações de natureza hidrofóbica e, sua importância na determinação da resposta biológica, aspecto este que ainda não havíamos considerado, até então. Nosso grupo de trabalho preocupava-se, 
preponderantemente, com a contribuição dos os efeitos eletrônicos para a resposta biológica. Na época estudávamos compostos com atividades anestésica local. (ANEXO M-2) (DOC.9.3.6.1-16) (ANEXO IX) e série de tiossemicarbazonas com atividade antibacteriana (ANEXO M-1)

No entanto, a partir destes fatos e, dos motivos relatados no memorial, nas análises de SAR (Structure Activity Relationships) e de QSAR realizadas, expandimos tanto a natureza dos parâmetros físico-químicos/estruturais estudados bem como as correspondentes as faixas de variação correspondentes. Assim, incluímos para todas as séries de compostos analisados parâmetros hidrofóbicos, sendo estes estudados nos seus diferentes aspectos, relativos respectivamente à(ao): metodologia (ANEXO IV);(ANEXO VI); (ANEXO M-4) e (ANEXO M-8);estudo de interações intra- e inter-moleculares englobadas no $\log P$ (ANEXO M-2); (ANEXO III); (ANEXO V); (ANEXO VI); correções para Ionização e construção de perfil $\log P$ versus $p H$ (ANEXO M-8); (ANEXO IV); correlações com outros sistemas de partição (DOCs. .3.2.2-9 a DOCs. .3.2.2-13) e, trabalho em colaboração com outros grupos (ANEXO XII); (ANEXO XIII) (DOC. .9.3.6.1-51).

Simultaneamente, ampliamos as séries ou coletâneas de parâmetros eletrônicos, incluindo os espectroscópicos, tais como: $v_{\mathrm{C}=0}(\mathrm{ANEXO} \mathrm{IV)} \mathrm{;} \mathrm{(ANEXO} \mathrm{IX);} \mathrm{(ANEXO}$ I) (ANEXO II) e, $\delta^{13}$ C=o ( ANEXO XIV); (ANEXO M-6) ; (ANEXO M-7) e obtidos por voltametria cíclica, tipicamente $\boldsymbol{E}$ (potencial de redução) (ANEXO VI) ; (ANEXO VII); (ANEXO D-II) e, por cálculo, tipicamente cargas atômicas (ANEXO XIV);(DOC.9.3.2.1-20) com o objetivo de incluir nos modelos de QSAR, parâmetros experimentais, validados para cada sistema, ou seja para cada série de compotos estudados. Deste modo, procurou-se tanto contribuir para a compreensão da(s) natureza(s) do(s) efeito(s) eletrônico(s) transmitido(s) por um substituinte ou, grupo desubstituintes, como avaliar a variação da densidade eletrônica do sistema.

Finalmente, na dissertação de mestrado de Sylvia de Mattos Miguel, (ANEXO II) (ANEXO M-3) foram incluidos na análise de QSAR (discutida no CAPÍTULO III) análogos da procaína orto-substituídos. Nesta foram analisados tanto a(s) natureza(s) da transmissão do(s) efeito(s) eletrônico(s) transmitido pelo substituintes sobre sobre $v_{\mathrm{C}=\mathbf{O}}$ 
bem como o efeito de grupos volumosos, expressos pelo parâmetros estéricos ( $\mathbf{E}_{\mathrm{s}}(\mathbf{A M D})$.

\section{Resumindo nossas atividades e contribuições nesta área de pesquisa}

Em 1988/1989, iniciei trabalhos na área de QSAR, na época ainda incipiente em nosso meio, procurando estender os conhecimentos por nós adquiridos nos estudos de mecanismo de reações em química orgânica, durante o mestrado e doutorado, agora à sistemas biológicos. Através da aplicação das estratégias e metodologias utilizadas em QSAR e, com o objetivo de verificar o(s) efeito(s) das modificações estruturais sobre a atividade(s), pretendíamos fornecer subsídios, entre outros, para a síntese de derivados mais ativos e menos tóxicos.

A partir de 1989 diversos aspectos dos estudos de Relações Quantitativas entre Estrutura química e Atividade biológica (QSAR) e (QSAR-3D) começaram a ser desenvolvidos em nosso grupo de pesquisa no Laboratório de QSAR e Modelagem Molecular, neste Instituto. Entre eles, o estudo e a determinação de propriedades físicoquímicas/estruturais (eletrônicas, lipofilicas, estéricas e aquelas relativas à polarizabilidade) de compostos com atividade biológica, em especial de anestésicos locais e de bloqueadores da transmissão do impulso nervoso, estruturalmente análogos da procaína (TAVARES. L.C., 1987; AMARAL,ET AL.,1991, AMARAL,. ET AL .1993, AMARAL,. ET AL,.1996, MIGUEL, 1992; SOUSA, 1997; AMARAL et al., 1997; MALVEZZI, et al., 2001; TAVARES \& AMARAL, 1997; SIQUEIRA, 2001; MALVEZZI, 2003); de antibacterianos (BARONI, 1987; TAVARES. L.C., 1993) incluindo-se derivados nitrofurânicos 5-substituídos (PIRES, 1998; PIRES et al., 2000; PIRES et al., 2001); de antitumorais derivados de sais de alquilamônio de $\mathrm{N}$-alquil arilcetonas substituídas RAMINELI, 2001) e, mais recentemente de derivados não nucleosídeos inibidores da transcriptase reversa (NNRTI) do vírús HIV-1 (ISHIKI, 1999; ISHIKI et al., 2001), de derivados pirídínicos-alfa-substituídos inibidores potencias da Ribonucleotideo Reductase da Mycobacterium tuberculosis e de derivados nitrofurânicos como antichagásicos. 
Em todos projetos de nosso grupo de pesquisa no Laboratório de $Q S A R$ e Modelagem Molecular, no IQUSP procuramos, de um modo geral, desenvolver e/ou aplicar as metodologias utilizadas em $Q S A R / Q S A R-3 D$ para descrever, de modo quantitativo, a(s) interação(ões) entre o composto químico e o sistema biológico e, assim procuramos contribuir para elucidar o(s) mecanismo(s) das interações expressas por cada um dos parâmetros/características estruturais, bem como, na medida do possível, do mecanismo de ação e prever derivados mais potentes.

Comentário: Adicionalmente, compreendendo que a formação de pessoal qualificado na área é crucial, particularmente nesta área multidisciplinar e com inovações significativas, procuramos fazer com que os projetos desenvolvidos em QSAR em nossos laboratórios, na medida do que nos é possivel, envolvam planejamento e síntese de séries de compostos que tèm suas propriedades fisico-químicas determinadas, calculadas elou retiradas da literatura bem como os parâmetros biológicos determinados, havendo uma participação efetiva do aluno em todas as etapas ou, no mínimo, sua colaboração ou acompanhamento.

\section{II.1.Parâmetros Físico-Químicos e/ou Estruturais responsáveis pela resposta biológica}

Parâmetros que expressam/representam certas características estruturais bem como propriedades de compostos bioativos são necessários para que se possa propor modelos de $Q S A R$, ou seja, estabelecer correlações quantitativas entre a(s) atividade(s) biológica(s) e as correspondentes estruturas químicas. Especialmente importantes são as propriedades físico-químicas ou estruturais dos compostos que estão diretamente relacionadas às forças intermoleculares envolvidas na interação "ligante"-alvo (receptor) biológico, bem como às relacionadas ao transporte e à distribuição dos mesmos.

\section{Interações ligante-alvo (receptor) biológico}

Entre os diversos processos que ocorrem com uma molécula introduzida em um sistema biológico citam-se a degradação, a absorção, a distribuição, a interação com um alvo (receptor) biológico para o desencadeamento de um efeito. Estudos de QSAR 
podem ser aplicados ao estudo de cada um destes eventos, em sistemas biológicos de diferentes complexidades. Assim, pode-se realizar estudos de QSAR em sistemas constituídos de animais de experimentação, onde tanto a degradação como a distribuição e a interação composto-químico/alvo biológico são importantes para o efeito total observado. Idealmente, no entanto, inicia-se o estudo, quando possível, por um sistema biológico mais simples, um sistema isolado, por exemplo um receptor isolado. Verifica-se neste caso, quais são as características específicas do composto para a perfeita interação e ajuste com o receptor. Uma vez otimizada a estrutura do composto para um ajuste perfeito, modificações, menos específicas, podem ser introduzidas para melhorar as propriedades quanto a sua biodisponibilidade no sistema biológico mais complexo.

A intensidade da interação entre o composto químico (denominado ligante, $\underline{\mathbf{L}}$ ), com seu alvo (receptor) biológico, na formação de um complexo (ligante-receptor, $\underline{\mathbf{L}}-\underline{\mathbf{R}}$ ) depende das complementaridades estérica e eletrostática destes. Cabe a QSAR explicar a afinidade observada de diferentes ligantes, expressas por exemplo por $\mathbf{K}_{\mathbf{m}}, \mathbf{K}_{\mathbf{i}}, \mathbf{I C}_{\mathbf{5 0}}$, $\mathbf{L D}_{50}, \Delta \mathbf{G}$ e a seguir, poder prever a afinidade de ligantes $(\underline{\mathbf{L}})$ ainda não estudados.

A variação de energia livre $(\Delta \mathbf{G})$ associada à formação de um complexo ligantereceptor $(\mathbf{L}-\mathbf{R})$ é a somatória das variações de energia livre associadas às interações de naturezas eletrostática, indutiva, não polar e, hidrofóbica que ocorrem entre as duas moléculas - ligante e alvo biológico (receptor) - e as moléculas do solvente.

A figura II.1.1 apresenta esquematicamente os fatores energéticos envolvidos na interação L-R bem como o desmembramento da variação de energia livre associada à interação ligante-receptor em termos entálpicos e entrópicos.

As interações de natureza eletrostática são de três tipos distintos: carga-carga (íoníon), carga-dipolo, (íon-dipolo) ou dipolo-dipolo. Estas podem ter características atrativa ou repulsiva. As ligações de hidrogênio, por exemplo, podem ser classificadas como sendo interações dessa natureza (ANDREWS, P.R.,1993).

As interações de natureza indutiva ocorrem entre grupos tanto carregados ou polares como não polares, mas polarizáveis. A aproximação do grupo carregado ou polar causa a formação de um dipolo induzido no grupo polarizável. Esta interação é sempre atrativa. 
As interações de natureza não-polares, como por exemplo forças de dispersão ou de London, ocorrem entre grupos não-polares. Estas são forças atrativas oriundas de dipolos instantâneos, não permanentes, causados pelo movimento eletrônico em grupos apolares. É o tipo de força que mantém moléculas apolares juntas no estado líquido. Outro tipo de interação não-polar é de natureza estérica. São forças de repulsão que ocorrem quando se tenta aproximar átomos à distâncias menores do que a soma dos seus raios de van der Waals. O balanço líquido entre as forças de dispersão de London (atrativas) e as de repulsão estérica são expressas pelo potencial de Lennard-Jones e, este saldo energético controla a aproximação máxima de dois grupos apolares. As interações hidrofóbicas, são de natureza predominantemente entrópica. Estas advém do fato de que na etapa em que o complexo ligante-receptor(alvo biológico) está dissociado, as moléculas de água tem de se organizar ao redor das superfícies tanto do ligante como do receptor, mesmo que estas sejam de natureza apolar. Com a formação do complexo ligante-receptor, as moléculas de água que solvatavam as superfícies de interação são liberadas adquirindo um estado entropicamente mais favorável ou seja menos organizado. Isto representa um ganho energético que favorece a formação do complexo ligante-receptor.

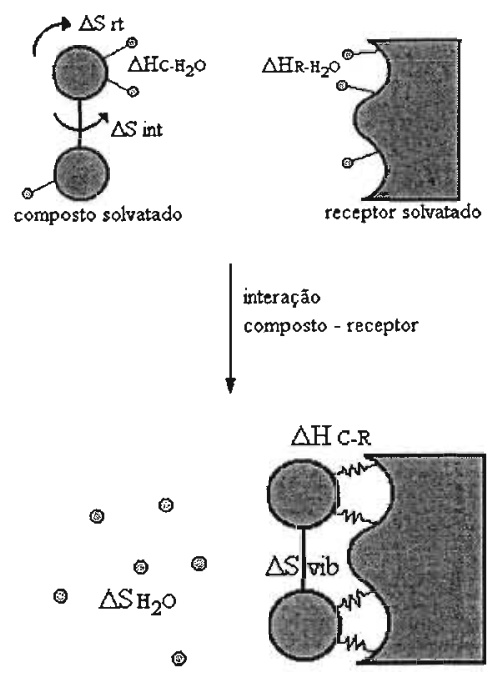

Figura II.1.1. Termodinâmica da interação ligante-receptor: fatores entálpicos e entrópicos envolvidos (ANDREWS, PR, 1993) 
Na figura II.1.1, $\Delta \mathbf{H}_{\mathrm{C}_{-\mathrm{H}_{2}} \mathrm{o}}$ e $\Delta \mathbf{H}_{\mathbf{R}-\mathrm{H}_{2} \mathrm{O}}$ são os termos entálpicos, respectivamente de solvatação do composto e do receptor, ou seja, a energia que precisa ser fornecida para a dessolvatação; $\Delta \mathbf{S}_{\mathbf{r t}}$ é a energia que precisa ser fornecida devido à diminuição da entropia do sistema pela diminuição de graus de liberdade de rotação e de translação do ligante; $\Delta \mathbf{S}_{\text {int }}$ é a energia que precisa ser fornecida devido a diminuição de flexibilidade conformacional; $\Delta \mathbf{H}_{\mathbf{C}-\mathbf{R}}$ é a energia liberada das complementaridade estérica e eletrostática (ajuste) do ligante e do receptor; $\Delta \mathbf{S}_{\mathbf{H}_{2}} \mathbf{o}$ é a energia liberada pelo aumento de entropia das moléculas de água que deixam de estar estruturadas ao redor das superfícies de contato do ligante e do receptor; $\Delta \mathbf{S}_{\mathbf{V i b}}$ é a entropia residual de vibração do complexo ligante-receptor. As interações eletrostáticas e indutivas entre o ligante e o solvente estão expressas no termo $\Delta \mathbf{H}_{\mathrm{C}-\mathrm{H}_{2}} \mathbf{O}$ e, corresponde a uma gasto de energia, ou seja, é uma quantidade de energia que precisa ser fornecida para separar as moléculas de água das do ligante. Da mesma forma, as interações eletrostáticas e indutivas entre a água e o receptor compõe o termo $\Delta \mathbf{H}_{\mathbf{R}-\mathbf{H}_{\mathbf{2}} \mathbf{O}} \mathrm{O}$ termo $\Delta \mathbf{H}_{\mathbf{C}-\mathbf{R}}$ expressam as energias relativas às interações eletrostáticas, indutivas e não polares entre o ligante e o receptor enquanto que o termo $\Delta \mathbf{S}_{\mathbf{H}_{\mathbf{2}} \mathbf{O}}$ se refere às interações hidrofóbicas, ou seja, aumento da entropia da água por ocasião da formação do complexo ligante-receptor. A variação de energia livre que ocorre na formação do complexo ligante-receptor é a somatória de todos esses fatores apontados acrescida de mais dois termos. $\mathrm{O}$ primeiro, $\Delta \mathbf{S}_{\mathrm{rt}}$ é devido à diminuição da entropia do ligante, por perda das liberdades de rotação e de translação e o segundo $\Delta \mathbf{S}_{\mathbf{i n t}}$ esta associado à perda entrópica relativa ao ligante, devido a perda liberdade conformacional por ocasião da formação do complexo. Estes dois últimos termos de natureza entrópica se transformam apenas em uma entropia residual vibracional no complexo ligante-receptor $\Delta \mathbf{S}_{\text {vib }}$.

\section{II.1.1.Parâmetros Hidrofóbicos/Lipofílicos}

Despertam enorme interesse e são muito freqüentes em QSAR, trabalhos envolvendo estudos sobre lipofilicidade e os correspondentes parâmetros lipofílicos ou hidrofóbicos. A lipofilicidade, é considerada como uma das propriedades físico- 
químicas responsável pela atividade biológica, ou seja, responsável tanto pelos processos de solubilização, de penetração, de distribuição e de metabolismo de um composto no sistema biológico bem como pelas interações não-específicas que ocorrem na aproximação do composto ao(s) seu(s) alvo(s) biológico(s).

$\mathrm{E}$, mais recentemente, salienta-se a importância do estudo das interações hidrofóbicas, visando a otimização da lipofilicidade de um composto bioativo (ligante) e, portanto, das propriedades farmacocinéticas de moléculas candidatas a fármacos, já nas etapas iniciais de desenvolvimento de um novo fármaco. $\mathrm{E}$, como ressaltado anteriormente neste texto, reconhece-se atualmente que, muitas vezes, moléculas candidatas a fármacos, propostas por estudos de $Q S A R-3 D$, como por exemplo, baseados apenas na estrutura do receptor, não se tornam fármacos por não apresentarem adequadas propriedades farmacocinéticas (ADME: absorção, distribuição, biotransformação(metabolismo) e excreção). (KUBINYI, 1998, MARTIN, 1998; SCHERRER, 2001, PLISKA, V., TESTA, 1996)

Lipofilicidade de um composto é definida como a partição deste nas fases aquosa e não aquosa, como por exemplo n-octanol/água. O coeficiente de partição, $\boldsymbol{P}$, é, freqüentemente usado em análises de $Q S A R$ para descrever de modo quantitativo as características hidrofóbicas de um composto biologicamente ativo.

Entre os parâmetros freqüentemente empregados em modelos de $Q S A R$ para expressar a lipofilicidade (ou hidrofobicidade) estão o logaritmo do coeficiente de partição n-octanol/água, $\log \boldsymbol{P}$ (KUBINYI, 1993; AMARAL et al., 1991, AMARAL et al., 1993, AMARAL et al., 1995; AMARAL et al., 1997; PIRES et al., 2001; ALVES, 1997; MALVEZZI, 2001; RAMINELLI, 2001; SIQUEIRA, 2001; RANDO, D et al, 2002;), sendo este determinado experimentalmente ou obtido por cálculo e, a constante hidrofóbica relativa aos substituíntes $\pi$ de Hansch-Fujita, retirada da literatura (KUBINYI, 1993) ou obtida, para o sistema específico, a partir dos valores experimentais de $\log P$ (ALVES, 1997; SIQUEIRA, 2001; RAMINELLI, 2001; AMARAL, ET $A L, 1997)$.

O coeficiente de partição $n$-octanol/água $(\boldsymbol{P})$ de um composto é definido como sendo a relação entre as concentrações do referido composto, $\mathbf{C}$, nestas duas fases, em condições de equilíbrio podendo ser expresso pela equação II.1.1-1: 


$$
P=[C]_{n-o c t a n o l} /[C]_{\text {água }}
$$

equação II.1.1-1

Para moléculas contendo grupos ionizáveis o equilíbrio ácido-base deve ser considerado na partição e, define-se $\log P_{\text {app }}$, coeficiente de partição aparente, que inclui uma correção para ionização na partição (Figura II.1.1-1)

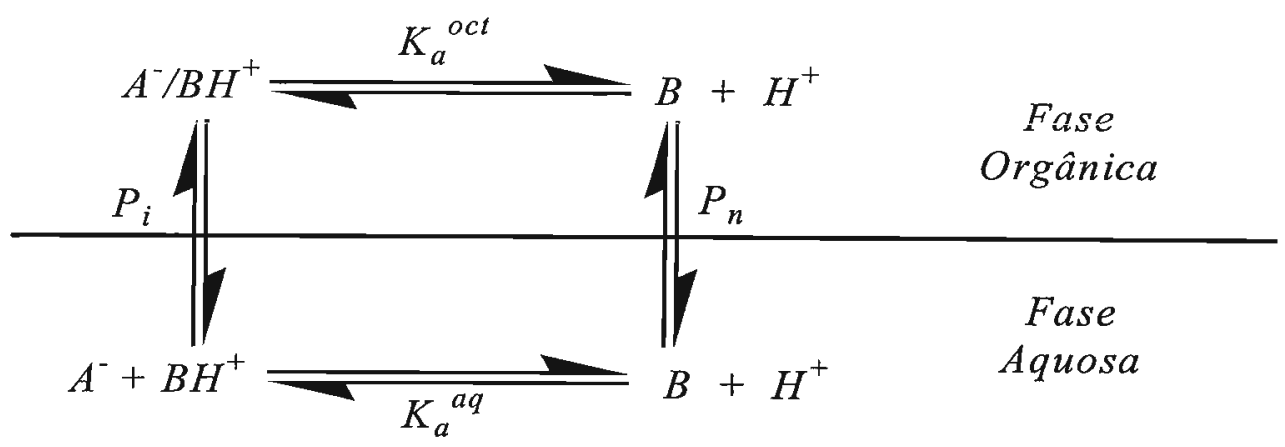

$\log \boldsymbol{P}_{\mathrm{i}}$ : logaritmo do coeficiente de partição da espécie ionizada, $\mathbf{B H}^{+}$; $\left[A^{-}\right]$: concentração molar do contra-íon, $\mathrm{A}^{-}$;

$\log P_{\mathrm{n}}$ : $\operatorname{logaritmo~do~coeficiente~partição~da~espécie~não-ionizada,~} \mathbf{B}$;

$\boldsymbol{K}_{a}^{a q}:$ constante de ionização da espécie $\mathbf{B H}^{+}$, na fase aquosa e,

$\boldsymbol{K}_{a}^{o c}$, : constante ionização da espécie $\mathbf{B H}^{+}$, na fase orgânica (octanol).

Figura II.1.1-1 Representação esquemática dos equilíbrios simultâneos que ocorrem durante a partição de uma base fraca, B. (COMER \& TAM, 2001; SCHERRER, 2001).

Na partição de compostos contendo grupos ionizáveis, encontram-se trabalhos explorando outros aspectos, importantes para a partição, como: os efeitos das variações da concentração, da força iônica verificando-se as possibilidades de formação de pariônico, além é claro das variações nos valores de pH (SCHERRER, 2001; MALVEZZI, 2001, MALVEZZI, 2003). Citam-se exemplos nos quais a maior lipofilicidade do pariônico, em relação aos ions "livres", pode influenciar a passagem através das membranas biológicas, sendo esta a espécie responsável pela atividade (SCHERRER, 2001).

Dentro deste contexto e considerando em especial a determinação dos valores do coeficiente de partição dentro da precisão analítica requerida bem como o entendimento das informações sobre as interações intra- e intermoleculares envolvidas, ou "codificadas", no coeficiente de partição (sendo estas que governam o reconhecimento 
do fármaco para interagir com o alvo biológico, explicando muitas das correlações observadas entre lipofilicidade e atividade biológica) em nosso laboratório estudamos a lipofilicidade, expressa pelo valores de $\log P_{\text {app }}$ de séries de compostos, compilados/agrupados no texto desta tese da seguinte forma:

i. Séries de análogos estruturais da procaína e da procainamida, reconhecidos na literatura como anestésicos locais, respectivamente:

\section{Séries I:}

Ia: cloretos de [2-benzoiloxi-etil]dimetilamônio, para-substituídos;

Ib: cloretos de [2-benzoiloxi-etil]dimetilamônio, orto-substituídos e,

Ic: cloretos de [2-benzoiloxi-etil]dimetilamônio, meta-substituídos.

\section{Séries II:}

II.a: cloretos de $N$-[(dimetilamino)metil]benzamidas, para-substituídos

Séries III: Compostos avaliados quanto a atividade inibidora da transmissão do impulso nervoso

IIIa. brometos de [2-(benzamido)etil]benzildimetilamônio, para-substituídos

IIIb. cloretos derivados da procaína, com estruturas diversas.

ii. Série de derivados 5-nitrofurânicos, com atividade antibacteriana

\section{Séries IV:}

IV.I. 2-(5-nitro-2-furfurilideno)-3-oxo-2,3-di-hidrobenzofuranos substituídos

IV.II. 1-(2-hidróxi-fenil)-3-(5-nitro-2-furil)-2-propen-1-onas) substituídas

IV.III 1-(2-acetilóxi-fenil)-3-(5-nitro-2-furil)-2-propen-1-onas) substituídas

E, ainda, nossa contribuição relacionada aos aspectos metodológicos serão descritos e discutidos posteriormente (vide Algumas considerações sobre as metodologias empregadas)

Os compostos das séries de análogos estruturais da procaína e da procainamida (séries I e II e, mais recentemente série III) reconhecidos na literatura como anestésicos locais foram planejados e sintetizados, considerando-se que do ponto de vista estrutural, a grande maioria dos anestésicos locais apresentam, uma porção lipofilica, geralmente um sistema aromático, uma cadeia carbônica alifática intermediária e uma porção hidrofílica, freqüentemente o grupo amino 
substituído(STRICHARTZ, 1987). Embora, o mecanismo de ação ao nível molecular, ainda não esteja totalmente esclarecido (RECANATINI, 1988), considera-se que o equilíbrio entre as porções lipofílica e hidrofilica influencia significativamente a potência anestésica local, tornando-se importante o estudo de parâmetros lipofilicos. STRICHARTZ, 1987

Em nosso trabalho, (AMARAL, et al.,1991, AMARAL,. et al ,.1993, AMARAL,. et al,.1997, SOUSA, 1997; AMARAL et al., 1997) a escolha da série de benzoatos para-substituídos (série Ia) foi feita sabendo-se, entre outras, da baixa toxicidade observada para os correspondentes produtos de biotransformação (metabolização), exceção feita ao para-amino derivado (STRICHARTZ, 1987). Procurava-se, deste modo, não introduzir mais este fator (toxicidade dos produtos de biotransformação), que deveria ser considerado nas etapas posteriores.

No entanto, os compostos se mostraram, frente ao sistema biológico, muito mais susceptíveis a hidrólise, dentro do período requerido para o experimento, do que seria desejado. Este fato, indesejável, poderia vir não só dificultar os experimentos biológicos mas também poderia comprometer a precisão dos valores de atividade biológica, como foi por nós observado em alguns dos derivados substituídos na posição para, em especial com grupos aceptores de elétrons, como por exemplo para o 4- $\mathrm{SO}_{2} \mathrm{CH}_{3}$ derivado. (Os valores de $\mathrm{LD}_{50}$, em camundongo, foram determinados em colaboração com Prof. Dr. A.C. de Oliveira, ICB, USP,SP).

Assim, com o objetivo de se diminuir o grau de hidrólise e, ao mesmo tempo dispor de séries de compostos com uma ampla faixa de variação de lipofilicidade, para uma posterior análise de $Q S A R$, ampliamos a série incluindo 12 análogos da procaína com grupos nas posições orto, mono e di-substituídos. Para a série resultante, série Ib foi observado um aumento nos valores da potência, quando comparados com os correspondentes derivados para-substituídos. (TABELA II.1.1-1, ANEXO II)

Outro aspecto importante a ser salientado é que na série resultante (séries Ia e Ib; 28 compostos), incluindo-se compostos mais potentes, a faixa de variação do parâmetro biológico é ampla, aspecto fundamental a ser considerado em estudos de QSAR.

Considerando que o sistema resultante se tornou interessante do ponto de vista estrutural, adicionalmente, realizamos a análise da(s) natureza(s) da transmissão do(s) efeito(s) eletrônico(s) transmitido pelo substituintes sobre sobre $v_{\mathrm{C}=0}$ bem como o 
efeito de grupos volumosos, expressos pelo parâmetro $\mathbf{E}_{\mathbf{s}}(\mathbf{A M D})$, proposto por Fujita e colaboradores (SOTOMATSU, T ; FUJITA, T. 1990). Os resultados deste estudos serão discutidos a seguir, no ítem relativo ao parâmetro eletrônico.

Em um sistema complexo como o estudado, utilizando-se animais de experimentação, ainda permanece em aberto quais dos efeitos modulam a resposta biológica, ou seja, a toxicidade aguda. No entanto, os resultados observados indicam que o gráu de estabilidade do composto tem sua contribuição juntamente com outros fatores como a lipofilicidade.

Estes estudos, em parte por mim desenvolvidos, fizeram parte do projeto de trabalho, focalizando especificamente aspectos metodológicos em QSAR (DOC.6.6.4, DOC.6.6.5 e, DOC. 6.6.6 ), e, da dissertação de mestrado de Sylvia de Mattos Miguel, e do projeto de iniciação científica de Birgit Yara Frey e constam de publicações (ANEXO M-2) (ANEXO I) (ANEXO II) e DOC. 9.3.6.1-23. As análises de QSAR resultantes serão discutidas no CAPÍTULO III.1.

Para as séries Ia e Ib, os valores do coeficiente de partição foram obtidos por cálculo $\left(\log P_{\text {calc }}\right)$ e, determinados experimentalmente pelos métodos shake-flask $\left(\log P_{\text {app }}\right)^{\mathbf{S F}}$ e por CLAE $\left(\log P_{\text {app }}\right)^{\mathbf{C L A E}}$, respectivamente. Os valores resultantes constam da Tabela II.1.1-1.(ANEXO II)

Para as séries Ia e Ib, os valores obtidos foram validados, como parâmetros hidrofóbicos, refletindo a lipofilicidade da molécula toda. Estes valores, com exceção de $\log P_{\text {calc, }}$ que não considera a contribuição da ionização para partição, incluíram a correção para ionização. As duas metodologias foram também aplicadas com sucesso.

Adicionalmente, para o 4-metoxiderivado foi estudado o efeito da variação do valor de $\log P_{\text {app }}$ em função do $\mathrm{pH}$, construindo-se um gráfico do perfil de variação $\log P_{\text {app }}$ versus $\mathrm{pH}$, aspecto retomado posteriormente em nosso grupo. Analisando-se também o efeito da composição do tampão (Trizma ou Fosfato), não sendo observada variação significativa no valor de $\log P_{\mathrm{app}}$, para $\mathrm{pH}$ 7.4.

Ao redigir este texto, algumas correlações foram refeitas e, observa-se uma melhoria da correlação de $\log P_{\text {app }}$ versus $\log P_{\text {calc, }}$, ao se incluir uma variável indicadora da presença/ausência de grupamentos na posição orto. ( $\mathbf{I}_{\text {orto }}$ ). Resultado semelhante é observado ao se incluir o parâmetro estérico proposto por Fujita $\left(E_{s}(A M D)\right.$, equações II.1.1-2 a II.1.1-4. Estes não haviam sido considerados na trabalho inicial e, 
pretendemos incluir no manuscrito para ser submetido à publicação. Na época, estes dados não foram publicados em artigo mais extenso, pois considerávamos como resultados parciais, visto nosso objetivo principal era determinar a atividade anestésica local e não o estudo da toxicidade aguda (Vide comentários específicos apresentados no memorial e no item considerações finais).

$$
\begin{aligned}
& \log P_{\text {app }}{ }^{(\mathrm{HPLC})}=1.00( \pm 0.08) \log P_{\text {calc }}-1.25( \pm 0.23) \\
& \mathrm{n}=28 \quad \mathrm{r}=0.981 \quad \mathrm{~s}=0.207 \quad \mathrm{~F}=662.11 \quad \mathrm{r}^{2} \mathrm{cv}=0.958 \quad \mathrm{~s}_{\text {PRESS }}=0.219 \\
& \log P_{\text {app }}{ }^{(\mathrm{HPLC})}=0.98( \pm 0.07) \log P_{\text {calc }}-0.20( \pm 0.15) \mathrm{I}_{\text {orto }}-1.12( \pm 0.23) \\
& \mathrm{n}=28 \quad \mathrm{r}=0.986 \quad \mathrm{~s}=0.184 \quad \mathrm{~F}=421.49 \quad \mathrm{r}^{2} \mathrm{cv}=0.964 \quad \mathrm{~S}_{\text {PRESS }}=0.206 \\
& \log P_{\mathrm{app}}^{(\mathrm{HPLC})}=1.00( \pm 0.06) \log P_{\text {calc }}-0.17( \pm 0.08) \mathrm{E}_{\mathrm{s}}^{(\mathrm{AMD})}-1.16( \pm 0.18) \\
& \mathrm{n}=28 \quad \mathrm{r}=0.986 \quad \mathrm{~s}=0.184 \quad \mathrm{~F}=421.49 \quad \mathrm{r}^{2} \mathrm{cV}=0.964 \quad \mathrm{~s}_{\text {PRESS }}=0.206
\end{aligned}
$$

Uma estratégia alternativa, para o fato dos compostos da série Ia, se mostraram frente ao sistema biológico, muito mais susceptíveis a hidrólise, dentro do período requerido para o experimento nos levou às séries de análogos estruturais da procainamida, aqui classificadas como séries II, considerando-se que nas mesmas condições, benzamidas apresentam menor grau de hidrólise quando comparadas aos correspondentes benzoatos.

É conhecido na literatura, que a potência anestésica local da procainamida, $(N, N-$ (dimetilamino)etil-4-aminobenzamida) é menor do que a correspondente procaína, (N,N-(dimetilamino)etil-4-aminobenzoato). Estes fatos são explicados, considerando-se a menor lipossolubilidade da procainamida $\left(\log P_{\mathrm{app}}=0.88 ; \mathrm{pK}_{\mathrm{a}}=9.26\right)$ quando comparada a procaína $\left(\log P_{\mathrm{app}}=1.28 ; \mathrm{pK}_{\mathrm{a}} \sim 8.1\right.$. (STRICHARTZ, et al , 1987). Assim, simplesmente alterar a função química desses para amida não seria suficiente, para se conseguir um aumento da potência biológica. Modificações estruturais, que levassem simultaneamente a um aumento da lipofilicidade deveriam, então, ser introduzidas. 
Nesta época, como apresentado em detalhes no memorial, na dissertação de mestrado de Leoberto da Costa Tavares (ANEXO M-2) foi estudada uma série de 8 análogos estruturais da procainamida, contendo somente um grupo metilênico na cadeia intermediária. (Os compostos, na forma de cloretos, foram preparados na dissertação de mestrado, a partir das correspondentes bases livres fornecidas gentilmente por Nilo Zanatta, (ZANATTA, 1993) 1na época estudante do grupo Prof. R. Rittner , UNICAMP, SP.). A série, embora não adequada para uma análise de $Q S A R$, se mostrou promissora quanto a avaliação semi-quantitativa da atividade anestésica local, realizados em nossos laboratórios. Estes compostos demonstraram que a redução do número de grupos metilênicos da cadeia intermediária, conduzia a compostos mais ativos (série IIa), ou seja maior potência anestésica (ANEXO M-2) (ANEXO IX). A tabela II.1.1-2 foi incluída no texto. Os resultados sugeriam um possível efeito da estabilidade do composto bem como de efeitos de proximidade de grupos polares, que estavam modulando (aumentando) a lipofilicidade bem como a atividade anestésica local, quando comparada com a procainamida, embora o número de grupos metilênicos da cadeia intermediária tivesse sido reduzido para um.

Tabela II.1.1-2 Valores da atividade anestésica local máxima relativos à procaína, $\mathrm{AAL}_{\text {max., }}$ de cloretos de $N$-[(dimetilamino)metil]benzamidas 4substituídas.(ANEXO IX)

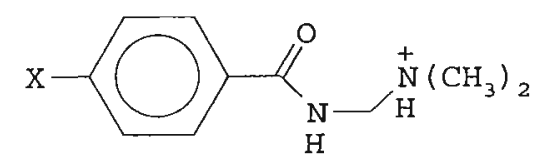

$\left[\mathrm{Cl}^{-}\right]$

\begin{tabular}{lll}
\hline Composto & $\mathbf{X}$ & $\mathbf{A A L}_{\max }$ \\
\hline$\underline{\mathbf{1 b}}$ & $\mathrm{NO}_{2}$ & $0,3 \pm 0,1$ \\
$\underline{\mathbf{2 b}}$ & $\mathrm{Br}$ & $0,9 \pm 0,1$ \\
$\underline{\mathbf{3 b}}$ & $\mathrm{Cl}$ & $0,9 \pm 0,1$ \\
$\underline{\mathbf{4 b}}$ & $\mathrm{I}$ & $0,7 \pm 0,1$ \\
$\underline{\mathbf{5 b}}$ & $\mathrm{F}$ & $0,8 \pm 0,1$ \\
$\underline{\mathbf{6 b}}$ & $\mathrm{H}$ & $0,9 \pm 0,1$ \\
$\underline{\mathbf{8 b}}$ & $\mathrm{OCH}_{3}$ & $1,0 \pm 0,1$ \\
Procaína & $-\cdots$ & 1,0 \\
\hline
\end{tabular}


Deve-se considerar, no entanto, que a avaliação da atividade anestésica local dos compostos da série $\underline{B}$ foi feita empregando-se o método de bloqueio nervoso periférico in vivo. Na época, por uma aproximação, admitiu-se que a solução đo composto a ser analisado é injetada nas proximidades do nervo a ser bloqueado, de forma que a sua biodisponibilidade pode ser considerada, em princípio, semelhante às preparações in vitro. Em primeira análise, fixando-se a dose e admitindo-se que as curvas dose-resposta de compostos análogos sejam paralelas, aceita-se que a resposta máxima obtida seja proporcional à potência. Assim, considerou-se, em uma análise preliminar, que a atividade anestésica local máxima, $\mathrm{AAL}_{\max }$, dos compostos analisados como sendo proporcional à sua potência. Para estes compostos a $\mathrm{AAL}_{\text {max }}$. ocorreu por volta de vinte minutos contados a partir da administração com posterior declínio. Na Tabela II.1.1-2 encontram-se reunidos os valores de atividade anestésica local, $\mathrm{AAL}_{\max }$. relativamente à procaína, para a série de cloridratos de $N$-[(dimetilamino)metil]benzamidas 4substituídas estudada neste trabalho.

Os resultados observados de atividade, embora realizados in vivo e nãoquantitativos, foram importantes para o andamento do trabalho, pois os compostos se mostraram tão ativos quanto à procaína, tomada como referência nas preparações biológicas.

Em nosso laboratório, em vista destes resultados, projetamos, agora de acordo com critérios propostos por Craig (CRAIG, 1971) e, preparamos por métodos descritos na literatura, uma série de 11 benzamidas, contendo somente um grupo metilênico na cadeia intermediária, qual seja, cloretos de $\mathrm{N}$-(dimetilamino)metil-benzamidas, substituídos em para (série II-a).

Determinamos, pelo método shake-flask (VIDE, DISCUSSÃO SOBRE CONDIÇÕES E METODOLOGIAS) os correspondentes valores do coeficiente de partição aparente, $\log P_{\text {app }}$, que incorporam correção para a ionização. De modo análogo ao realizado para os análogos estruturais da procaína (neste texto classificados como séries I), os valores de $\log P_{\text {app }}$ foram validados e, considerados descritores das interações hidrofóbicas e utilizados como parâmetro hidrofóbico, para as análises de QSAR (CAPITULO IHI.1).

Os resultados deste trabalho foram tema da dissertação de mestrado de Yoshinori Myazaki (não finalizada) e retomada, incluindo outros aspectos, no projeto de IC de 
Alberto Malvezzi sendo apresentados em Congressos Nacionais e Internacionais. Os resultados constam de publicações (ANEXO III) (ANEXO V) e de manuscrito em fase de preparação.

Os valores menores de $\log P_{\text {app }}$ observados (média $\sim 0,4$ ) para a série de benzoatos (séries I) quando comparados com a série de benzamidas (média 1,2) (séries IIa), contendo somente um único grupo metilênico na cadeia intermediária, podem ser atribuídos à presença tanto de interações intramoleculares entre o oxigênio carbonílico e o nitrogênio do grupo amina da cadeia lateral bem como às diferenças nas contribuições da porção hidrofilica da molécula para a lipofilicidade da molécula toda, devido às diferenças nos valores de $\mathrm{pK}_{\mathrm{a}}$, com valores (média ) de 7, 4 e 8, 4, respectivamente.

$\mathrm{O}$ efeito (global) foi avaliado incluindo-se a Variável Indicadora, $\mathrm{I}_{(\mathrm{OCOCH} 2)}$, indicando a presença $\left(\mathrm{I}_{(\mathrm{OCOCH} 2)}=1\right)$ ou ausência $\left(\mathrm{I}_{(\mathrm{OCOCH} 2)}=0\right)$ do grupamento $\mathrm{OCOCH}_{2}$, podendo-se desta forma, descrever a lipofilicidade das duas séries (séries I e II) em uma único modelo, expresso pela equação II.1.1-6.

$\log P_{\text {app }}{ }^{(\mathrm{SF})}=0.84( \pm 0.11) \log P_{\text {calc }}-0.49( \pm 0.29)$

II.1.1-5

$\mathrm{n}=26 \quad \mathrm{r}=0.957 \quad \mathrm{~s}=0.343 \quad \mathrm{~F}=259.91 \quad \mathrm{r}^{2} \mathrm{cv} \quad \mathrm{S}_{\text {PRESS }}$

$\log P_{\text {app }}{ }^{(\mathrm{SF})}=1.00( \pm 0.04) \log P_{\text {calc }}-0.77( \pm 0.10) \mathrm{I}_{\mathrm{OCOCH}_{2}}-0.387( \pm 0.08)$

II.1.1-6

$\mathrm{n}=26 \quad \mathrm{r}=0.997 \quad \mathrm{~s}=0.098 \quad \mathrm{~F}=1726.7 \quad \mathrm{r}^{2} \mathrm{cv}=\quad$ SPRESS $=$

A contribuição destes efeitos para a lipofilicidade pode ser avaliada através do valor do coeficiente de regressão associado à Variável Indicadora $(-0,77)$. O valor do coeficiente de regressão do termo $\log P$, ao se introduzir a Variável Indicadora na análise, torna-se próximo a unidade (0.997), como observado na equação II.1.1-6.

Este(s) efeito(s) de natureza intramolecular, explicam os maiores valores de $\log P_{\text {app }}$ observados para a série de benzamidas quando comparados aos correspondentes benzoatos. Efeito similar pode ser observado na comparação com os valores de $\log P$, calculados pelo programa CLOGP, que não considera a carga positiva no nitrogênio quartenário.

Como relatado em detalhes no memorial, a impossibilidade de continuar os estudos utilizando $\mathrm{LD}_{50}$ como parâmetro biológico, nos fez interromper - do ponto de 
vista metodológico - a análise dos resultados como havíamos inicialmente planejado. Desta forma, para as séries subseqüentes, séries IIIa, foram realizadas as determinações da atividade bloqueadora neuromuscular, avaliadas em preparações neuromusculares de camundongos.

Neste contexto, é importante ressaltar, a importância da frutífera colaboração com o grupo de pesquisadores liderados pelo Prof. Dr. Antônio José Lapa, no Departamento de Farmacologia da Universidade Federal de São Paulo (UNIFESP) (vide comentário específico no memorial), onde as determinações foram realizadas.

De uma forma geral, a presença de um grupo cationico parece ser uma característica estrutural necessária para a inibição não-competitiva dos receptores nicotínicos. Várias aminas não quaternárias que se encontram em grande parte ionizadas em pH fisiológico, como por exemplo, quinina, nicotina bloqueiam receptores nicotínicos da acetilcolina na junção neuromuscular. No entanto, os seus respectivos análogos, sais quaternários de amônio, apresentam-se mais potentes (WESS, 1990) Neste sentido, Albuquerque e colaboradores (IKEDA, 1984) em um de seus trabalhos, no qual tinham como objetivo estudar as interações da bupivacaína, anestésico local, com canais iônicos do receptor nicotínico, observaram que a introdução de grupo metila na cadeia lateral da bupivacaína, levando à formação do grupamento catiônico, contendo um átomo de nitrogênio quaternário, causa um aumento na potência inibitória, avaliada em preparações de músculo sartório-nervo ciático de rãs. (

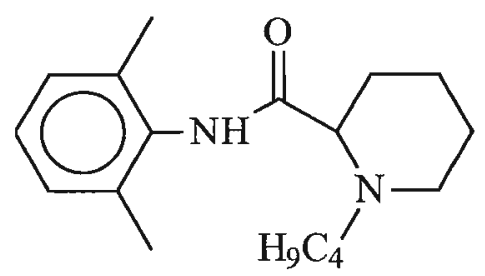

Estrutura da bupivacaína.

Ainda mais, foi observado que a densidade de carga no grupo catiônico, também afeta a potência de bloqueio dos receptores nicotínicos. Não menos importante, a lipofilicidade também exerce influência sobre a atividade bloqueadora neuromusculares. Segundo a literatura (STENLAKE, 1981) a potência de agentes bloqueadores neuromusculares é aumentada quando substituintes lipofilicos estão próximos ou 
diretamente ligados no grupo amônio. Recentemente, Bixel e colaboradores (BLXEL, 2000) estudaram a relação entre a estrutura e atividade e o sítio de ligação de uma série de 14 poliaminas análogas da philantoxina atuando como inibidores não competitivos dos receptores nicotínicos da acetilcolina, avaliados pelas constantes de ligação dos compostos com o receptor nicotínico. Neste trabalho, os autores puderam observar que aumentando o tamanho da cabeça hidrofóbica, introduzindo grupos aromáticos volumosos ocorria um aumento da afinidade pelo receptor quando comparada com a philantoxina.

Os autores explicaram estes resultados, assumindo que a hidrofobicidade da cabeça hidrofóbica é uma característica estrutural importante para a excepcional afinidade pelo receptor nicotínico. Neste trabalho, no entanto, a lipofilicidade não foi determinada ou mesmo calculada. Além disso, os mesmos autores propõem que estes compostos exercem a atividade de inibição pelo mecanismo estérico, pois foi sugerido que tanto a philantoxina como as poliaminas entram no canal iônico do receptor vindos do meio extracelular, as cabeças hidrofóbicas se ligam ao sítio de alta afinidade enquanto que as cadeias laterais contendo carga positiva provavelmente interagem com as cadeias laterais de aminoácidos carregados negativamente projetados para o lúmen do canal. Outros fatores como ligação de van der Waals e fatores estéricos também são propostos como importantes para a interação do antagonista ao receptor (WESS, $1990 \mathrm{E}$ STENLAKE, 1981).

Baseados nestes trabalhos $e$, como já referido, com a colaboração do grupo professor Lapa, tornou-se de interesse avaliar a lipofilicidade de compostos contendo este grupamento catiônico.

Assim, mais recentemente, preparamos e estudamos série (IIIa) de onze brometos de [2-(4-X-benzamido)etil]benzildimetilamônio, compostos IIIa.1 a IIIa.11, estruturalmente análogos à procainamida, compostos não descritos na literatura, atuando como bloqueadores neuromusculares, ou seja, antagonistas não competitivos de receptores nicotínicos musculares. Estes estudos foram tema da dissertação de mestrado de Leonardo Amaral de Siqueira (ANEXO M-7).

A partir das metodologias implementadas no laboratório, procedendo-se, de modo análogo, determinando-se os valores do coeficiente de partição, $\log P_{\text {app }}{ }^{7,40}$, desta série 
de compostos pelo método shake-flask e foram utilizados como parâmetro lipofílico experimental em análise $Q S A R$.. Os valores obtidos esão apresentados na Tabela II.1.1-3.

Tabela II.1.1-3. Valores do coeficiente de partição respectivamente, obtidos por calculo (log $\left.P_{\text {calc }}\right)$ e determinados experimentalmente, $\left(\log \mathrm{P}_{\text {app }}{ }^{7,40}\right)$ bem como da constante de substituinte hidrofóbica, $\pi$, retirados da literatura e $\pi_{\exp }$ para a série de brometos de [2-(4-X-benzamido)etil]benzildimetilamônio substituídos, compostos IIa.1 a IIa.11.

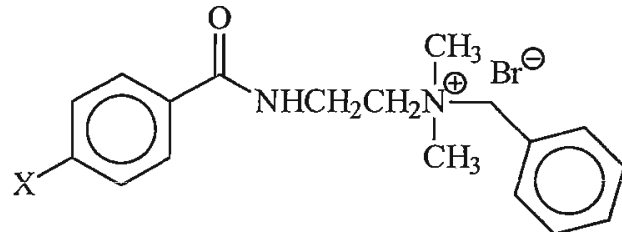

\begin{tabular}{|c|c|c|c|c|c|c|}
\hline Composto & 4-X & $\log P_{\text {calc }}{ }^{(a)}$ & $\log \mathbf{P}_{\mathrm{app}}{ }^{7,40(\mathrm{~b})}$ & $\Delta^{(\mathrm{c})}$ & $\pi$ & $\pi_{\text {exp }}{ }^{(d)}$ \\
\hline IIIa.1 & $\mathrm{H}$ & 4.88 & $-0,38( \pm 0,02)$ & 5,26 & 0,00 & 0,00 \\
\hline IIIa.2 & $\mathrm{CH}_{3}$ & 5,38 & $0,23( \pm 0,02)$ & 5,15 & 0,56 & 0,61 \\
\hline IIIa.3 & $n-\mathrm{C}_{4} \mathrm{H}_{9}$ & 6,97 & $1,87( \pm 0,01)$ & 5,10 & 2,13 & 2,25 \\
\hline IIIa.4 & $n-\mathrm{C}_{6} \mathrm{H}_{13}$ & 8,02 & $2,76( \pm 0,07)$ & 5,26 & 3,10 & 3,14 \\
\hline ШШа.5 & $\mathrm{OCH}_{3}$ & 5,08 & $-0,07( \pm 0,01)$ & 5,15 & $-0,02$ & 0,31 \\
\hline IIIa.6 & $\mathrm{Cl}$ & 5,79 & $0,54( \pm 0,04)$ & 5,26 & 0,71 & 0,92 \\
\hline IIIa.7 & $\mathrm{Br}$ & 5,94 & $0,73( \pm 0,04)$ & 5,21 & 0,86 & 1,11 \\
\hline ШІа.8 & $\mathrm{NO}_{2}$ & 5,05 & $-0,24( \pm 0,06)$ & 5,29 & $-0,28$ & 0,14 \\
\hline IIIa.9 & $\mathrm{CN}$ & 4,78 & $-0,56( \pm 0,06)$ & 5,34 & $-0,57$ & $-0,18$ \\
\hline IIIa.10 & $\mathrm{CF}_{3}$ & 6,12 & $0,68( \pm 0,04)$ & 5,44 & 0,88 & 1,06 \\
\hline IIIa.11 & $\mathrm{SO}_{2} \mathrm{CH}_{3}$ & 3,89 & $-1,63( \pm 0,01)$ & 5,53 & $-1,63$ & $-1,25$ \\
\hline
\end{tabular}

(a) Valores obtidos pelo programa CLOGP, Versão 1.0.0, BioByte, USA.

(b) Valores determinados em duplicata e seu desvio padrão apresentado entre parênteses. Estes foram obtidos pelo método shakeflask, tampão Trizma, $\mathrm{pH}=7,40, \mu=0,10 \mathrm{M}(\mathrm{KCl})$, e na faixa de concentrações entre $1 \times 10^{-4}-1 \times 10^{-5} \mathrm{~mol} / \mathrm{L}$.

(c) $\Delta=\log \mathrm{P}_{\text {calc }}-\log \mathrm{P}_{\text {app }}{ }^{7,40}$.

(d) Valores obtidos a partir da equação: $\pi_{\mathrm{exp}}=\left(\log \mathrm{P}_{\mathrm{app}}^{7,40}\right)_{\mathrm{X}}-\left(\log \mathrm{P}_{\mathrm{app}}^{7,40}\right)_{\mathrm{H}}$.

As Figuras II.1.1-5 e II.1.1-6 apresentam as correlações obtidas entre valores de $\log P_{\text {app }}{ }^{7,40}$ determinados experimentalmente em função de parâmetros, respectivamente, retirados da literatura e obtidos por cálculo. 


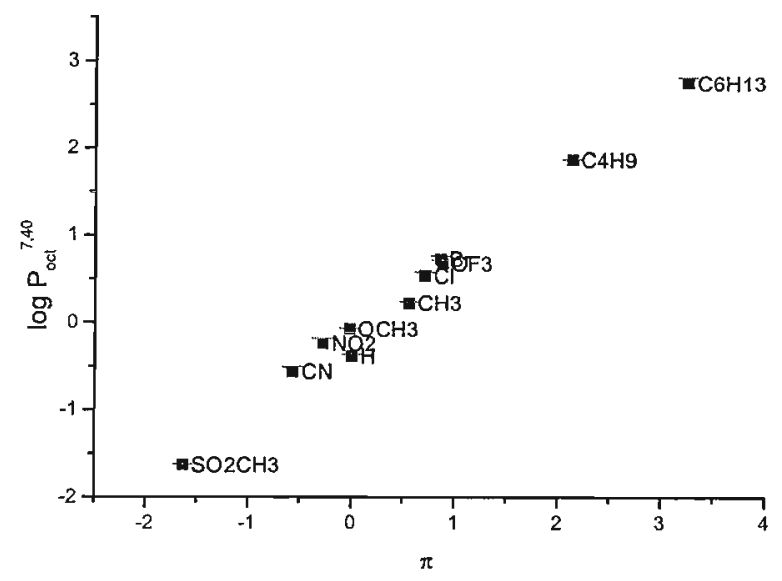

$\log P_{a p p}^{7,40}=0,92( \pm 0,06) \pi+0,12( \pm 0,09)$

$n=11 ; r=0,995 ; s=0,12 ; \quad F=947.33 ; Q^{2}=0,99 ; s_{\text {PRESS }}=0,14$

Figura II.1.1-2. Correlação obtida entre os valores de $\log P_{\text {app }}{ }^{7,40}$ e de $\pi$ para a série de brometos de [2-(4-X-benzamido)etil]benzildimetilamônio substituídos, série IIIa

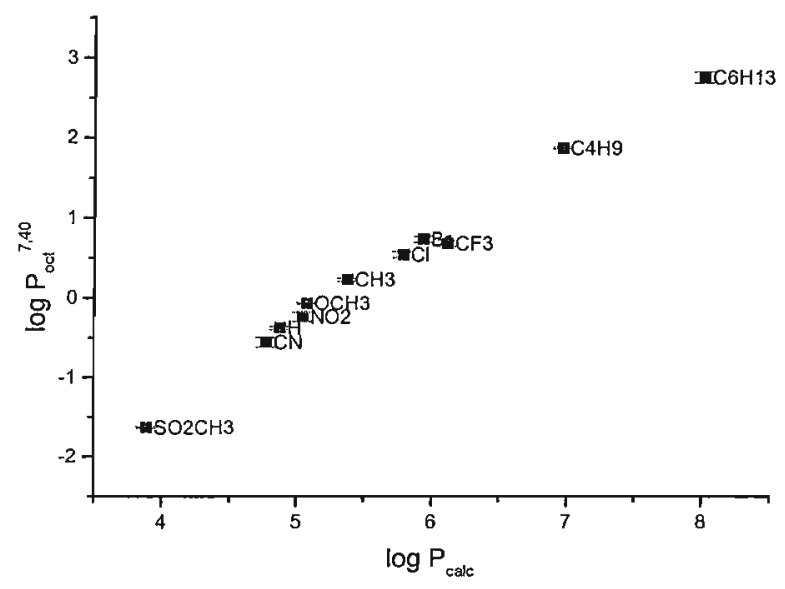

$\log P_{\text {app }}^{7,40}=1,05( \pm 0,11) \log P_{\text {calc }}-5,53( \pm 0,62)$

$n=11 ; r=0,995 ; s=0,12 ; F=966,06 ; Q^{2}=0,98 ; s_{\text {PRESS }}=0,16$

Figura II.1.1-3. Correlação obtida entre os valores de $\log P_{\text {app }}{ }^{7,40}$ e de $\log P_{\text {calc, para }}$ a série de brometos de [2-(4-X-benzamido)etil]benzildimetilamônio substituídos, compostos III.a.1-IIIa.11.

As correlações significativas observadas entre os valores de $\log P_{\text {app }}$ tanto com os valores de $\log \mathrm{P}_{\text {calc }}$ como de $\pi$, juntamente com os valores dos coeficientes de regressão das respectivas equações, com valores próximos da unidade $(\sim 1)$ revelam que o princípio de aditividade, nesta série é mantido e sugerem ainda que interação(ões) 
intramolecular(es) específica(s) para determinado grupo substituinte não é(são) observada(s).

Sendo assim, demontramos que para a série estudada (IIIa), contendo dois grupos metilênicos na cadeia intermediária, a contribuição hidrofóbica do grupamento catiônico terminal para o valor do coeficiente de partição permaneceu constante, dentro do erro experimental.

Adicionalmente, neste trabalho, que foi tema da dissertação de mestrado de Leonardo Amaral de Siqueira (ANEXO M-7) e, de manuscrito em fase de preparação, demonstramos haver correlação significativa entre a atividade de bloqueio da transmissão neuromuscular (expressa por $\mathrm{pIC}_{50}$ ) e os respectivos parâmetros lipofílicos (expressos, por $\pi, \log P_{\text {app }} \mathrm{SF}(p H 7,4)$ e por $\log P_{\text {calc }}$ ) Estes resultados confirmaram tanto a importância da presença do grupo catiônico terminal como da lipofilicidade do compostos para o bloqueio da transmissão neuromuscular. (CAPÍTULO III.1)

Outro aspecto bastante importante, por nós também estudado, se baseou no fato de que muitas das moléculas com ação terapêutica encontram-se parcialmente ionizadas no sistema biológico e, portanto suas lipofilicidades são significativamente afetadas pelas estabilidades relativas de cada espécie - ionizada e não-ionizada - nos diferentes compartimentos. Ou seja, como já apresentado anteriormente neste texto, (Figura I.1.11 ) a distribuição do composto através dos diferentes compartimentos é determinada pelos diversos equilíbrios simultâneos estabelecidos entre as fases e entre as espécies (SCHERRER, 2001).

Em outras palavras, o valor do coeficiente de partição aparente, $\log P_{\text {app}}$, (AMARAL, MIYAZAKI, CAPOBIANCO et al., 1991; KUBINYI, 1993; AMARAL, OLIVEIRA, NEIDLEIN et al.,1997) de um composto contendo grupo ionizável, varia com o pH, determinando muitas vezes a resposta biológica (KUBINYI, 1993). Desta forma, para estes compostos torna-se bastante importante e informativo, o estudo do perfil de $\log P_{\text {app }}$ versus pH (SCHERRER, 1996; SCHERRER, 2001, MALVEZZI et al., 2001, Malvezzi, 2003).

Exemplificando, a Figura II.1.1-4 apresenta a representação esquemática do perfil de $\log P_{a p p}$ em função do $\mathrm{pH}$ de uma base fraca hipotética onde estão identificados no gráfico os termos $\log P_{n}, \log P_{i} ; p K_{a}{ }_{\text {água }}$; e $p K_{a}^{\text {octanol }}$ respectivamente (COMER \& TAM, 2001): 


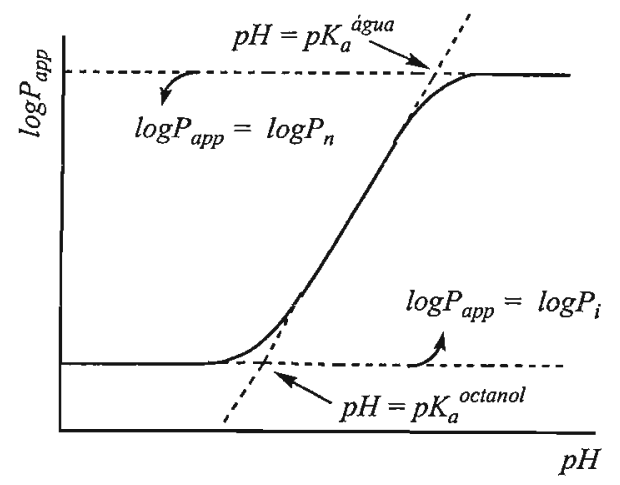

\section{Figura I1.1.1-4 . Representação esquemática do perfil de variação dos valores de $\log P_{a p p}$ de uma base fraca em função dos valores de $\mathrm{pH}$ (COMER \& TAM, 2001)}

A equação II.1.1-4 descreve o valor do $\log P_{a p p}$ de uma base em função, respectivamente, dos valores de $\mathrm{pH}$, do $\log P_{\mathrm{n}}$ do $\log P_{\mathrm{i}} \mathrm{e}$ do $p K_{a}^{\text {água }}$ (COMER \& TAM, 2001; KUBINYI, 1993)

$$
\log P_{a p p}=\log \left(P_{n} \cdot 10^{p H}+P_{i} \cdot 10^{p K a}\right)-\log \left(10^{p K a}+10^{p H}\right) \quad \text { (equação II.1.1-7) }
$$

onde:

$\log P_{a p p}$ é o valor do logarítimo do coeficiente de partição aparente do composto $\operatorname{logo}_{n} P_{n}$ é o valor do logarítimo coeficiente de partição da espécie não-ionizada $\log P_{i}$ é o valor do logarítimo coeficiente de partição da espécie ionizada $K_{a}$ é o valor da constante de ionização do composto

Os valores de $\log P_{a p p}$ são utilizados em análises de $Q S A R$ para descrever processos de absorção e de transporte de compostos ionizáveis através de membranas (; SCHERRER, 2001). Os valores de $\log P_{a p p}$, no entanto, não devem ser usados para descrever os equilíbrios envolvidos na interação de equilíbrio da interação entre o ligante e o receptor (KUBINYI, 1993). Nesses casos, devem ser usados os valores dos coeficientes de partição correspondentes somente à espécie responsável pela atividade, seja ela a espécie ionizada $\left(\log P_{\mathrm{i}}\right)$ ou a espécie não-ionizada $\left(\log P_{\mathrm{n}}\right)($ SCHERRER, 2001 ), podendo ser obtidos diretamente a partir dos valores de $\log P_{a p p}$, como indicado na Figura II.1.1-4.

Com base nestes trabalhos e dos resultados obtidos na dissertação de mestrado de Leonardo Siqueira (ANEXO M-7) e considerando-se a importância do estudo das 
propriedades de $\mathrm{ADME}$ no planejamento racional de novos fármacos, ou mais especificamente, de moléculas candidatas a fármacos (MALVEZZI et al., 2001; SCHERRER, 2001) decidimos iniciar os estudos dos efeitos da variação de estrutura sobre os parâmetros hidrofóbicos, de uma série de derivados da procaína, agora avaliados quanto a sua potencial atividade de inibição da transmissão neuromuscular (expressa por $\mathrm{pIC}_{50}$ ).

Desta forma, na dissertação de mestrado de Alberto Malvezzi, (ANEXO M-8), dentre outros aspectos, procuramos descrever as interações hidrofóbicas determinantes da atividade bloqueadora neuromuscular potencial, para uma série planejada de dez derivados da procaína, estruturalmente diversos, na qual se introduziram modificações na circunvizinhanças do grupo amina terminal e na cadeia lateral (Figura II.1.1-5).

\begin{tabular}{|c|c|c|c|c|c|}
\hline \multirow{11}{*}{ 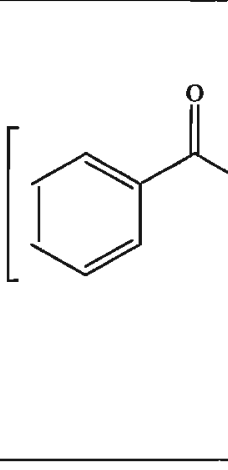 } & \multirow{11}{*}{$\mathrm{Cl}^{-}$} & No & $\mathbf{X}$ & $\mathbf{n}$ & $\mathbf{Y}$ \\
\hline & & Imb.1 & $-\mathrm{CH}_{2-}$ & 1 & $-\mathrm{N}\left(\mathrm{CH}_{3}\right)_{2}$ \\
\hline & & IIb.2 & $-\mathrm{CH}_{2}-$ & 1 & $-\mathrm{N}\left(\mathrm{C}_{2} \mathrm{H}_{5}\right)_{2}$ \\
\hline & & $\underline{\text { IIIb.3. }}$ & $-\mathrm{CH}_{2}-$ & 1 & -Pirrolidino \\
\hline & & IIb.4 & $-\mathrm{CH}_{2}-$ & 1 & -Piperidino \\
\hline & & IIIb.5 & $-\mathrm{CH}_{2-}$ & 1 & -Morfolino \\
\hline & & IIb.6 & $-\mathrm{CH}_{2}-$ & 1 & -Piperazino \\
\hline & & IIb.7 & $-\mathrm{CH}_{2-}^{-}$ & 1 & $-c$-hexilamino \\
\hline & & IIIb.8 & $-\mathrm{NH}-$ & 2 & $-\mathrm{N}\left(\mathrm{CH}_{3}\right)_{2}$ \\
\hline & & IIb.9 & - NH- & 1 & $-\mathrm{N}\left(\mathrm{CH}_{3}\right)_{2}$ \\
\hline & & IIIb.10 & $-\mathrm{O}-$ & 2 & $-\mathrm{N}\left(\mathrm{CH}_{3}\right)_{2}$ \\
\hline
\end{tabular}

Figura II.1.1-5: Estrutura fundamental da série de derivados da procaína, com potencial atividade inibidora da transmissão do impulso nervoso.

Para cada composto da série (compostos IIIb.1 a IIIb.10), a partir dos valores de $\log P_{a p p} S F$ obtidos em diversos valores de $\mathrm{pH}$, tipicamente de 3,0 a 10,0 , constrói-se o perfil $\log P_{a p p}$ versus $\mathrm{pH}$. Os gráficos com os perfis $\log P_{a p p} S F$ versus $\mathrm{pH}$, determinados para cada composto da série de derivados da procaína (compostos IIIb.1 a IIIb.10), estão tipicamente representado na Figura II.1.1-6. 


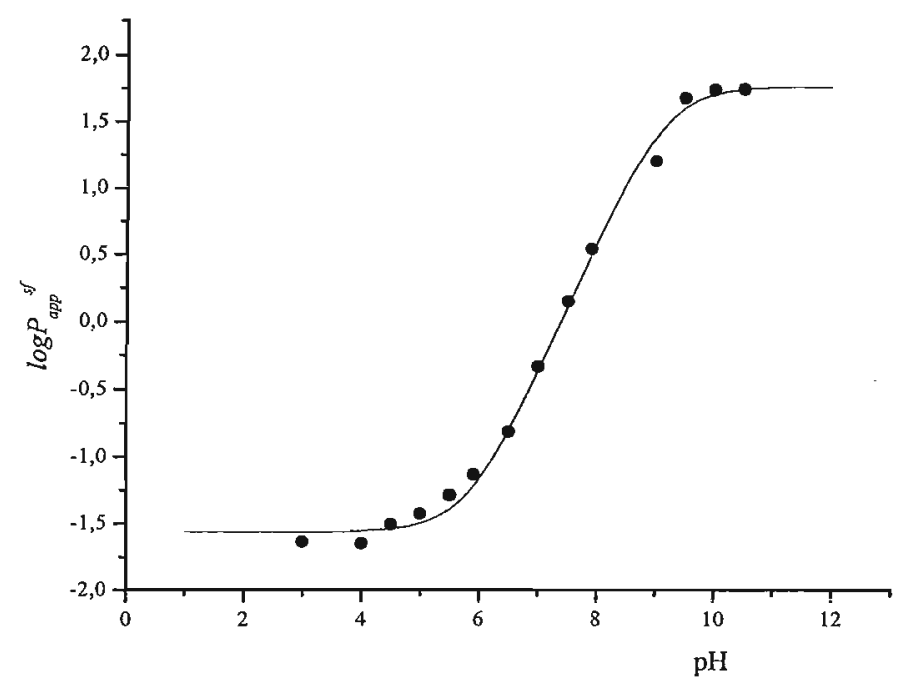

Figura II.1.1-6. Gráfico do perfil $\log P_{a p p}$ vs. pH obtido através dos ajustes ${ }^{(a)}$ dos parâmetros da (equação II.1.1-7)aos valores ${ }^{(b)} \operatorname{de~} \log P_{a p p} S F(\bullet)$ do cloreto de 3-(1-metil)propiofenona (composto IIb.1)

(a) O ajuste dos parâmetros foi feito usando-se a opção "non linear curve fitting" do programa Origin6.0 (OriginLab® Corporation (C) 1991-2002) e,

(b) Obtidos pelo método shake-flask, usando n-octanol/tampão, $\mu=0.10 \mathrm{M}(\mathrm{NaCl})$ e à $23 \pm 1{ }^{\circ} \mathrm{C}$.

Para cada composto da série, do correspondente gráfico do perfil $\log P_{a p p}{ }^{S F}$ versus $\mathrm{pH}$ foram obtidos graficamente os respectivos valores das constantes de ionização na fase aquosa $\left(p K_{a}^{\mathrm{aq}}\right)$ e, em n-octanol $\left(p K_{a}{ }^{\text {oct }}\right)$ e, os valores do coeficiente de partição das espécies ionizada $\left(\log P_{\mathrm{i}}\right)$ e, não ionizada $\left(\log P_{\mathrm{n}}\right)$. Estes quatro termos, quais sejam: $p K_{a}^{\text {aq }}, p K_{a}^{\text {oct }}, \log P_{\mathrm{n}}$ e, $\log P_{\mathrm{i}}$ descrevem os quatro equilíbrios presentes no modelo de partição de moléculas ionizadas Figura II.1.1-1 (COMER \& TAM, 2001). 


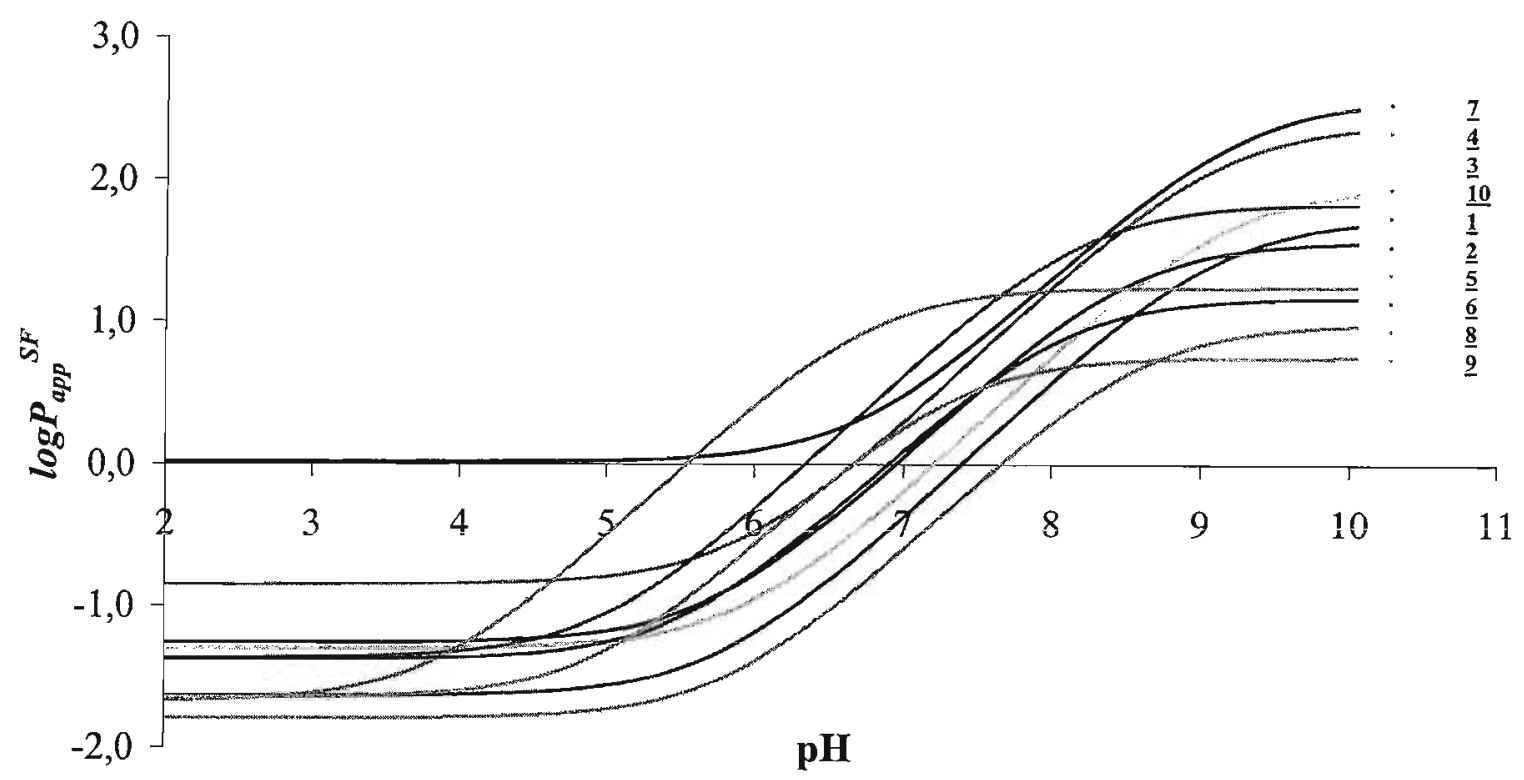

Figura II.1.1-7.Gráfico dos perfis de $\log P_{a p p}$ vs. pH determinados através do ajuste $^{(a)}$ dos valores ${ }^{(b)}$ de $\log P_{a p p}{ }^{S F}$ aos parâmetros da equação II.1.1-7 para a série de derivados da procaína (compostos IIIb.1 a IIb.10).

a $\mathrm{O}$ ajuste dos parâmetros foi feito usando-se a opção "non linear curve fitting" do programa Origin6.0 (OriginLab® Corporation (C) 1991-2002).

${ }^{b}$ Obtidos pelo método Shake-flask, usando $n$-octanol/tampão, $\mu=0,10 \mathrm{M}(\mathrm{NaCl})$ e a $23 \pm 1{ }^{\circ} \mathrm{C}$.

Pelos gráficos de perfis traçados, Figura II.1.1-7 (ANEXO M-8) observa-se que em valores de $\mathrm{pH}$ menores do que 4,0 o cloreto de 3-(1-morfolino)propiofenona

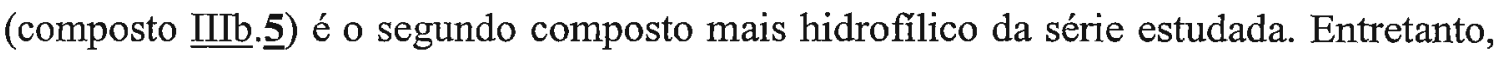
em valores de $\mathrm{pH}$ na faixa de 5,5 a 7,5, o composto ஹl 5 passa a ser o composto mais lipofílico da série e, em valores de $\mathrm{pH}$ maiores que 8,0 o composto IIIb $\underline{\mathbf{5}}$, volta a ser um dos compostos mais hidrofílicos dentro da série de derivados da procaína. Estas variações relativas de lipofilicidade dentro da série são observadas para todos os outros compostos e podem ser atribuídas principalmente às diferenças nos correspondentes valores de $\mathrm{pK}_{\mathrm{a}}$, provenientes do grupamento amino, ou seja, considerando-se novamente o exemplo do cloreto de 3-(1-morfolino)propiofenona (composto 피 5), este apresenta, na série estudada, o menor valor de $\mathrm{pK}_{\mathrm{a}}\left(\mathrm{pK}_{\mathrm{a}}^{\mathrm{aq}}=6,8\right)$.

Assim, para o composto $\underline{\mathbf{5}}$ a concentração relativa da espécie não ionizada $(B)$ é significativamente maior do que da espécie ionizada $\left(B H^{+}\right)$, para valores de $\mathrm{pH}$, nos 
quais todos os outros compostos da série, já se encontram parcialmente ionizados. Como conseqüência, na faixa de valores de $\mathrm{pH}$ entre 5,5 a 7,5, observa-se maior lipofilicidade aparente $\left(\log P_{a p p}\right)$ para o composto $\underline{\mathbf{5}}$, descrita por $\log P_{a p p}$, quando comparada com as lipofilicidades aparentes correspondentes aos outros compostos da série.

Desta forma, demostramos, na série estudada, a importância da determinação experimental do coeficiente de partição em uma ampla faixa de $\mathrm{pH}$, bem como dos termos relacionados ionização, aspecto nem sempre considerado, na literatura, em especial para compostos bioativos.

\section{$\underline{\text { Algumas consideracões sobre as metodologias empregadas }}$}

Para que o modelo proposto (aspecto que será posteriormente discutido) pela análise de $Q S A R$ seja estatisticamente válido e de interesse, recomenda-se selecionar séries de compostos que apresentem amplos espectros de variação tanto dos parâmetros estruturais (em especial os relacionados com a lipossolubilidade, idealmente 4 a 5 unidades em escala logarítmica) bem como dos parâmetros biológicos. Deste modo, considerando os erros sistemáticos intriínscicos de cada metodologia, para que as incertezas nos valores dos parâmetros sejam mantidas em todo intervalo analisado os procedimentos experimentais para aquisição dos dados devem ser otimizados, e, os parâmetros validados. Este aspecto está sendo observado em nosso laboratório e, implementado, na medida do possível, em todos os projetos desenvolvidos (vide comentários específicos no memorial).

Como discutido em diversos pontos deste texto, a observação de variações nos valores de $\log P$, podem revelar tanto mudanças introduzidas (de naturezas estérica e/ou eletrônica) na estrutura de um soluto bem como efeitos de interações de naturezas intrae/ou intermoleculares, que podem afetar a lipofilicidade do composto. Além destas, a metodologia empregada e/ou as condições experimentais empregadas igualmente podem acarretar diferenças significativas, dentro do erro experimental, nos valores medidos de $\log P$. A análise destas diferenças pode revelar, muitas vezes, informação sobre a(s) natureza(s) da(s) interação(ões) inter- e intramoleculares presentes no sistema estudado. 
Diferentes métodos têm sido descritos para a determinação experimental (AMARAL et al., 1997; PIRES, SAITO, AMARAL, 2000; AVDEEF, 1993) ou o cálculo de $\log P$ (LEO, 1993), entre eles:

\section{Método shake-flask (Método do frasco agitado)}

Entre os métodos experimentais, o mais reconhecido é o método "shake-flask", revisado na literatura (DEARDEN; BRESNEN, 1988). Neste método, direto, o composto é deixado particionar entre as duas fases mutuamente pré-saturadas. Depois de atingido o equilíbrio, a concentração do composto é determinada, preferencialmente em ambas as fases, por um método analítico adequado. O planejamento do experimento, envolve tanto a escolha das condições analíticas adequadas bem como a concentração mínima necessária na partição. Este procedimento visa assegurar a reprodutibilidade das medidas. Outros fatores a serem considerados foram revisados na literatura (DEARDEN; BRESNEN, 1988). A determinação experimental dos valores de $(P)$, pelo método shake-flask é a princípio um procedimento simples. Entretanto, por se tratar da determinação da razão de concentrações em equilíbrio, fatores como temperatura, forçaiônica, $\mathrm{pH}$, concentração do soluto, natureza do contra-íon, tempo de agitação, présaturação das fases, separação das fases, volume das fases e pureza dos solutos podem influenciar o valor do $\log P$ obtido e devem ser controlados. Neste artigo, Dearden e Bresnem alertaram ainda, para o fato de que, na literatura, o mesmo composto pode apresentar diferentes valores de $\log P$, e classificaram como aceitáveis variações de até 0,3 unidades de $\log P$ para um mesmo composto.

\section{Métodos envolvendo técnicas cromátográficas. $(R P-H P L C)$}

O parâmetro hidrofóbico $\log P$ pode ser obtido, indiretamente, a partir do tempo de retenção de um soluto em um sistema cromatográfico (AMARAL et al., 1997; KLEIN, et al., 1988). Para tanto, as fases estacionária e a móvel do sistema cromatográfico devem reproduzir as interações do soluto, quando este se particiona em um sistema bifásico (líquido-líquido; $n$-octanol/água).

Técnicas cromatográficas em coluna de fase reversa têm sido cada vez mais usadas (Reverse Phase-High Performance Liquid Chromatography, RP-HPLC) (; UNGER, COOK, HOLLENBERG, 1978; UNGER, CHIANG, 1981; KLEIN, KÖRDEL, WEISS et al., 1988; Amaral, et al, 1995; AMARAL, OLIVEIRA, 
NEIDLEIN et al., 1997; PIRES, 2001; RANDO et al; 2002), devido à relativa facilidade de execução, incluindo-se automação.

$\mathrm{O}$ princípio deste método é que os valores do fator de capacidade $\left(\mathrm{k}^{\prime}\right)$ de compostos determinados em um sistema cromatográfico estão relacionados com a partição destas substâncias entre a fase móvel (eluente) e a fase estacionária (material da coluna), sendo k' definido pela equação II.1.1-8.

$$
\mathbf{k}^{\prime}=\left(\mathbf{V}-\mathbf{V}_{\mathbf{0}}\right) / \mathbf{V}_{\mathbf{0}}
$$
sendo:

\section{equação II.1.1-8}

V : volume de retenção para o composto que está sendo medido;

$\mathbf{V}_{\mathbf{0}}$ : volume de retenção de uma substância que não interage com a fase estacionária.

Os valores de $\log \mathbf{k}^{\prime}$ se correlacionam com os valores de $\log \boldsymbol{P}_{\text {oct }}$ através da equação II.1.1-9.

$$
\log P=\mathbf{a} \log \mathrm{k}^{\prime}+\mathrm{b}
$$

equação II.1.1-9

Os valores das constantes a e b são calculados para o sistema cromatográfico em questão pela determinação de $\log \mathbf{k}^{\prime}$ para substâncias padrão, com valores de $\log \boldsymbol{P}_{\text {oct }}$ conhecidos na literatura. Entre as vantagens deste último método podem-se citar: rapidez, aplicabilidade a compostos com $\log \boldsymbol{P}$ bastante altos, aplicabilidade para compostos sem alto grau de pureza. Uma das limitações do método é a necessidade de se dispor de grupo de substâncias padrão, com valores do coeficiente de partição $n$ octanol/água conhecidos para calibração do sistema cromatográfico e, ainda apresentando mecanismos de interação fase móvel/fase estacionária, semelhantes.

\section{Método de obtenção por cálculo}

Métodos para o cálculo de $\log \boldsymbol{P}$ foram revisados na literatura (LEO, 1993). Especial atenção especial é dada ao programa CLOGP, Pomona College, pois o programa CLOGP permite o cálculo de valores de $\log P$ empregando-se fragmentos baseados em banco de dados com milhares de valores experimentais de $\log \boldsymbol{P}$. Correções para interação entre grupos polares próximos também são aplicadas. O programa CILOGP considera somente a contribuição da forma não-ionizada dos compostos para a lipofilicidade total da molécula. Assim, os valores de $\log \boldsymbol{P}_{\text {calc }}$ obtidos se referem a 
partição do composto no sistema octanol/água e não incluem a contribuição de fragmentos contendo grupamentos ionizáveis.

Em relação as metodologias utilizadas no laboratório, além de implementarmos no grupo, fato que resultou em publicações, dissertações de mestrado e teses de doutorado merece destaque nossa contribuição para o banco de dados de reconhecido mérito científico internacionalmente.

Assim, os valores do coeficiente de partição da série de derivados do nitrofurano 5-substituídos, série IV, determinados no laboratório por José Ricardo Murari Pires (ANEXO VI) - em sua tese de doutorado (ANEXO D-II) foram incluídos no banco de dados do grupo de A.Leo (Pomona College, Estados Unidos). Esse banco de dados reune milhares de valores do coeficiente de partição de moléculas, a partir dos quais gerados fragmentos, que são utilizados pelo programa CLOGP. Este fato, a meu ver, reflete um reconhecimento da qualidade de nossos resultados além de ter contribuído com um valor de fragmento, ainda não determinado na literatura. Recebemos, por cortesia, o programa do professor A. Leo, Pomona College, mesmo grupo do renomado Prof. Corwin Hansch. A partir deste fato, e de posse do programa CLOGP, os planejamentos dos experimentos que inicialmente eram feitos, gentilmente pelo professor H.Kubinyi, na BASF-Ludwigshafen, Alemanha, passaram a ser feitos no laboratório.

Ao mesmo tempo, no laboratório desenvolvemos e otimizamos as condições de trabalho experimentais para obtenção dos valores do coeficiente de partição, visando realizar as determinações do coeficiente de partição, para outros grupos de pesquisa do Brasil e do exterior. Destas colaborações resultaram algumas publicações e vários agradecimentos em teses. (vide detalhes no memorial). (ANEXO XII) (DOC.9.3.2.1-21) (DOC 9.3.6.1-51).

\section{$\underline{\text { Algumas consideracões sobre sistemas de particão }}$}

As vantagens do uso de n-octanol como solvente são citadas já nos primeiros trabalhos de Hansch. Até hoje, no entanto, é um bom modelo para membranas biológicas, sob o ponto de vista estrutural, além de apresentar inúmeras outras vantagens comparadas com outros sistemas, amplamente discutidas na literatura (HANSCH, 1990; HANSCH et al., 1995; KUBINYI, 1993 e KUBINYI, 1979). 
Entretanto, a escolha de n-octanol/água como sistema padrão como modelo para a partição precisa ainda ser revista (KUBINYI, 1993).

Desde o trabalho pioneiro de Collander (1951), existe um grande interesse em relacionar o coeficiente de partição medido em diferentes sistemas, em especial em octanol-água, com a estrutura química de determinado composto. Uma primeira abordagem nesta direção é expressar os coeficientes de partição em termos de contribuições de substituintes ou, de fragmentos e, das interações intramoleculares ( HANSCH et al., 1995). Embora seja muito útil para o cálculo e a previsão de valores de $\log P$, estas abordagens tem valor limitado, não revelando informações sobre as interações intermoleculares envolvidas, ou "codificadas", no coeficiente de partição. Entretanto, são estas interações intermoleculares que governam o reconhecimento do fármaco para interagir com o alvo biológico, explicando muitas das correlações observadas entre lipofilicidade e atividade biológica.

Das abordagens descritas na literatura as mais importantes, no entanto, fornecem informações sobre a estrutura, calculando os coeficientes de partição através de modelos físicos. Nestas abordagens, o coeficiente de partição é decomposto em dois termos, quais sejam: o primeiro relacionado à cavidade ou ao volume (descrevendo efeitos de volume e estéricos do soluto) e, termos que refletem interações soluto-solvente tais como: dipolo-dipolo e ligação de hidrogênio (ABRAHAM et al., 1994). Em 1974, Seiler propôs um parâmetro $\mathbf{I}_{\mathbf{H}}$, definindo as contribuições de ligações de hidrogênio, para diferentes grupos, a partir dos valores dos coeficientes de partição de determinados em diferentes sistemas de solventes, ou seja: ciclohexano/água e octanol/água. Analogamente, o parâmetro $\mathbf{V}_{\mathbf{H}}$ foi proposto para a medida da hidrofobicidade de alguns solutos. Mais ainda, introduziu-se o uso de $\Delta \log P$ para descrever as interações intermoleculares incluindo a habilidade de formar ligações de hidrogênio. (KUBINYI, 1993).

Deste modo, na investigação de sistemas químicos como modelos para descrever a interação hidrofóbica presente na partição de um composto nos sistemas biológicos, torna-se importante verificar as naturezas e as contribuições tanto dos fatores intra- $\mathrm{e}$ inter-moleculares envolvidos na partição bem como das espécies que influenciam e são responsáveis pela interação hidrofóbica, expressa pelo coeficiente de partição, $\log P_{\text {app. }}$. 
Neste contexto, em nossos laboratórios decidimos verificar os efeitos de concentração, da força iônica $(\mu)$, do $\mathrm{pH}$ e do contra-íon sobre os valores de $\log P_{\text {app }}$ de dois compostos, estruturalmente análogos da procainamida (série IIa), através do planejamento fatorial. Este trabalho fez parte dos projetos de iniciação científica de Alberto Malvezzi, Kleber Monteiro de Oliveira, Weber Cláudio Francisco Nunes da Silva, e foi realizado em colaboração com Prof. Dr. Roy Edward Bruns, UNICAMP, SP. (ANEXO, DOC. 9.3.6.2 - 81).

Deste modo, os valores do coeficiente de partição, $\log P$, foram obtidos, respectivamente por cálculo, $\log \mathrm{P}_{\text {calc }}$ (programa CLOGP, Biobyte) bem como experimentalmente, $\log P_{\text {app }}$ pelo método de shake-flask, como já descrito nesta tese, para o sistema n-octanol/água. A seguir, foram avaliadas as contribuições relativas de cada um dos fatores analisados para o valor do $\log P_{\text {app}}$, através de um planejamento fatorial $2^{4}$ (BARROS NETO, 1996). A formação de par-iônico foi analisada bem como sua contribuição para a partição. O composto estudado foi o N,N-[(dimetilamino) metil]-4-metil benzamida (série IIa), na forma de seu sal (brometo ou cloreto). Este foi escolhido entre uma série de outros análogos da procainamida por apresentar um valor de $\log P_{\text {app, }}$ próximo de 1 , valor bastante confortável para sua determinação experimental. A escolha da faixa de $\mathrm{pHs}$ foi feita considerando-se o máximo intervalo que se pode utilizar observando tanto a capacidade do tampão usado (Trizma Base) como a obediência de uma faixa linear no gráfico de de perfil $\log P_{\text {app }} v s \mathrm{pH}$. Os dois níveis de concentração foram escolhidos por constarem de trabalhos prévios no grupo e já terem demonstrado efeitos significativos sobre os valores de $\log P_{\text {app. }}$ O maior valor de força iônica já constava de trabalhos anteriores do grupo, enquanto que o menor nível é o mínimo valor de força iônica considerando-se apenas os íons presentes no tampão. $\mathrm{O}$ íon $\mathrm{Br}^{-}$foi empregado visando-se manter o mesmo valor de carga (-1) e alterar apenas seus raios iônicos, iguais a $1,81 \AA$, para cloreto e $1,96 \AA$ para o brometo. $\mathrm{O}$ planejamento do experimento e os resultados constam da Tabelas II.1.1-4 a II.1.1-5. 
Tabela II.1.1-4: Fatores e níveis utilizados no planejamento fatorial $2^{4}$<smiles>[X][NH2+]CNC(=O)c1ccc(C)cc1</smiles>

\begin{tabular}{|lcc|}
\hline \multicolumn{1}{|c}{ Fatores } & Nïvel $(-)$ & Nïvel $(+)$ \\
\hline 1. Concentração & $1,5 \times 10^{-5} \mathrm{M}$ & $1,5 \times 10^{-4} \mathrm{M}$ \\
2. pH & 7,4 & 9,0 \\
3. Força Iônica & $0,05 \mathrm{M}$ & $0,2 \mathrm{M}$ \\
4. Contra-íon & $\mathrm{Br}^{-}$ & $\mathrm{Cl}^{-}$ \\
\hline
\end{tabular}

Tabela II.1.1-5: Planejamento fatorial $2^{4}$

\begin{tabular}{|c|c|c|c|c|c|c|c|}
\hline Ensaio $^{(\text {b) }}$ & 1 & 2 & 3 & 4 & $\log P_{\text {app }} I^{(a)}$ & $\log P_{a p p} \Pi^{(a)}$ & Média \\
\hline 1 & - & - & - & - & 0,71 & $\mathrm{nd}^{(\mathrm{c})}$ & 0,71 \\
\hline 2 & + & - & - & - & 0,89 & 0,88 & 0,88 \\
\hline 3 & - & + & - & - & 0,26 & nd & 0,26 \\
\hline 4 & + & + & - & - & 1,17 & 0,76 & 0,965 \\
\hline 5 & - & - & + & - & 0,67 & 0,95 & 0,81 \\
\hline 6 & + & - & + & - & 0,85 & 0,71 & 0,78 \\
\hline 7 & - & + & + & - & 1,02 & $n \mathrm{~d}^{(\mathrm{c})}$ & 1,02 \\
\hline 8 & + & + & + & - & 1,13 & $n d^{(c)}$ & 1,13 \\
\hline 9 & - & - & - & + & 0,32 & $\mathrm{nd}^{(\mathrm{c})}$ & 0,32 \\
\hline 10 & + & - & - & + & 0,88 & 0,75 & 0,815 \\
\hline 11 & - & + & - & + & 0,67 & 0,42 & 0,54 \\
\hline 12 & + & + & - & + & 0,79 & 0,79 & 0,79 \\
\hline 13 & - & - & + & + & 0,46 & 0,55 & 0,505 \\
\hline 14 & + & - & + & + & 0,88 & 0,85 & 0,865 \\
\hline 15 & - & + & + & + & 0,85 & 0,83 & 0,84 \\
\hline 16 & + & + & + & + & 1,26 & 1,10 & 1,18 \\
\hline
\end{tabular}

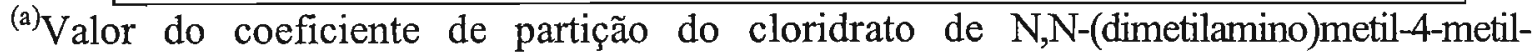
benzamida obtido a partir do método de shake flask; e todos os experimentos foram executados em duplicata para a determinação do erro experimental.

(b) Número do ensaio não corresponde a ordem cronológica em que foram realizados os experimentos. Estes foram feitos em ordem aleatória para evitar distorções estatísticas;

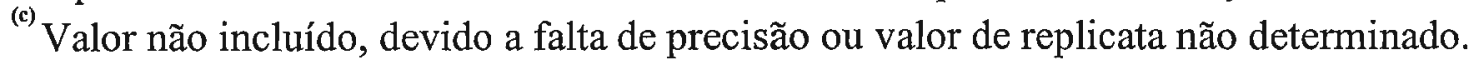

Os efeitos foram calculados introduzindo os valores das médias das duas duplicatas no programa FATORIAL (BARROS NETO, 1996). 
Tabela II.1.1-6: Efeitos significativos e seus intervalos de confiança de $95 \%$

\begin{tabular}{|cc|cc|}
\hline \multicolumn{2}{|c|}{} \\
\hline \multicolumn{2}{|c|}{ Efeitos principais } & \multicolumn{2}{c|}{ Efeitos de interação } \\
\hline Ef. $($ Conc.) & $0.3 \pm 0.10$ & Ef.(Conc. $\mathrm{x} \mu)$ & $-0.11 \pm 0.10$ \\
Ef. $(\mathrm{pH})$ & $0.13 \pm 0.10$ & Ef. $(\mathrm{pH} x \mu)$ & $0.1725 \pm 0.10$ \\
Ef. $(\mu)$ & $0.23 \pm 0.10$ & Ef. (Conc. $\mathrm{x} \mathrm{pH} \mathrm{x} \mathrm{Contra} \mathrm{íon)}$ & $-0.1175 \pm 0.10$ \\
\hline
\end{tabular}

A análise dos efeitos principais e das interações significativas indica que:

Concentração: É o fator que apresenta o maior efeito na determinação do $\log P$ (Tabela II.1.1-6). O aumento da concentração do soluto gera um aumento das interações intermoleculares. Ao aumentarmos a concentração do composto estamos aumentando a probabilidade de formação do par iônico e assim nota-se um aumento do valor do $\log P_{\text {app }}$ da molécula, pois o par iônico, apresentando menor caráter iônico se particiona mais para a fase orgânica, relativamente as espécies iônicas solvatadas.

pH: É o terceiro fator importante (Tabela II.1.1-6). O compostos anlisado são bases fracas sujeitas a protonação $\left(\mathrm{pK}_{\mathrm{a}}=7,56\right)$. Variação no $\mathrm{pH}$ promove uma mudança na posição do equilíbrio entre as espécies protonadas e não protonadas. Em pH 9,0, aproximadamente $96 \%$ das moléculas do composto estão desprotonadas, o que contribui significativamente para o aumento da lipossolubilidade e respectivamente do $\log P_{\text {app }}$. No $\mathrm{pH} 7,4$ valor próximo ao $\mathrm{pK}_{\mathrm{a}}$ estabelece-se um equilíbrio de mais ou menos $50 \%$ de cada espécie. Nesse caso a presença de espécies ionizadas vai aumentar a solubilidade relativa na fase aquosa, resultando em uma redução do $\log P_{\text {app }}$. Portanto o que se observa é uma redução do $\log P_{\text {app }}$ para valores menores de $\mathrm{pH}$.

Força iônica: é o segundo fator mais importante (Tabela II.1.1-6) . O aumento da força iônica significa o aumento da concentração de ions em solução que juntos com a benzamida protonada vão formar o par iônico causando uma aumento do $\log P_{\text {app }}$, discutido no ítem anterior. Outro aspecto a considerar é a diminuição da solubilidade do composto na solução tampão com o aumento da força iônica. Aqui o aumento da quantidade de íons dissolvidos no tampão vai diminuir a solubilidade do composto “expulsando-a" da fase aquosa, aumentando a sua hidrofobicidade $\left(\log P_{\text {app }}\right)$. Não menos 
importante é o efeito da força iônica sobre o valor do $\mathrm{pK}_{\mathrm{a}}$ do composto. Segundo É conhecido que o valor do $\mathrm{pK}_{\mathrm{a}}$ de bases fracas aumenta com o aumento da força iônica. Sendo assim quando o valor da força iônica for maior, o valor do $\mathrm{pK}_{\mathrm{a}}$ aumenta e a concentração do composto não-protonado é maior do que em força iônica menor. Portanto a concentração do composto em octanol; é maior, ou seja, a solubilidade relativa no octanol vai aumentar, elevando o valor do $\log P_{\text {app. }}$.

Considerando-se cada um dos efeitos isoladamente, pode-se dizer, que o planejamento fatorial, de forma geral, indicou: o $\mathrm{pH}$ vai reger o grau de ionização de grupamentos ionizáveis; a força iônica vai alterar tanto o $\mathrm{pK}_{\mathrm{a}}$ e a solubilidade da molécula bem como a formação do par iônico (SCHERRER, 1996); a natureza do tampão vai determinar $\mathrm{a}(\mathrm{s})$ natureza(s) de interação soluto-tampão; e finalmente a concentração do soluto, a intensidade das relações intermoleculares. No entanto, nos sistemas biológicos (real) estes fatores variam e a seleção dos níveis (valores absolutos da variáveis/fatores analisadas,) para serem usados no modelo experimental se torna um procedimento arbitrário e unilateral.

Outro aspecto a ser considerado é a interação entre as variáveis. Considerando-se todo os equilíbrios envolvidos, muito frequentemente os fatores podem se influenciar mutuamente, e o valor a ser selecionado para um deles pode depender do valor atribuído ao outro. Com o auxílio de ferramentas estatísticas, mais especificamente a planejamento fatorial, podemos planejar uma série de simples experimentos que avaliem quantitativamente a influência de cada variável sobre a resposta, assim como os efeitos de interação entre as variáveis. O planejamento fatorial consiste na execução de experimentos para todas as possíveis combinações dos níveis dos fatores. O cálculo dos efeitos e a análise dos resultados vão indicar se os fatores tem ou não influência sobre a resposta, e até que ponto uma variação no nível do fator vai gerar uma mudança significativa na resposta. Com os resultados da análise fatorial podemos propor modelos experimentais mais fiéis as interações que ocorrem no sistemas biológicos, ou pelo menos estabelecer mais claramente a correlação entre ambos.

Os resultados apresentados na Tabela II.1.1-6, indicam que :

Conc. $x$ força iônica. Fatores de interação: $O$ efeito de interação entre a concentração e a força iônica sobre $\log P_{\text {app }}$ demonstrou ser um processo não cumulativo. Isoladamente os dois fatores contribuem para o aumento do logPapp, mas 
quando combinados a contribuição de cada um deles é menor. Sugere-se que esse fenômeno ocorre provavelmente pois quando os dois fatores estão em seus níveis mais baixos as sensibilidades aos efeitos diminuem devido a menor concentração da espécie presente

$\mathrm{pH} \times$ força iônica. Fatores de interação bastante significativos. Assim, o aumento do $\mathrm{pH}$ da solução com força iônica alta resulta em um aumento maior no $\log P_{\text {app }}$ em comparação com o mesmo aumento de $\mathrm{pH}$ na solução com força iônica baixa. Observando mais atentamente os resultados apresentados na Tabela II.1.1-5, é possível constatar ainda que a variação mais forte ocorre quando se tem a força iônica alta (fator 3) e o $\mathrm{pH}$ mais elevado (fator 2). No $\mathrm{pH} 9.0$, onde praticamente todo composto está desprotonado, a força iônica alta contribui para a redução da solubilidade da benzamida no tampão ao mesmo tempo que aumenta seu $\mathrm{pK}_{\mathrm{a}}$. Os dois efeitos são aditivos e cumulativos e observa-se que o efeito de interação potencializa estes fatores, resultando num aumento do valor de log Papp maior do que o esperado considerando os fatores isoladamente.

Contra-íon. Fator não significativo na determinação do $\log P_{\text {app }}$ (tabela II.1.1-6) Isso se deve principalmente a pequena diferença entre os dois contra-íons usados. Cloreto e brometo são monovalentes com raios iônicos próximos (Tabela II.1.1-4), o que resultou numa variação no $\log P_{\text {app }}$ não significativa, ou seja menor que o erro experimental. O contra-íon é sem dúvida é um fator importante na formação do par iônico. Quanto mais lipofílico o contra-íon, mais estável será o par iônico.

Pelos resultados da Tabela II.1.1-6, observamos que os valores do $\log P_{\text {app }}$ são maiores quando ocorrem aumentos na concentração, na força iônica e no pH. Para os níveis usados neste trabalho, a concentração é o fator mais importante seguido da força iônica. O efeito de interação mais importante é observado entre $\mathrm{pH}$ e força iônica. $\mathrm{O}$ aumento de $\mathrm{pH}$ da solução com valor de força iônica alto resulta em um aumento significativo no $\log P_{\text {app }}$, enquanto que, para soluções com força iônica baixo o $\log P_{\text {app }}$ mantém-se constante, dentro do erro experimental. Pela análise, a natureza dos contraíons, $\mathrm{Cl}^{-}$ou $\mathrm{Br}^{-}$, não é importante na determinação do valor de $\log P_{\text {app }}$. Portanto, valores altos de $\log P_{\text {app }}$ são favorecidos por níveis altos de concentração, de $\mathrm{pH}$ e de força iônica. 
Prosseguindo com a investigação das contribuições expressas nos valores de $\log P_{a p p}$ em séries de benzamidas (série IIa) e a partir dos resultados obtidos no planejamento fatorial, neste trabalho realizado em nossos laboratórios, (ANEXO V). consideramos três compostos da série, a saber: compostos $\left(\mathrm{R}=\mathrm{CH}_{3}\right) ;\left(\mathrm{R}=\mathrm{n}-\mathrm{C}_{4} \mathrm{H}_{9}\right)$ e $\left(\mathrm{R}=\mathrm{SO}_{2} \mathrm{CH}_{3}\right)$. Os valores de $\log P_{\text {app }}$ no sistema ocatanol/água foram determinados na faixa de pH entre 3,0-11,0. Foi feita a adição externa de três espécies como contra-íons, respectivamente, propionato de sódio (prop); valerato de sódio e caproato de sódio (cap) e t-butilacetato de sódio (t-BuAc) em duas proporções. (1:1 e 1:100). Este foi tema dos projetos de iniciação científica de Alberto Malvezzi, Celina Yumi Motizuki, Danilo Sergio Policastro, Weber Nunes da Silva. (ANEXO V).

Deste estudo, pode-se concluir que o efeito do contra-ion sobre o coefciente de partição, varia significativamente em cada $\mathrm{pH}$ examinado. $\mathrm{Em} \mathrm{pH}$ 9.0, não se observou efeito significativo, sugerindo a presença somente da base livre esta contribuindo para a partição. Em pH 4,0, por outro lado, um efeito significativo é observado, que pode estar associado a formação de par-iônico, considerando que os outros efeitos estariam também contribuindo em pH 9,0. Para o composto (4- $\left.\mathrm{SO}_{2} \mathrm{CH}_{3}\right)$ a partição da forma ionizada, expressa por $\log P_{\mathrm{i}}$ é desprezível, para todos os contra-íons estudados, sugerindo que somente a base livre deve contribuir para a partição. A ausência de pariônico para compostos tendo valores de $\mathrm{pH}$ baixos, pode indicar que não há formação de par-iônico. Para os compostos (4-Me) e $\left(4-\mathrm{C}_{4} \mathrm{H}_{9}\right)$ no $\mathrm{pH} 4,0$ o valor observado de $\log P_{\text {app }}$ pode estar associado com a formação do par iônico.

Em nosso grupo, outros aspectos relacionados ao parâmetro hidrofóbico constam de estudos preliminares ou estão em andamento, desta forma não foram aqui relatados. Como perspectivas pretendemos incluir em nossos projetos estudos das interações hidrofóbicas, considerando o seu potencial lipofílico molecular, calculado. Para a seguir, poder comparar com os valores experimentais revelando informações importantes sobre interações inter- e intramoleculares presentes na lipofilicidade, foco de nosso maior interesse.

\section{II.1.2. Parâmetros Eletrônicos, Estéricos e relacionados à polarizabilidade}

Os parâmetros eletrônicos ou polares descrevem, em geral, o(s) efeito(s) de um determinado(s) grupo(s) substituinte(s) sobre a distribuição eletrônica da 
molécula. As propriedades relacionadas aos efeitos eletrônicos e polares podem ser descritas por uma grande variedade de parâmetros (KUBINYI, 1993, HANSCH, LEO, HOEKMAN, 1995). Estes podem ser calculados por métodos de mecânica quântica ou de mecânica molecular, sendo expressos por exemplo, por: valores de cargas atômicas parciais e HOMO, LUMO e, podem ainda ser retirados da literatura (KUBINYI, 1993, HANSCH, LEO, HOEKMAN, 1995); como por exemplo as constantes eletrônica de grupos substituintes $\sigma$ de Hammet, $\mathfrak{I}$ e $\mathfrak{R}$ de Swain e Lupton (SWAIN, LUPTON, 1968). Estes últimos foram escalonados de forma mais consistente (CHARTON, 1981, HANSCH, LEO, HOEKMAN, 1995). Compilação mais recente (HANSCH, LEO, TAFT, 1991) contém os valores de $\sigma$ de Hammet, de $\mathfrak{T}$ e $\mathfrak{R}$ de Swain e Lupton, para mais de 500 substituintes.

Parâmetros polares ou eletrônicos podem ser determinados experimentalmente como por exemplo através de técnicas espectroscópicas, ou seja, a partir dos espectros de $\mathbf{R M N}-{ }^{1} \mathbf{H}$ e de $\mathbf{R M N}-{ }^{13} \mathbf{C}$ bem como na região do espectro na região do infra-vermelho, (AMARAL, AMARAL, 1976; BARONI; R, 1987; TAVARES, L, 1987; AMARAL, MIYAZAKI, STACHISSINI et al., 1991; AMARAL, MIYAZAKI, CAPOBIANCO et al., 1993; AMARAL, MIYAZAKI, TAVARES et al., 1995; MIGUEL, S, 1992; AMARAL, OLIVEIRA, NEIDLEIN et al., 1997; TAVARES, PENNA, AMARAL, 1997; RAMINELLI, 2001; SILVEIRA, 2001) e ainda através de várias outras técnicas metodológicas, como potencial de redução (EDWARDS, 1990; PIRES et al, 2000 e, PIRES et al, 2001).

Os parâmetros estruturais determinados por métodos experimentais tornam-se particularemente importantes (sendo mesmo recomendados) para sistemas nos quais os valores das diversas coletâneas de constantes eletrônicas de substituintes ou não são tabelados (como por exemplo, valores de constante eletrônica tipo $\sigma$ de Hammett para sistemas contendo anéis heterocíclicos) ou não são adequados para descrever as interações que estão ocorrendo no sistema estudado, em especial as de naturezas intra-moleculares. Cada parâmetro experimental, no entanto, deve ser, previamente, validado, para ser utilizado em análises de QSAR (AMARAL, et al, 1997; RAMINELLI, 2001; SILVEIRA, 2001; PIRES et al, 2001).. 
Assim, em nosso laboratórios a utilização dos valores de deslocamentos químicos de $\mathrm{RMN}-{ }^{13} \mathrm{C}$ observados para o carbono carbonílico, ou da posição da banda de aborção na região do infra-vermelho ou de valores do potencial de redução obtidos por voltametria cíclica, como parâmetros eletrônicos experimentais, foram analisadas e validadas pela aplicação da equação tipo-Hammett aos correspondentes valores observados para cada série de compostos estudados. (ANEXO IV) (ANEXO VI) (ANEXO M-6) (ANEXO M-7).

Dados de literatura apontavam que a densidade eletrônica no grupo carbonila como importante para a atividade anestésica local (STRICHARTZ, 1987). Assim, consideraram que a distribuição eletrônica do grupo carbonila, presente na maioria dos anestésicos locais, tem papel importante para estabelecimento desta atividade STRICHARTZ, 1987. Sendo assim, propõe-se que a atividade anestésica local seja afetada por grupos substituintes presentes no anel aromático, através de seus efeitos tanto hidrofóbicos como também de natureza polar (efeitos indutivo e de ressonância). Sabendo-se que estes últimos afetam diretamente a distribuição eletrônica no oxigênio carbonílico, propõe-se, como conseqüência, que a polaridade do grupo carbonila possa estar, em princípio, modulando a atividade do anestésico local.

Baseados nestes trabalhos e, procurando aplicar e ampliar os conhecimentos anteriormente adquiridos, iniciamos nossos trabalhos em $Q S A R$, através do estudo dos efeitos de substituintes sobre a frequência de estiramento do grupo carbonila de derivados de ácidos benzóicos, em especial compostos com potencial atividade anestésica local. Como relatados em detalhes no memorial, este trabalho foi iniciado com a colaboração da Profa. Marilene P.B.Ceneviva, Faculdade de Ciências Farmacêuticas, Universidade de São Paulo. Com sua morte prematura, participei da coorientação e do término da dissertação de mestrado de dois de seus orientados Rosely V. Baroni e Leoberto da Costa Tavares.

Nestes duas dissertações de mestrado utilizamos parâmetros espectroscópicos, determinados experimentalmente para descrever a distribuição da densidade eletrônica/variação da polaridade no grupo carbonila, através de $\left(v_{\mathrm{C}=0}\right.$ ou $\left.\delta{ }^{13} \mathrm{C}=0\right)$, para série de derivados da procaína, um anestésico local conhecido bem como para série de tiosemicarbazonas com atividade antimicrobiana. Ao mesmo tempo elucidamos a(s) 
natureza(s) e grandeza(s) da(s) dos efeitos eletrônicos transmitidos pelos grupos substituintes, sobre $\boldsymbol{v}_{\mathrm{C}=\mathrm{o}}$ ou $\delta \mathbf{1 3}_{\mathbf{C}=\mathbf{o}}$ e as correspondentes atividades biológicas.

A seguir, realizamos estágios com os profs. Richard Neidlein e Hugo Kubiny, na Universidade de Heidelberg. Lá aplicamos nossos conhecimentos prévios, para validar o uso de parâmetros espectroscópicos como parâmetros eletrônicos, para descrever a atividade anestésica local de série de compostos análogos à procaina. E, de modo análogo, elucidamos a(s) natureza(s) e grandeza(s) da(s) dos efeitos eletrônicos transmitidos pelos grupos substituintes, sobre $v_{\mathrm{C}=\mathbf{0}}$ ou $\delta^{\mathbf{1 3}} \mathrm{C}=\mathbf{0}$ e a correspondente atividade biológica.

Com este objetivo, em nosso laboratório temos estudado diversos parâmetros eletrônicos experimentais, quais sejam obtidos tanto por métodos espectrométricos tipicamente $v_{\mathrm{C}=\mathrm{O}}$ e $\delta{ }^{13} \mathrm{C}=\mathrm{O}$ bem como por voltametria cíclica, tipicamente $E$ (potencial de redução) de séries de compostos, compilados no texto desta tese de modo análogo ao considerado já considerado na descrição do parâmetro hidrofóbico.

Dentro desta abordagem nosso laboratório realizou o estudo dos efeitos dos substituintes sobre a polaridade do grupo carbonila de nove $\mathrm{N}$-[(dimetilamino) metil] benzamidas 4-X-substituídas em que $\mathrm{X}=\mathrm{NO}_{2}, \mathrm{Br}, \mathrm{Cl}, \mathrm{F}, \mathrm{I}, \mathrm{H}, \mathrm{CH}_{3}, \mathrm{OCH}_{3}$ e $\mathrm{N}\left(\mathrm{CH}_{3}\right)_{2}$ fornecidos gentilmente por Prof. Roberto Rittner, UNICAMP, SP - e de seus respectivos cloretos (neste texto classificados como série Ia na formas de cloretos e das correspondentes bases livres) analisados através da observação do deslocamento da posição da banda de absorção do grupo carbonila na região do I.V. Este estudo foi feito de modo sistemático e, em solução de clorofórmio. Assim, foi possível atribuir os deslocamentos observados como sendo devidos somente aos efeitos polares introduzidos e transmitidos pelos substituintes. Este foi tema da dissertação de mestrado de Leoberto da Costa Tavares e os resultados foram publicados cpublicou (ANEXO IX) e (ANEXO M-2).

Na tabela II.1.1-2 (ANEXO IX) encontram-se reunidos os valores das médias das freqüências $\left(\mathrm{cm}^{-1}\right)$ de absorção do grupo carbonila, $v \dot{C}=\mathrm{O}$, determinados na região do I.V., para as séries de $\mathrm{N}$-[(dimetilamino) metil] benzamidas 4-substituídas e dos correspondentes cloridratos. Verificamos, como esperado, que grupos substituintes aceptores de elétrons deslocam a posição da banda de absorção do grupo $>\mathrm{C}=\mathrm{O}$ para valores de maior freqüência $\left(\mathrm{cm}^{-1}\right)$ em relação ao composto não-substituído e que 
deslocamento oposto é observado para substituintes doadores de elétrons. Observou-se ainda que, para o mesmo grupo substituinte, os valores de $v_{\mathrm{M}} \mathrm{C}=\mathrm{O}$ da série de cloretos são maiores do que os correspondentes valores observados para as bases livres. Esta observação pode ser explicada considerando-se a transmissão do efeito indutivo (-I ), pelo grupo dimetilamônio, aceptor de elétrons, desestabilizando a estrutura II em relação à estrutura I, como representado na figura II.1.2.1, (ANEXO IX).

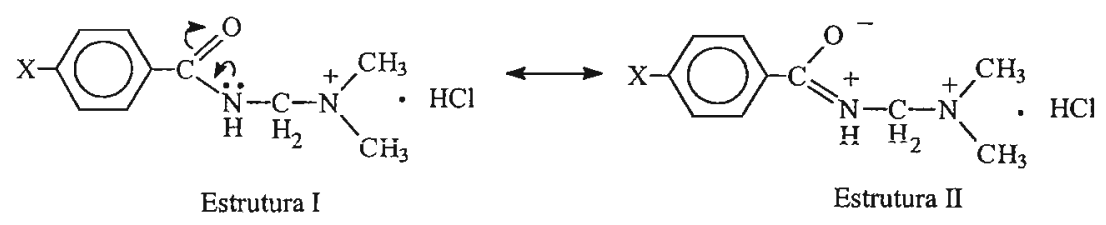

Figura II.1.2 -1 Representação esquemática do efeito da protonação do nitrogênio amínico sobre a polaridade do grupo carbonila na série de $\mathrm{N}$-[(dimetilamino) metil] benzamidas 4-X-substituídas, em que $\mathrm{X}=\mathrm{NO}_{2}, \mathrm{Br}, \mathrm{Cl}, \mathrm{F}, \mathrm{I}, \mathrm{H}$, $\mathrm{CH}_{3}, \mathrm{OCH}_{3}$ e $\mathrm{N}\left(\mathrm{CH}_{3}\right)_{2}$

Comportamento semelhante foi observado e discutido anteriormente no ítem parâmetros hidrofóbicos. Assim sugerimos que para esta série de compostos, série IIa $(\mathrm{n}=9)$ a presença de um efeito de proximidade de grupos polares explica a maior lipofilicidade observada quando comparada com as dos correspondentes benzoatos ou com a da procainamida que contem dois grupos metilênicos na cadeia intermediária. Sendo possível, incluisive para as séries reunidas $(n=26$, séries Ia e Ib) propormos um modelo, incluindo-se uma variável indicadora. $\mathbf{I}\left(\mathbf{o C O C H}_{2}\right)$.

Ainda salientamos (ANEXO IX) a importância da avaliação experimental da propriedade, em especila da polaridade do grupo carbonila visando o mapeamento da distribuição eletrônica nos compostos estudados pode ser compreendida considerandose, inicialmente, as limitações inerentes aos parâmetros eletrônicos encontrados na literatura, definidos a partir de reações químicas simples, ou seja, para sistemas mais simples do que o sistema biológico. Desta forma, as interações polares que ocorrem na interação composto-sistema biológico podem ser mais complexas do que aquelas presentes nos sistemas utilizados para definir os referidos parâmetros como, por exemplo, o parâmetro $\sigma$ de Hammett definido a partir da ionização de ácidos benzóicos substituídos. 
Assịm, em estudos de $Q S A R$ nas quais uma propriedade relacionada à distribuição eletrônica contribui para a resposta biológica, recomenda-se, na medida do possível, o emprego de parâmetros definidos experimentalmente através de sistemáticas adequadas para a finalidade. Alternativamente recomenda-se a utilização das constantes de substituintes $\mathfrak{I}$ e $\mathfrak{R}$ de Swain e Lupton que se relacionam com os efeitos de campo, indutivo e de ressonância e que, por definição, independem da posição que o substituinte ocupa no anel aromático. A validade de se utilizar em especial os valores, de $v_{\mathrm{C}=\mathrm{O}}$ como parâmetro descritor da distribuição eletrônica no grupo carbonila refletindo, portanto, as interações inter- e intra-moleculares presentes, foi verificada através da aplicação da equação de Hammett simples e expandida, aos valores de freqüência, $v_{\mathrm{C}=\mathrm{O}}$, em função de diferentes coleções de parâmetros físico-químicos disponíveis na literatura relacionados com a propriedade eletrônica do grupo substituinte.

A utilização dos valores da posição de absorção do grupo carbonila - obtidos de modo sistemático na região do espectro no infravermelho - como parâmetro eletrônico descritor do(s) efeito(s) transmitido(s) pelos grupos substituintes para séries de análogos da procaína e da procainamida foi tema das dissertações de Mestrado de Leoberto da Costa Tavares (ANEXO M-2), de Sylvia Regina de Mattos Miguel (ANEXO M-3) de Yoshinori Miyazaki (não completada); de Leonardo Siqueira (ANEXO M-7) e, para série de derivados de bases de Mannich, com atividade citotóxica, estudada por Cristiano Raminelli (ANEXO M-6). Este parâmetro eletrônico experimental foi tema ainda de vários projetos de iniciação científica.

Em várias publicações recentes, estes parâmetros experimentais foram utilizados como descritores em análises de QSAR (AMARAL, MIYAZAKI, STACHISSINI et al., 1991; AMARAL, MIYAZAKI, CAPOBIANCO et al., 1993; AMARAL, MIYAZAKI, TAVARES et al., 1995; AMARAL, OLIVEIRA, NEIDLEIN et al., 1997; TAVARES, PENNA, AMARAL, 1997; RAMINELLI, 2001; SILVEIRA, 2001). Estas serão discutidas no CAPÍTULO III.1.

Em nosso laboratório, ampliamos o estudo de parâmetros eletrônicos experimentais, com a inclusão dos valores de deslocamentos químicos de $\mathbf{R M N}-{ }^{13} \mathbf{C}$ observados para o carbono carbonílico. Estes foram analisados - de modo análogo e considerando as limitações de cada método - pela aplicação da equação tipo-Hammett 
aos valores observados inicialmente para séries de derivados da tiossemicarbazona, com atividade antimicrobiana. Este foi tema da dissertações de mestrado de Rosely V. Baroni (ANEXO M-1). E, mais recentemente, nosso laboratório empregou este parâmetro eletrônico experimental, $\delta_{\mathrm{C}=0}$, tanto para séries de análogos da procaína e da procainamida sendo tema da dissertação de mestrado de Leonardo Siqueira (ANEXO M-7) bem como para série de derivados de bases de Mannich, com atividade citotóxica, sendo este o tema da dissertação de Mestrado de Cristiano Raminelli (ANEXO M-6).

Uma das colaborações nesta área foi a determinação dos valores do deslocamento químico de $\mathrm{RMN}$ de ${ }^{13} \mathrm{C}$ do grupo carbonila $\left(\delta^{13}{ }_{\mathrm{C}=\mathrm{O}}\right)$, em uma única concentração $(\sim 0,1$ $\mathrm{mol} / \mathrm{L})$ para série de brometos de [2-(4-X-benzamido)etil]benzildimetilamônio substituídos (compostos IIIa.1 a IIIa.11).

Os valores observados para $\delta^{13} \mathrm{C}=\mathrm{O}$ (obtidos em um espectrômetro Varian INOVA 300 a $75 \mathrm{MHz}$, utilizando-se metanol- $d_{4}$ como solvente, tomando-se como referência o sinal em 49,00 ppm de metanol-d $\mathrm{d}_{4}$ e concentrações de $\sim 0,1 \mathrm{~mol} / \mathrm{L}$. Precisão de $\pm 0,01$ ppm de acordo com especificações do aparelho) estão em concordância com o esperado para benzamidas substituídas. Os valores de $\delta^{13} \mathrm{C}=\mathrm{O}$ sofrem influência dos substituintes em para no anel aromático, embora esta seja pequena $(<3 \mathrm{ppm})$. Para substituintes retiradores de elétrons os valores de $\delta^{13}{ }_{\mathrm{C}=\mathrm{O}}$ se apresentam em campo mais alto em relação a substituintes doadores de elétrons. Na literatura (CRAIK, 1983) ${ }^{]}$, estudos da influência de substituintes em para no anel aromático sobre os valores de deslocamento químico do grupo carbonila de amidas aromáticas mostram variações comparáveis, próxima de $3 \mathrm{ppm}$. Grupos substituintes aceptores de elétrons deslocam os valores de $\delta^{13}{ }_{C}=0$ para valores de campo baixo, enquanto, grupos doadores de elétrons deslocam os valores de $\delta^{13}{ }_{\mathrm{C}=\mathrm{O}}$ para valores de campo alto.

A aplicação da equação tipo Hammett aos valores de $\delta^{13}{ }_{\mathrm{C}=0}$ em função dos valores das constantes eletrônicas de substituintes de Hammett $\sigma_{\mathrm{p}}$, resultou nas equações II.1.2 -1 (compostos IIIa.1 a IIIa.11), (compostos IIIa.1- IIIa.4 e IIIa.6-IIIa.11) e em função de $\mathfrak{J}, \mathfrak{R}$ de Swain-Lupton resultou na equação II.1.2-2.(compostos IIIa.1-IIIa.11), sendo estas significativas. 


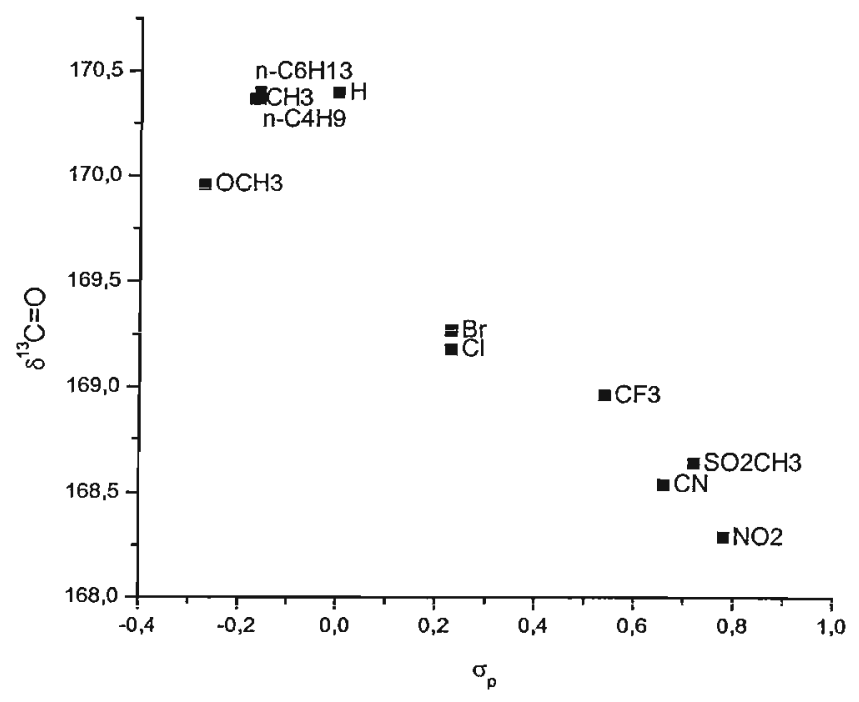

$\delta^{13}{ }_{C=0}=-1,98( \pm 0,50) \sigma_{p}+169,90( \pm 0,22) \quad$ equação II.1.2 -1
$n=11 ; \quad r=0,95 ; s=0,28 ; F=80,32 ; Q^{2}=0,85 ; s_{P R E S S}=0,34$

Figura II.1.2 -2. Correlação obtida entre os valores das constantes de substituinte Hammett $\left(\sigma_{\mathrm{p}}\right)$ e do deslocamento químico de $\mathrm{RMN}$ de ${ }^{13} \mathrm{C}$ do grupo carbonila $\left(\delta^{13} \mathrm{C}=\mathrm{O}\right)$ para a série de brometos de [2-(4-X-benzamido)etil]benzildimetilamônio substituídos, compostos IIIa.1-MIa.11.

Pode-se observar, no entanto, que o valor de $\delta^{13}{ }_{\mathrm{C}=\mathrm{O}}$ do composto IIIa.5 $\left(\mathrm{X}=\mathrm{OCH}_{3}\right)$ apresenta um comportamento anômalo ao apresentados pelos outros substituintes, não sendo descrito pelo modelo expresso pela equação II.1.2-1 . A exclusão do composto I.5 resulta na equação II.1.2 -2.

\section{Sem composto $\mathbf{I . 5}$}

$$
\begin{aligned}
& \delta^{13}{ }_{C=O}=-2,18( \pm 0,43) \sigma_{p}+170,00( \pm 0,20) \quad \text { equação. II.1.2-2 } \\
& n=10 ; r=0,972 ; s=0,21 ; F=134,59 ; Q^{2}=0,92 ; s_{P R E S S}=0,25
\end{aligned}
$$

Como pode ser observado, a equação II.1.2-2 explica cerca de $97 \%$ dos resultados. Assim, do ponto de vista estrutural, os resultados sugerem que a influência dos grupos substituintes sobre a blindagem do carbono carbonílico parece ser devido a efeitos indutivos transmitidos pelos grupos substituintes. Para avaliar a(s) natureza(s) da influência do efeito eletrônico, ou seja, verificar se a blindagem do carbono carbonílico ocorre preponderantemente através de efeitos de campo/indutivo ou de ressonância foi 
aplicada a equação de Hammett expandida utilizando-se os parâmetros $\mathfrak{I} e \mathfrak{R}$ de $S$ wain e Lupton .

$$
\begin{aligned}
& \delta^{I 3}{ }_{C=O}=-2,82( \pm 0,30) \mathfrak{I}-0,94( \pm 0,51) \Re+170,20( \pm 0,17) \quad \text { eq. II.1.2 -3 } \\
& n=11 ; \quad r=0,994 ; s=0,098 ; F=359,47 ; Q^{2}=0,98 ; s_{P R E S S}=0,13
\end{aligned}
$$

A análise da equação tipo Hammett expandida equação I.1.2-3, sendo estatisticamente significativa, mostra que a influência dos grupos substituintes sobre a blindagem do carbono carbonílico de amidas aromáticas. é (67\%)de naturezas de campo-indutivo e (33\%)de ressonância.

Estudos análogos encontrados na literatura (CRAIK, 1983) realizados em clorofórmio deuterado como solvente, para uma série de 14 benzamidas para substituídas e utilizando $\sigma_{\mathrm{I}}$ como constante eletrônica de substituinte, medindo $\delta^{13} \mathrm{C}=0$, mostraram que a contribuição do efeito transmitido pelo substituinte é de natureza campo/indutivo $\left(\rho_{\mathrm{I}}\right)$, sendo esta de $-2,7 \pm 0,3$. Desta forma, a influência de substituintes que doam elétrons por campo/indução favorece a polarização $\left(\mathrm{C}^{+}-\mathrm{O}^{-}\right)$do grupo carbonila, apresentando sinal em campo mais baixo em relação ao sinal observado para o composto não substituído. Por outro lado, para grupos aceptores observa-se um deslocamento oposto.. Concordantemente, dados de cristalografia de Raio X (PENFOLD, 1959) mostram que o ângulo encontrado entre os planos da ligação carbonila de amidas e do anel aromático é de $26^{\circ}$, desfavorecendo a conjugação estendida entre o substituinte e o grupo carbonila. Assim, estes resultados de literatura corroboram as informações obtidas pela equação de Hammett expandida, aplicadas aos compostos IIIa.1-III.a11. Ou seja, a natureza do efeito eletrônico transmitido pelos grupos substituintes é de natureza preponderantemente campo/indutiva.

Para a série IIIa, os valores de deslocamento químico de $\mathrm{RMN}$ de ${ }^{13} \mathrm{C}$ do grupo carbonila $\left(\delta^{13}{ }_{\mathrm{C}=\mathrm{O}}\right)$ foram utilizados como parâmetro eletrônico experimental, com o objetivo de se estudar o efeito da distribuição eletrônica do grupo carbonílico sobre o bloqueio da transmissão neuromuscular, dicutida no CAPÍTULO III.1.

Adicionalmente, em nosso laboratório, para série de derivados 5-nitrofurânicos, com atividade antibacteriana - compilados neste tese como séries IV - foram avaliados como parâmetros eletrônicos os valores dos potenciais de redução determinados por 
voltametria cíclica; as energias dos orbitais LUMO (E-LUMO, em eV) calculadas pelo método semi-empírico AM1, através do pacote de programas MOPAC 6.0. e, as séries de constantes de eletrônicas dos substituintes $\sigma_{\mathrm{m}}, \sigma_{\mathrm{p}}$ de Hammett, $\mathfrak{J}$ e $\mathfrak{R}$ de Swain e Lupton retiradas da literatura. Estes estão apresentados na tabela II.1.2-1 foram utilizados como parâmetros eletrônicos em análise de $Q S A R$ para as três de derivados 5nitrofurânicos, com atividade antibacteriana - compilados neste tese como séries IV.I, IV.II e IV.III, apresentadas e discutidas no CAPÍTULO III.2 . (ANEXO VI) e (ANEXO DII).

Nesta série de compostos, além das constantes eletrônicas dos substituintes, que são tradicionalmente utilizadas em estudos de $Q S A R$, a utilização dos valores dos potenciais de redução medidos experimentalmente e os valores de energia dos orbitais LUMO calculados, em nossos estudos, se justificam pela indicação da literatura, que sugere que o potencial de redução é uma propriedade importante na explicação da atividade de compostos nitrofurânicos e outros compostos nitroheterocíclicos. Adicionalmente, deve-se considerar também que os valores de $\sigma_{\mathrm{m}}, \sigma_{\mathrm{p}}$ de Hammett, definidos a partir das constante de ionização de ácidos benzóicos frequentemente não se aplicam a sistemas heterocíclicos. 
Tabela II.1.2-1.Valores das constantes eletrônicas de substituinte $\sigma_{m}, \sigma_{p}$ de Hammett e $\mathfrak{I}$ e $\mathfrak{R}$ de Swain e Lupton, retirados da literatura; da energia dos orbitais LUMO, calculados pelo método semiempírico AM1 e do potencial de redução, obtidos por voltametria cíclica, para os compostos das séries IV.I, IV.II e IV.III.

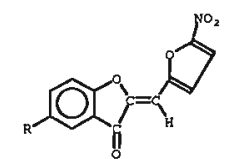

Série I

\begin{tabular}{|c|c|c|c|c|c|c|c|}
\hline Composto & $\begin{array}{c}\text { Substituinte } \\
\text { (R) }\end{array}$ & $E(V)^{a}$ & $\begin{array}{c}\text { E-LUMO } \\
(\mathrm{eV})\end{array}$ & $\sigma p^{c}$ & $\sigma_{\mathrm{m}} \mathrm{c}$ & $\mathfrak{I}^{\mathrm{c}}$ & $\mathscr{R}^{\mathrm{c}}$ \\
\hline I.1 & $5-\mathrm{OCH}_{3}$ & -0.27 & -1.95 & -0.27 & 0.12 & 0.29 & -0.56 \\
\hline 1.2 & $\mathrm{H}$ & -0.24 & -1.90 & 0 & 0 & 0 & 0 \\
\hline $\mathbf{I . 3}$ & $5-\mathrm{CH}_{3}$ & -0.33 & -1.87 & -0.17 & -0.07 & 0.01 & -0.18 \\
\hline I.4 & $5-\mathrm{C}_{2} \mathrm{H}_{5}$ & -0.30 & -1.87 & -0.15 & -0.07 & 0 & -0.15 \\
\hline $\mathbf{I . 5}$ & $5-\mathrm{nC}_{3} \mathrm{H}_{7}$ & -0.23 & -1.87 & -0.13 & -0.07 & 0.01 & -0.14 \\
\hline I.6 & $5-\mathrm{Cl}$ & -0.17 & -2.02 & 0.23 & 0.37 & 0.42 & -0.19 \\
\hline I.7 & $5-\mathrm{Br}$ & -0.16 & -2.02 & 0.23 & 0.39 & 0.45 & -0.22 \\
\hline $\mathbf{I . 8}$ & $5-\mathrm{CN}$ & -0.15 & -2.04 & 0.66 & 0.56 & 0.51 & 0.15 \\
\hline 1.9 & $5-\mathrm{NO}_{2}$ & -0.14 & -2.30 & 0.78 & 0.71 & 0.65 & 0.13 \\
\hline II.1 & $\mathrm{H}$ & -0.29 & -2.00 & 0 & 0 & 0 & 0 \\
\hline II.2 & $5-\mathrm{CH}_{3}$ & -0.30 & -2.00 & -0.17 & -0.07 & 0.01 & -0.18 \\
\hline II.3 & $5-\mathrm{C}_{2} \mathrm{H}_{5}$ & -0.24 & -2.00 & -0.15 & -0.07 & 0 & -0.15 \\
\hline II.4 & $5-\mathrm{Cl}$ & -0.19 & -2.07 & 0.23 & 0.37 & 0.42 & -0.19 \\
\hline II.5 & $5-\mathrm{NO}_{2}$ & -0.06 & -2.13 & 0.78 & 0.71 & 0.65 & 0.13 \\
\hline III.1 & $\mathrm{H}$ & -0.28 & -1.92 & 0 & 0 & 0 & 0 \\
\hline III.2 & $5-\mathrm{CH}_{3}$ & -0.29 & -1.92 & -0.17 & -0.07 & 0.01 & -0.18 \\
\hline III.3 & $5-\mathrm{C}_{2} \mathrm{H}_{5}$ & -0.30 & -1.91 & -0.15 & -0.07 & 0 & -0.15 \\
\hline III.4 & $5-\mathrm{Cl}$ & -0.26 & -2.01 & 0.23 & 0.37 & 0.42 & -0.19 \\
\hline III.5 & $5-\mathrm{NO}_{2}$ & -0.16 & -2.19 & 0.78 & 0.71 & 0.65 & 0.13 \\
\hline
\end{tabular}

(a) Valores determinados por voltametria cíclica em DMF, utilizando-se TEAP como eletrólito suporte e eletrodo de Ag/AgI/TBAI como referência. Os valores apresentados são valores médios de pelo menos três determinações, com desvios padrão menores que $0.01 \mathrm{~V}$.

(b) Valores calculados usando o método semi-empírico AM1

(c) Valores de literatura,

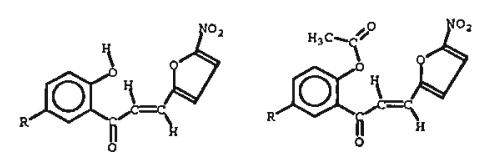

Série II 


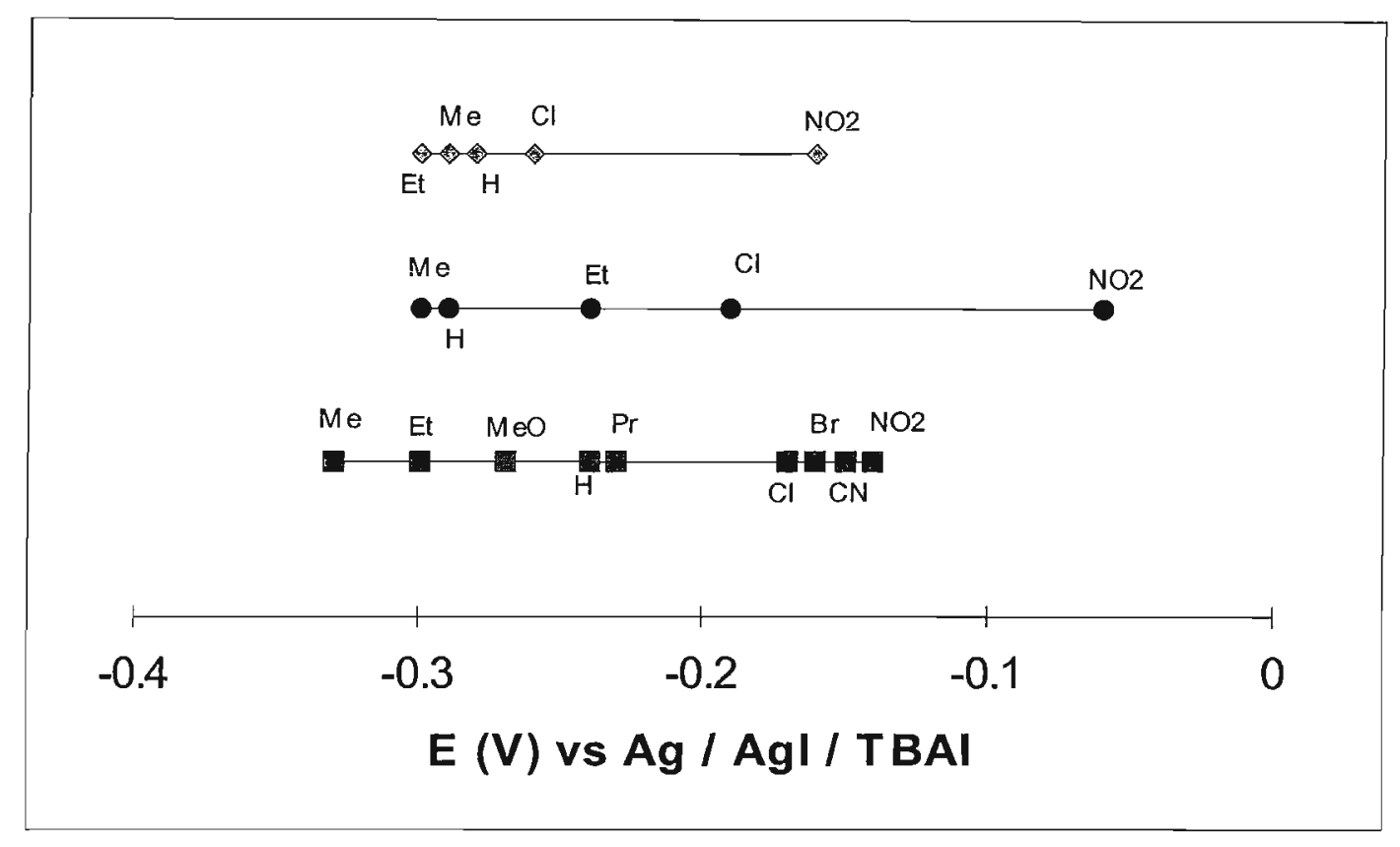

Figura II.1.2-3 Faixas de potencial de redução (primeira etapa), obtidos por voltametria cíclica para os compostos das séries I (অ) II (•) e III( $\diamond)$, respectivamente.

Os derivados nitrofurânicos estudados neste trabalho, compostos das séries I, II e III, possuem potenciais de redução (medidos por voltametria cíclica, para a primeira etapa de transferência de elétrons variando na faixa entre -0.33 a $-0.06 \mathrm{~V}$, dependendo do efeito do substituinte. Esta faixa varia pouco de série para série quando comparado com outros nitroheterocíclicos. 


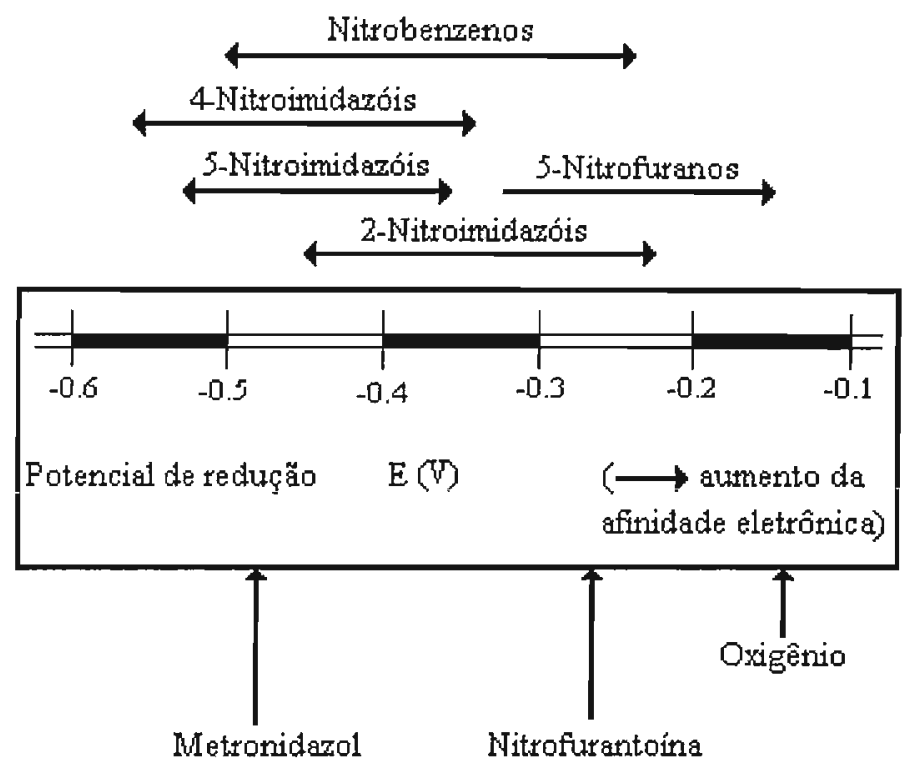

Figura II.1.2-4 Representação esquemática das faixas de potenciais de redução (E) para as diferentes classes de compostos nitro-heterocíclicos e nitrobenzênicos. $O$ oxigênio é a espécie biológica com maior afinidade eletrônica (mais prontamente redutível) e drogas de potencial de redução mais baixos (mais negativos) são menos prontamente redutíveis.

As equações e gráficos de correlação do potencial de redução medido para os compostos das séries IV.I a IV.III versus a contante $\sigma_{m}$ do substituinte ou versus os valores de energia dos orbitais LUMO, calculadas pelo método AM1 são apresentados respectivamente nas Figuras II.1.2-5 e II.1.2-6. 


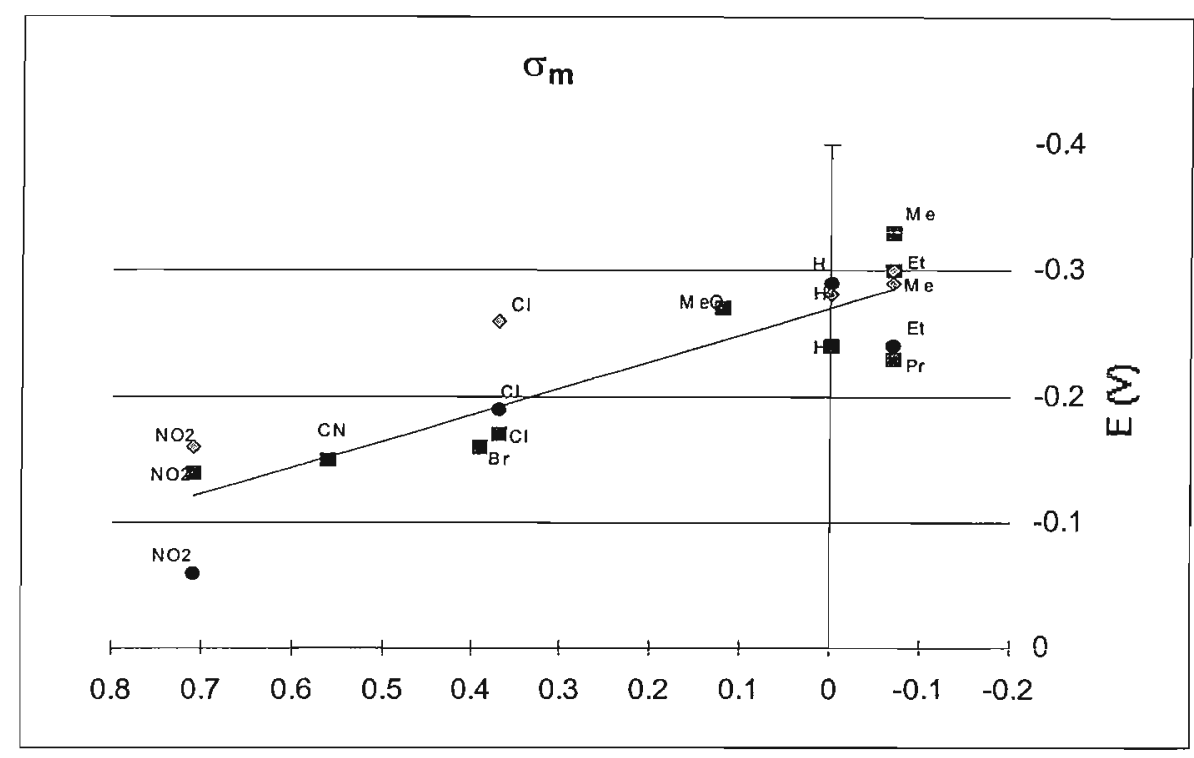

$$
\begin{aligned}
& \mathrm{E}=0.21( \pm 0.05) \sigma_{\mathrm{m}}-0.27( \pm 0.02) \\
& (\mathrm{n}=19 ; \mathrm{r}=0.881 ; \mathrm{s}=0.035 ; \mathrm{F}=59.4)
\end{aligned}
$$$$
\text { eq. II.1.2 }-4
$$

Figura II.1.2-5. Correlações entre os valores do potencial de redução, $\underline{\mathbf{E}}$, obtidos por voltametria cíclica em DMF, utilizando-se TEAP como eletrólito suporte e eletrodo de Ag/AgI/TBAI como referênica, versus o valores da constantes eletrônica $\left(\sigma_{m}\right)$ dos substituintes retirados da literatura, para os compostos das séries IV.I, IV.II e IV.III. 


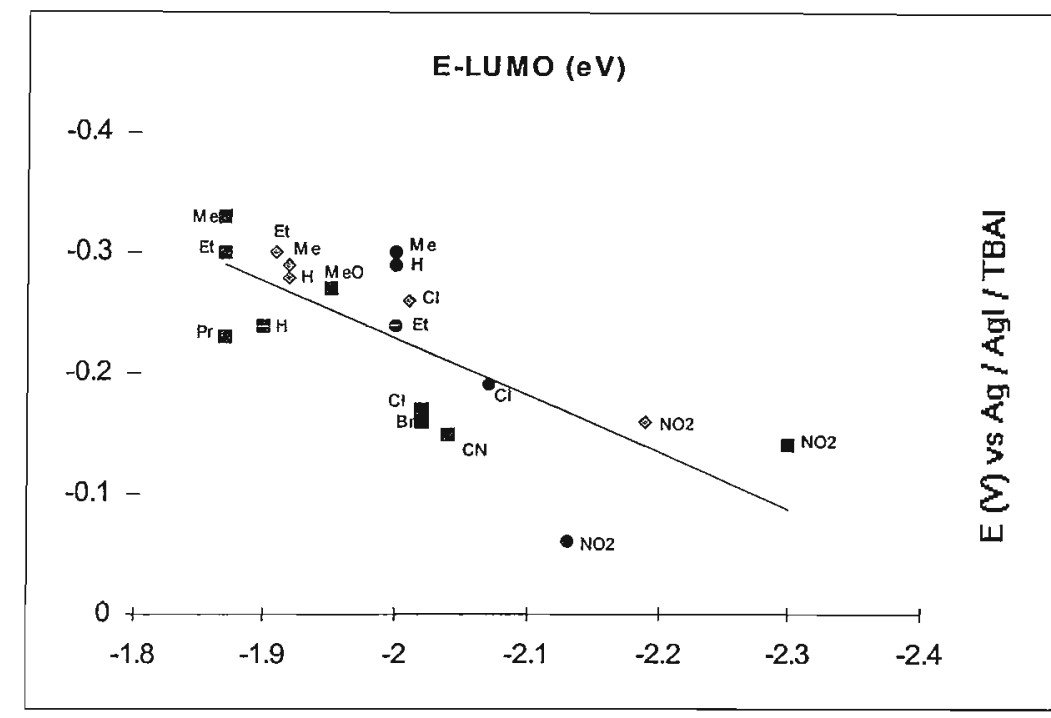

$$
\begin{aligned}
& E=-0.47( \pm 0.22) E \text {-LUMo }-1.18( \pm 0.43) \\
& (n=19, r=0.74, s=0.0503, F=20.71)
\end{aligned}
$$

Figura II.1.2-6. Correlações entre os valores do potencial de redução, E, obtidos por voltametria cíclica em DMF, utilizando-se TEAP como eletrólito suporte e eletrodo de Ag/AgI/TBAI como referênica, versus os valores de energia dos orbitais LUMO, calculados pelo método AM1, para os compostos das séries IV.I, IV.II e IV.III.

Deste estudos resultou tese de doutorado de José Ricardo Murari Pires (ANEXO DII) e em 02 publicações com corpo editorial (ANEXO VI) e (ANEXO VII).

Vale a pena ressaltar a importância desta publicação para o grupo e a sua repercussão despertando interesse do meio produtivo, como já referido em detalhes no memorial.

Atualmente no laboratório, estamos dando continuidade ao estudo desta série de compostos. Assim, como descrito em detalhes no memorial, estamos aplicando métodos quimiométricos para seleção de descritores estruturais para análise $Q S A R$ para a atividade antibacteriana dessaa séries de derivados rígidos e flexíveis de nitrofuranos 5substituídos (DOC 9.3.6.1-50.) Esses projetos estão sendo desenvolvidos em colaboração com o Prof. Dr. Roy Bruns e Ricardo Haiduke, seu aluno de doutorado na Unicamp. 


\section{Parâmetros estéricos e parâmetros relacionados à refratividade molar}

Os parâmetros estéricos dos substituintes são medidas dimensionais, ou geométricas, da molécula toda ou dos substituintes, relacionados com tamanho e forma (KUBINYI, 1993).

Os parâmetros relativos as propriedades relacionadas ao volume do composto são descritas com dificuldade, pois a estrutura 3D dos alvo biológico (sítios de ligação) dos compostos na maioria das vezes não é conhecida. O primeiro parâmetro estérico usado em estudos de $Q S A R$ foi a constante estérica do substituinte $\mathbf{E}_{\mathbf{s}}$. Muitos outros parâmetros (KUBINYI, 1993) relacionados com o tamanho e/ou forma, por exemplo, volumes de van der Waals, volumes molares área acessível ao solvente, refratividade molar, parâmetros STERIMOL: L, $\mathrm{B}_{1}, \mathrm{~B}_{2}, \mathrm{~B}_{3}$ e $\mathrm{B}_{4}$, entre outros, têm sido usados para descrever efeitos estéricos (KUBINYI, 1993; HANSCH, 1995).

Para série de compostos análogos da procaína, com substituintes na posição orto, série Ib, o sistema resultante se tornou interessante do ponto de vista estrutural, através da a análise da(s) natureza(s) da transmissão do(s) efeito(s) eletrônico(s) transmitido pelo substituintes sobre sobre $\boldsymbol{V}_{\mathbf{C}=\mathbf{0}}$ bem como o efeito de grupos volumosos. Assim estes foram expressos pelo parâmetro $\mathbf{E}_{\mathbf{s}}(\mathbf{A M D})$, proposto por Fujita e colaboradores (SOTOMATSU, 1990), tornando as correlações significativas.

Dentre as propriedades que estão relacionadas à polarizabilidade, a refratividade molar MR é bastante utilizada em estudos de $Q S A R$, embora a sua natureza não esteja totalmente esclarecida. Esta dificuldade se deve ao fato de MR ser um parâmetro que pode estar relacionado à outras propriedades como lipofilicidade e às relativas ao volume (DEARDEN et al, 1991; KUBINYI, 1993; HANSCH, 1995).

\section{II.2. Abordagens Metodológicas em $Q S A R / Q S A R-3 D$ Introdução}

Até o início dos anos sessenta encontram-se, na literatura, inúmeros trabalhos apresentando estudos de relações entre a estrutura química e a resposta biológica sem, no entanto, abordar aspectos quantitativos dessas correlações. Em 1964, C. Hansch e T. Fujita (KUBINYI, 1993) propuseram uma abordagem, que se mostrou adequada para o estudo quantitativo das relações entre a estrutura química e a atividade biológica, $Q S A R$, dando início a um novo ramo de estudo na pesquisa científica. A partir desta 
data, diversas estratégias metodológicas foram desenvolvidas, na área $Q S A R$, visando propor modelos descrevendo de modo quantitativo a dependência da atividade biológica em termos da estrutura do composto.

Dentre os modelos propostos, citam-se aqueles que descrevem a atividade biológica através de parâmetros físico-químicos e/ou estruturais (análise de Hansch); como através de variáveis descritoras das diferentes características estruturais do composto (análise de Free-Wilson). Encontram-se também modelos utilizando como descritores os perfís moleculares tridimensionais relativos as propriedades dos compostos responsáveis pela atividade. Atualmente, as metodologias desenvolvidas para a análise das relações entre estrutura-atividade juntamente com a modelagem molecular são muito utilizadas, descrevendo de modo quantitativo, as relações entre a estrutura química das moléculas e sua(s) atividade(s) biológica(s), QSAR/QSAR-3D.

$\mathrm{Na}$ literatura encontram-se inúmeras revisões, sendo particularmente importantes aquelas que discutem suas limitações e alcances, apresentando deste modo uma visão crítica das diversas abordagens (KUBINYI, 1993; KUBINYI 1998; HANSCH, 1990; HANSCH, 1995; MARTIN, 1998).

\section{II.2.1.Abordagem extratermodinâmica (Abordagem de Hansch-Fujita)}

A abordagem tradicional de Hansch-Fujita considera que a atividade biológica de um composto, resultado da(s) interação(ões) deste com a(s) diferentes biofase(s) pode ser expressa pela contribuição dos propriedades físico-químicas ou estruturais, identificadas como sendo responsáveis pela atividade ou resposta biológica (FUJITA, HANSCH, 1990; KUBINYI, 1995; KUBINYI, 1993; HANSCH, LEO, 1995; SEYDEL, SCHAPER 1979; MARTIN, 1978; AMARAL, et al., 1991; AMARAL et al., 1993; AMARAL et al., 1995; AMARAL et al., 1997; PIRES, 2001).

Pela análise de Hansch ou abordagem extratermodinâmica, a atividade biológica (ou resposta biológica) pode, então, ser expressa como função de parâmetros estruturais, respectivamente, lipofílicos, eletrônicos/polares, hidrofóbicos, estéricos e de dispersão. Como já referido nesta tese, a aplicação desta abordagem envolve tanto a proposição de modelo matemático bem como a medida, ou o cálculo, dos parâmetros responsáveis pela atividade e de suas contribuições relativas para a mesma. A análise subseqüente dos resultados permite verificar tanto a validade, limitações bem como o poder de 
previsão do modelo proposto. O grau de complexidade do modelo empregado, além da interação per se, dependerá de quão exatamente essas interações podem ser expressas ( KUBINYI,1979; HANSCH, et al 1990; KUBINYI, 1993; HANSCH et al., 1995; AMARAL et al, 1997; PIRES, 2000; PIRES 2001).

Há quase quatro decadas décadas quase todas as combinações imagináveis de parâmetros de naturezas lipofilica, estérica, eletrônica e relacionada à polarizabilidade, com ou sem variáveis indicadoras adicionais têm sido utilizadas para descrever distintas atividades biológicas (ou respostas biológicas) através de equações de correlação, expressas nas suas formas linear, parabólica e bilinear.

Apresento a seguir as regras para obtenção de modelos propostas por Unger e Hansch sendo estas criticamente comentadas por Kubinyi em um de seus livros (KUBINYI, 1993) e recententemente sumarizadas em uma publicação do grupo (ANEXO DII).

1. Seleção de variáveis independentes: Uma grande faixa de parâmetros de diferentes naturezas deve ser testada, como $\log P$ ou $\pi, \sigma$, MR e parâmetros estéricos. Parâmetros obtidos por cálculos de orbitais moleculares bem como Variáveis Indicadoras não devem ser superestimados. Existem, no entanto, problemas ao se testar muitas variáveis. Os parâmetros escolhidos para a "melhor equação" devem ser essencialmente independentes, ou seja, o coeficiente de intercorrelação $r$ não deve ser maior que 0,6-0,7, exceção é a combinação de termos lineares e quadráticos, como $(\log P)^{2}$ e $\log P$, que usualmente são altamente intercorrelacionados, com $r>0.9$.

2. Justificativa da escolha de variáveis independentes. Todos os parâmetros "razoáveis" devem ser validados por procedimento estatístico adequado, como por exemplo, análise de regressão, teste $\mathrm{F}$, (sendo atualmente a validação cruzada bastante recomendada). A melhor equação é normalmente a equação com o menor desvio padrão, sendo todos os termos significativos(indicado pelos intervalos de confiança de $95 \%$, ou pelo teste $\mathrm{F}$ seqüencial). Alternativamente, a equação com o maior valor de $\mathrm{F}$ pode ser selecionada como a melhor equação.

3. Havendo mais de uma equação com mesmo nível de confiança estatística, a mais simples, com menos parâmetros, deve ser a escolhida. 
4. Número de termos. Deve se ter no mínimo 5 a 6 dados (compostos) por variável para se evitar correlações casuais. (Esta regra se aplica apenas à conjuntos de dados de tamanho intermediário; para conjuntos de dados pequenos, mais parâmetros podem ser incluídos se estes se baseiam em um modelo razoável. Para grandes conjuntos de dados, por exemplo, números de compostos $>30$, esta recomendação conduz à equações que incluem muitas variáveis).

5. Modelo qualitativo. É importante ter um modelo qualitativo que seja consistente com o processo físico-orgânico-bioquímico em consideração.

Em nosso laboratório, estas recomendações foram considerados na proposição dos modelos de $Q S A R$ estudados. Suas implicações e consegüências para implementação e otimização de cada metodologiaa para obtenção de parâmetros estruturais, em especial dos parâmetros lipofílico e eletrônico, foram discutidas anteriormente neste texto, especificamenrte e no ítem "algumas considerações sobre as metodologias empregadas". Em relação a obtenção de dados de parâmetros biológicos adequados incluindo uma larga faixa de variação para que apresente validade estatística e significado biológico - teve sérias implicações na condução de nossos projetos, como. apresentado em detalhes no memorial.

Topliss foi o primeiro a investigar de maneira sistemática o risco de correlações ao acaso na análise de Hansch. Várias simulações, usando números gerados de forma aleatória, revelaram que para um dado número de compostos a chance de se obter correlações com coeficiente de correlação acima de 0,9 não apenas drasticamente aumenta com o número de variáveis incluídas na equação, mas também com o número de variáveis, a partir das quais as diferentes combinações de variáveis são selecionadas (TOPLISS, COSTELLO, 1972; RANDO, et al, 2002).

Esta estratégia proposta por Topliss, incluindo-se o esquema de seleção de compostos, conhecido como árvore de Topliss, se torna, particularmente interessante quando o número de compostos disponíveis para a análise é reduzido, ou não é suficiente para aplicar o modelo clássico. Esta dificuldade podendo advir de diferentes razões, incluindo-se etapas de síntese muito demoradas. 
Utilizando esta estratégia metodológica para seleção de compostos, em um trabalho em colaboração (ANEXO XII) nosso laboratório determinou os valores do coeficiente de partição de séries de compostos com atividade tuberculostática.

Os fatores importantes para a significância e a validade de modelos propostos em QSAR foram revisados em várias publicações (KUBINYI, 1993; PLEISS, UNGER, 1990; HANSCH, 1990; HANSCH, 1995).

\section{II.2.2.Abordagens de Free-Wilson e mista (Hansch e Free-Wilson)}

A abordagem de Free-Wilson (FUJITA, 1990; KUBINYI, 1990; KUBINYI, 1993) é o verdadeiro modelo de estrutura-atividade. Para uma série de compotos, uma Variável Indicadora é gerada para cada característica estrutural que é modificada na série, selecionado-se arbitrariamente um dos compostos como referência. Valores respectivamente iguais a 1 - indicando a presença de um certo substituinte ou característica estrutural - e iguais a 0 - indicando sua ausência - são correlacionados com os valores de atividade biológica por análise de regressão linear múltipla. Os valores dos coeficientes de regressão obtidos para cada variável indicadora são as contribuições de cada elemento estrutural correspondente para a atividade biológica. $\mathrm{O}$ modelo gerado pode ser denominado como "Modelo matemático", "modelo de aditividade" e "abordagem de novo" sendo estes sinônimos para o método de FreeWilson.

A versão proposta por Fujita e Ban (KUBINYI, 1990) é uma aplicação simples do conceito de aditividade de contribuição de grupos para os valores de atividade biológica. Atualmente apenas esta modificação é utilizada.

Devido à relação existente entre a análise de Hansch e o modelo de Free-Wilson, variáveis indicadoras foram incluídas nas análises de Hansch. Os dois modelos podem ser combinados em uma abordagem mista, nas formas linear ou não-linear, o que oferece as vantagem de ambas as abordagens e aumenta a aplicabilidade das relações quantitativas entre estrutura-atividade(MARTIN, LYNN, 1971; AMARAL, MIYAZAKI, TAVARES et al., 1995; PIRES et al., 2001).

Em nosso laboratório, são muitos os exemplos onde aplicamos a abordagem mista. Assim, introduzimos Variáveis Indicadoras, relativa à determinada característica estrutural, até que se tenha um parâmetro válido para decrever tal interação. 
$\mathrm{E}$, de modo análogo em nosso laboratório utilizamos $\left(\mathbf{I}_{\text {orto }}\right)$ para descrever o(s) efeito(s) de substituintes nas posições orto de séries de derivados da procaína (neste texto classificadas como série Ib) sobre dados espectroscópicos ou parâmetros hidrofóbicos. A interpretação desta variável foi feita a posteriori, a partir dos resultado semelhantes observados ao se incluir o parâmetro estérico proposto por Fujita (E) $\mathbf{E}_{\mathbf{s}}$ (AMD). (ANEXO II).

No laboratório, mais recentemente, aplicamos a abordagem mista, utilizando numa primeira etapa uma Variável Indicadora para descrever a contribuição da(s) característica(s) estrutural(is), não expressas por um único parâmetro estrutural, procurando, em uma segunda etapa esclarecer o significado desta Variável Indicadora.

Assim, para séries de derivados da procaína e da procainamida, (neste texto classificadas como séries I e II), a toxicidade aguda pode ser descrita pela introdução da Variável Indicadora, $\mathrm{I}_{(\mathrm{OCOCH} 2)}$. (ANEXO III, equação 3).

$$
\begin{aligned}
& \log \left(1 / L D_{50}\right)=0.22( \pm 0.08) \log P_{a p p}+2.48( \pm 0.13) \quad \text { equação II.2.2-1 } \\
& \mathrm{n}=11 ; \quad \mathrm{r}=0.905 ; \quad \mathrm{s}=0.124 ; \quad \mathrm{F}=40.65 \\
& \log \left(1 / \mathrm{L} D_{50}\right)=0.25( \pm 0.04) \log P_{\text {app }}-0.24( \pm 0.11) \mathrm{r}_{(\mathrm{OCOCH} 2)}+2.44( \pm 0.10) \text { equação II.2.2-2 } \\
& \mathrm{n}=27 ; \quad \mathrm{r}=0.925 ; \quad \mathrm{s}=0.128 ; \quad \mathrm{F}=71.55
\end{aligned}
$$

Para esta série de compostos, a Variável Indicadora $\mathbf{I}_{(\mathbf{O C O C H 2})}$, reflete os efeitos de interações intramoleculares, incluindo aquelas entre os atómos de oxigênio do grupo carboníla e de nitrogênio do grupo dialquilamônio assim como diferentes contribuições da porção hidrofílica da molécula, devido à diferenças nos valores do $\mathrm{pK}_{\mathrm{a}}$, para a lipofilicidade da molécula toda. A inclusão da Variável Indicadora, com contribuição negativa, resultou em uma melhor modelo. A contribuição negativa associada à Variável Indicadora pode ser explicada considerando-se um possível envolvimento da estabilidade do composto (gráu de hidrólise) juntamente com efeitos de proximidade de grupos polares sobre a lipofilicidade.

Assim, nesta etapa da análise e mantendo-se o número de compostos da série $(n=27)$, todos estes efeitos não podem ser expressos por um único parâmetro. Estes são, no entanto, expressos pela Variável Indicadora, importante para o prossegumento da 
análise, visando poder posteriormente esclarecer tanto sua contribuição bem como sua natureza.

No laboratório, no tema de doutorado de José Ricardo M. Pires, aplicamos a análise de $Q S A R$ a atividade antimicrobina avaliada contra as bactérias Gram-positiva: Staphylococcus aureus (ATCC-25923) e Gram-negativa: Caulobacter crescentus (NA1000) para 19 derivados nitrofurânicos 5-substituídos incluindo análogos contendo o anel benzofurânicos (série IV.I, $n=9$ ) e, os correspondentes análogos flexíveis (séries IV-II e IV-III; n=10), neste texto classificados como série IV. Para se poder expressar a atividade das três séries estudadas em uma única equação (modelo QSAR) fez-se necessário a introdução da variável indicadora $\mathbf{I}_{\mathbf{a b s}}$, indicando a presença ou ausência do anel benzofurânico na estrutura. Para os compostos das três séries a aplicação da análise de $Q S A R$ mista indicou uma contribuição negativa do termo eletrônico para as atividade antibacteriana avaliada respectivamente contra Staphylococcus aureus e Caulobacter crescentu . Sua interpretação feita posteriormente. (ANEXO VI) (ANEXO VII)(ANEXO XIV)

Ao se introduzir análogos mais flexíveis, os modelos de $Q S A R$ revelam que a atividade antibacteriana contra $S$. aureus é principalmente descrita por dois fatores: um eletrônico (expresso pelas constantes de substituinres $\mathfrak{I}$ e $\mathfrak{R}$ ou por $\underline{\mathbf{E}}$ ) e um segundo fator estérico ou conformacional ( expresso pela variável Indicadora $\mathrm{I}_{\mathrm{abs}}$ ), equação II.2.2-3. Para C. crescentus, modelos similares foram obtidos.

$$
\begin{aligned}
& \log \left(1 / \mathrm{IC}_{50}\right)^{\text {S. aureus }}=-0.8( \pm 0.4) \Im-1.6( \pm 0.7) \Re-1.0( \pm 0.2) \mathrm{I}_{\mathrm{ab}}+3.3( \pm 0.2) \mathrm{II} .2 .2-3 \\
& \mathrm{n}=19 ; \mathrm{r}=0.970 ; \mathrm{s}=0.197 ; \mathrm{F}=78.429 ; \mathrm{r}_{\mathrm{CV}}^{2}=0.905 ; \text { SPRES }_{\text {PR }}=0.246
\end{aligned}
$$

As menores atividades observadas ( 10 vezes ) nas séries IV-II e IV-III observed quando comparadas com série I, para $S$. aureus e C. crescentus, podem ser explicadas considerando os requisitos conformacionais não satisfeitos nas primeiras duas. Nas três séries, considerando os mesmo substituintes, as variações observadas nos valores do potencial de redução bem como de outras parâmetros físico-químicos são pequenas, para poderem explicar as diferenças observadas nas atividade biológicas. As explicaçòes esclarecedoras, só são otidas com os modelos CoMFA ou $M S A$, que nos permite fornecer uma interpretação físico-química desta variável Indicadora, no modelo QSAR (ANEXO 
VI) (ANEXO VII). As correspondentes análises QSAR serão apresentadas e discutidas no CAPÍTULO III.2.

Sets IV (I,II and III):

$$
\begin{aligned}
& \log \left(1 / \mathrm{IC}_{50}\right)^{\text {S. aureus }}=-0.82( \pm 0.38) \mathfrak{I}-1.59( \pm 0.70) \mathfrak{R}-1.04( \pm 0.21) \mathrm{I}_{\text {abs }}+ \\
& +3.26( \pm 0.20) \\
& \left(\mathrm{n}=19 ; \mathrm{r}=0.970 ; \mathrm{s}=0.195 ; \mathrm{F}=78.429 ; \mathrm{Q}^{2}=0.905 ; \mathrm{s}-\mathrm{PRESS}=0.246\right)
\end{aligned}
$$

equação II.2.2-4

\section{Sets IV (I,II and III):}

$\log \left(1 / \mathrm{IC} \mathrm{C}_{50}\right)^{\text {S. aureus }}=-0.67( \pm 0.20) \Sigma \sigma-1.31( \pm 0.19) \mathrm{I}_{\mathrm{abs}}+3.49( \pm 0.15)$

$\left(\mathrm{n}=19 ; \mathrm{r}=0.968 ; \mathrm{s}=0.195 ; \mathrm{F}=117.428 ; \mathrm{Q}^{2}=0.909 ; \mathrm{s}-\mathrm{PRESS}=0.233\right)$

equação II.2.2-5

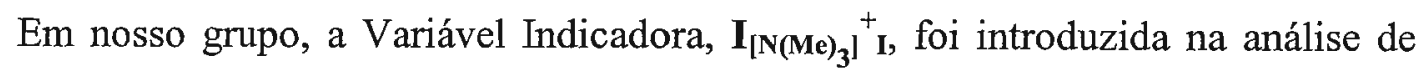
$Q S A R$ para descrever a citotoxicidade de duas séries de derivados de bases de Mannich, a saber: nove cloretos de 3-(dimetilamino)-propiofenonas-4-X-substituidas e, seis iodetos de 3-(trimetilamino)-propiofenonas-4-X-substituídas correspondentes e, consta da dissertação de mestrado de Cristiano Raminelli (ANEXO M-6).

Para a análise de $Q S A R$ das suas séries, em um única equação (modelo) foi necessário definir e incluir na análise de $Q S A R$ uma variável indicadora, que expresse as características estruturais que diferenciam as mesmas. Assim, a presença do grupo $\left[-\mathrm{N}\left(\mathrm{CH}_{3}\right)_{3}\right]^{+} \mathrm{I}^{-}$, foi descrita pela variável indicadora $\mathbf{I}_{\left[\mathrm{N}(\mathrm{Me})_{3}\right]^{+-}} \mathrm{I}^{+}$que assume os valores iguais a 1 (um) e 0 (zero) para as séries de iodetos e de cloretos, respectivamente.

$$
\begin{aligned}
& \log \left(1 / \mathrm{IC}_{50}\right)=-0,56( \pm 0,27) \pi+0,35( \pm 0,29) \mathrm{MR}_{4}+0,23( \pm 0,22) \mathbf{I}_{\left[\mathrm{N}(\mathrm{Me})_{3}\right]}{ }_{\mathrm{I}}^{+}+1,53( \pm 0,22) \\
& \left(\mathrm{n}=15 ; \mathrm{r}=0,82 ; \mathrm{s}=0,18 ; \mathrm{F}=7,64 ; \mathrm{Q}^{2}=0,43 ; \text { SPRESS }=0,24\right) \quad \text { equação. II.2.2-5 }
\end{aligned}
$$

A presença do grupo $\left[-\mathrm{N}\left(\mathrm{CH}_{3}\right)_{3}\right]^{+}\left[\mathrm{I}^{-}\right.$poderia promover interações intramoleculares, que poderiam afetar tanto a lipofilicidade como a distribuição eletrônica desta série de compostos, que estariam contribuindo para modular a citoroxicidade. Adicionalmente, no modelo resultante, expresso pela equação II.2.2-5, observa-se um pequeno valor positivo $(+0,23)$ associado à variável Indicadora. Assim, pode-se, ainda preliminarmente/ especulativamente, sugerir que o grupo $\left[-\mathrm{N}\left(\mathrm{CH}_{3}\right)_{3}\right]^{+} \mathrm{I}^{-}$ 
presente poderia estar promovendo por uma reação de eliminação (tipo Hofman) a formação de cetonas $\alpha, \beta$-insaturadas, sendo estas reconhecidas por apresentar propriedades citotóxicas/anticâncer.

Concluindo: No estudo das interações do complexo sistema bológico, a aplicação da abordagem mista - Hansch-Free-Wilson - pode fornecer informações relevantes sobre o sistema com a vantagem de se manter o número de compostos da série, não tendo de se incluir mais compostos. A análise dos resultados pode gerar hipóteses que necessitam ser, numa segunda etapa, comprovadas.

A abordagem tradicional tem seu papel importante no planejamento de moléculas bioativas, em especial de fármacos, apesar de não considerar o arranjo tridimensional dos grupos. Como destacado anteriormente, esta permite, no entanto, elucidar o papel de propriedades físico-químicas ou estruturais responsáveis pelas interações composto-alvo biológico, entender o efeito da lipofilicidade e da ionização sobre o transporte ou a distribuição do fármaco no sistema biológico; introduzir e esclarecer o conceito de lipofilicidade ótima no transporte passivo de determinado fármaco, como por exemplo na absorção gastrintestinal ou na passagem através da barreira hematoencefálica (KUBINYI, 1993; ABRAHAM et al., 1994; MALVEZZI et al., 2001). Neste texto, alguns destes aspectos já foram apresentados e discutidos, em particular, ao se discutir a importância do estudo dos parâmetros hidrofóbicos, de moléculas candidatas à fármacos, já nas etapas iniciais do planejamento de um fármaco (ou agrotóxico).

\section{Planejamento de séries de compostos em estudos de $Q S A R$}

Uma dos pré-requisitos mais importantes em uma análise de QSAR é o planejamento da série de compostos. Assim, a série de compostos deve ser congênere, ou seja, todos devem possuir o mesmo mecanismo de ação, condição que não é fácilmente conseguida. No entanto, pelas análises de $Q S A R$ descritas na literatura é comum o relato de séries de compostos contendo a mesma estrutura base, nas quais a variação estrutural é feita apenas em uma, ou em várias posições, desta estrutura fundamental (KUBINYI, 1993).

Entendemos desta exigência o seguinte: Uma série de compostos será considerada congênere, qquando a etapa determinante da resposta biológica for a mesma para toda a série considerada. Esta interpretação, auxilia inclusive a seleção do parâmetro biológico mais adequado. Pressupõe-se, deste modo, que este parâmetro reflita somente as 
mudanças introduzidas na estrutura. Em outras palavreas, considerando as limitações experimentais, inerentes à cada sistema, tanto os parâmetros biológicos como os estruturais, devem refletir somente as mudanças introduzidas.

Uma vez que as relações entre a estrutura e a atividade (resposta) biológica envolvem muitas interações físico-químicas de naturezas e grandezas diferentes, os modelos de $Q S A R$ são freqüentemente multiparamétricos. Assim intercorrelação entre os parâmetros físico-químicos em séries mal planejadas é um problema que deve ser evitado em estudos de $Q S A R$.

A primeira contribuição para a solução deste problema foi proposta por Craig (CRAIG, 1971). Este considerou o estudo de gráficos 2D de propriedades físicoquímicas, dos substituintes selecionados (por exemplo $\sigma$ versus $\pi$, e $\pi$ versus MR), sugerindo a escolha de substituintes distribuídos nos quatro quadrantes destes gráficos 2D. Este método gráfico é fácil de ser aplicado e diferentes combinações de propriedades físico-químicas podem ser investigadas.

Em nosso laboratório, iniciamos a análise de $Q S A R$ da toxicidade aguda de derivados da procaína, estudando uma série de 12 cloretos de [2-benzoiloxietil]dimetilamônio, para-substituídos, sendo eles: $\mathrm{H} ; \mathrm{CH}_{3} ; \mathrm{C}_{2} \mathrm{H}_{5} ; \mathrm{nC}_{3} \mathrm{H}_{7} ; \mathrm{nC}_{4} \mathrm{H}_{9} ; \mathrm{tC}_{4} \mathrm{H}_{9}$; $\mathrm{OCH}_{3} ; \mathrm{nOC}_{4} \mathrm{H}_{9} ; \mathrm{COCH}_{3} ; \mathrm{Cl} ; \mathrm{NO}_{2} \mathrm{CN}$ (nesta tese nomeados como série Ia) (ANEXO I). Esta série de compostos, apresenta, no entanto, intercorrelação entre os parâmetros físico-químicos analisados, não permitindo distinguir as suas contribuições como sendo de natureza puramente lipofílica, ou relacionada à refratividade molar (MR). Em uma publicação posterior, (ANEXO IV) este problema foi parcialmente solucionado, pois incluímos na série mais 4 compostos (derivados), para-substituídos, sendo eles:: $\mathrm{nC}_{6} \mathrm{H}_{13} ; \mathrm{nOC}_{6} \mathrm{H}_{13} ; \mathrm{SO}_{2} \mathrm{CH}_{3} ; \mathrm{CF}_{3}$. Estes substituintes foram selecionados de modo a diminuirmos a intercorrelação observada anteriormente e, aumentarmos simultaneamente a faixa de variação do parâmetro lipofílico. Mas memo assim, para que a colinearidade fosse minimizada, na análise final foi necessário excluirmos o 4-hexiloxiderivado, embora este possa contribuir muito para a proposição do modelo, por ser bastante um composto bastante lipofilico $(\log P \sim 4)$. Assim, os valores de $\mathrm{r}^{2} \mathrm{da}$ matriz de intercorrelação, originalmente da série original apresentados na (tabela VI do ANEXO IV) ficaram iguais a: $0.350\left(\log P v s v_{\mathrm{C}=0}\right) ; 0.469(\log P v s \sigma) ; 0.447(\log P v s$ 
$\mathfrak{I})$ and $0.223(\log P$ vs $\mathfrak{R})$. Ainda mais, nas equações de correlação foram incluídos somente 15 compostos, como pode ser verificado nas equações 9 e 10 (ANEXO IV).

Em nosso laboratório, mais recentemente, na dissertação de mestrado de Alberto Malvezzi os critérios sugeridos por Craig (CRAIG, 1971) foram aplicados, de modo análogo. Assim, a partir de trabalhos de Scherrer (SCHERRER, 2001) procurou-se construir série de compostos, nas quais as correlações entre a resposta biológica e os valores do coeficiente de partição das espécies ionizada $\left(\log P_{i}\right)$ e não ionizada $\left(\log P_{\mathrm{n}}\right)$ não fossem estatisticamente idênticas. $\mathrm{Na}$ série planejada, a intercorrelação entre os parâmetros hidrofóbicos $\log P_{i}$ de $\log P_{\mathrm{n}}$, seria minimizada, visando modelar a contribuição relativa das formas catiônica e neutra, e assim determinar qual a espécie responsável pela atividade bloqueadora neuromuscular dos derivados da procaína.

Em uma publicação posterior Dearden (DEARDEN et al., 1991) salientou que os valores de $M R$ podem representar as forças de dispersão que contribuem para a interação entre o composto e o alvo biológico. Nesses casos, são esperados valores positivos para o coeficiente do termo relativo a polarizabilidade $M R$. Alternativamente os valores de $M R$ podem representar uma medida do volume do ligante e refletir o impedimento estérico da interação deste com o receptor, e nesse caso são esperados valores negativos para o coeficiente do termo $M R$. Naturalmente pode haver uma combinação dos dois efeitos, o que torna a interpretação da relação ainda mais complexa. Finalmente, o uso adequado do termo relativo a polarizabilidade $M R$ - para descrever a contribuição das forças de dispersão para a interação entre o ligante e o receptor - depende da escolha correta dos substituintes, de modo que seja possível a separação dos efeitos caracterizados pelo termo MR (DEARDEN et al., 1991, KUBINYI, 1993).

Em nosso laboratório estes aspectos foram considerados e na dissertação de mestrado de Wander Alves de Souza (ANEXO M-4), planejamos uma série, incluíndo-se 16 análogos da procaína, com substituintes na posição meta, agrupados nesta tese como série Ic. No planejamento, foram escolhidos dezessesis substituintes, que apresentam intercorrelações não significativas $(r \leq 0.39)$ dos parâmetros. Nesta série, 
observa-se que a equação que melhor descreve os resultados, inclui dois termos um lipofilico e outro relacionado a refratividade molar, MR.

$$
\begin{array}{lllll}
\log 1 / \mathrm{LD}_{50}=+0.13( \pm 0.06) \log P_{\text {app }}+0.21( \pm 0.07) \mathrm{MR}_{3}+2.19( \pm 0.10) & \text { eq. II.2.2-5 } \\
\mathrm{n}=16 \quad \mathrm{r}=0.923 \quad \mathrm{~S}=0.080 \quad \mathrm{~F}=37.480 & \mathrm{r}_{\mathrm{cv}}^{2}=0.766 & \text { S }_{\mathrm{PRESS}}=0.100
\end{array}
$$

No modelo de $Q S A R$ resultante e expresso pela equação II.2.2-5, a análise dos valores dos coeficientes da regressão indicam contribuições positivas tanto de $\log P_{\text {app }}$ como de $\mathrm{MR}_{3}$, para a toxicidade. Deve-se salientar que a contribuição da lipofilicidade para a toxicidade letal é, porém, pequena $(0,13)$. Nesta série de compostos, metasubstituídos, a contrbuição de $\mathrm{MR}_{3}$ para a toxicidade aguda é positiva $(0,21)$. Esta sugere que $\mathrm{MR}_{3}$ esta expressando interações dispersivas ou semi-polares. Um análise comparativa preliminar entre as séries de cloretos de [2-(X-

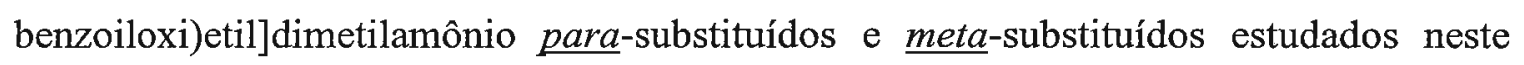
trabalho, sugere, para as duas séries uma contribuição positiva (pequena) de $\log P_{\text {app. }}$. (respectivamente 0,24 e 0,13 ). Uma contribuição positiva de $\mathrm{MR}_{3}$ para a toxicidade letal só foi observada, porém, besta série.

A aplicação de Métodos Quimiométricos, como por exemplo PCA (Análise de Componentes Principais) e Cluster Analysis, na pré-seleção de variáveis, para posteriores estudos de $Q S A R$, garante a não colinearidade entre elas. Em nosso laboratório, em colaboração com Prof. Dr. Roy. E. Bruns, UNICAMP, SP, aplicamos esta abordagem para selecionar variáveis, na série de derivados nitrofurânicos, com atividade antibacteriana, neste texto compilados como séries IV. Os resultados foram apresentados em congresso internacional recente (ANEXO XIV) e, consta de manuscrito em fase final de redação.

Concluindo: Por alguns exemplos de análises QSAR realizadas no laboratório procuramos mostrar como a escolha da série de substituintes é uma das etapas importantes para a análise final do modelo (modelo de QSAR).

Como já referido em detalhes no memorial, no laboratório o estudo da toxicidade letal teve de ser interrompido, no momento, devido a dificuldades na aquisição do parâmetro biológico, $\mathrm{LD}_{50}$. 


\section{Selecão de variáveis em estudos de $O S A R$}

Freqüentemente, vários parâmetros físico-químicos, topológicos ou químicoquânticos (variáveis $\mathrm{X}$ ) são gerados (calculados, medidos ou retirados da literatura). Aqueles que explicam a atividade biológica (variável Y) são selecionados (KUBINYI, 1993, KUBINYI, 1994) para a construção de um modelo (equação de QSAR).

Em muitos casos, a seleção de variáveis é procedimento ambíguo e altamente subjetivo, apesar dos diferentes critérios estatísticos para avaliar os modelos resultantes.

Recentemente, várias publicações têm proposto procedimentos para lidar com este problema. Utilizam-se, freqüentemente, como caso-estudo os dados publicados na literatura, que contêm as atividades biológicas de 31 compostos e 53 variáveis independentes. Mc Farland salientou que "um conjunto de compostos descritos por meras 53 propriedades...envolve $9 \times 10^{15}$ combinações de descritores (sendo $=2^{53}-1$ ). Mesmo que pudessemos analisar estas combinções em um segundo cada, levariamos 285.420.921 anos para chegar a uma conclusão". Embora o número correto de possíveis combinações seja menor $\left(7.16 \times 10^{15}\right)$ porque apenas modelos com, no máximo, 29 variáveis podem ser obtidos para este número de compostos, busca sistemática pelo melhor modelo é realmente impossível.

As estratégias tradicionais para a seleção das "melhores" equações de regressão (KUBINYI, 1993) são descritas na literatura. Mais recentemente, este aspecto foi criticamente revisado. As estratégias atualmente mais amplamente aplicadas para a seleção das melhores equações de regressão: Aproximação por função genética (GFA) utilizando-se um algorítmo genético para gerar os modelos e Algoritimos evolucionários- MUSEUM (Mutation and Selection Uncover Models), recentemente descrito por na literatura (KUBINYI, 1994).

\section{II.2.3. Relações Quantitativas entre Estrutura química e Atividade Biológica em Três Dimensões: $Q S A R 3 D$}

\section{Introdução}

Os métodos desenvolvidos em QSAR e em Modelagem Molecular são, atualmente aplicados, simultaneamente, para descrever de modo quantitativo as interações entre o composto e o sistema biológico, considerando seus aspectos tridimensionais. Esta 
abordagem é denominada $Q S A R-3 D$ e complementa a primeira (KUBINYI, 1993; KIM, MARTIN, 1991; KIM, 1992; PIRES et al., 2000).

A abordagem $Q S A R-3 D$ considera os aspectos estereoquímicos e topológicos das interações ligante-alvo(receptor) biológico. Estes contribuem e, na verdade, muitas vezes, são os fatores determinantes da resposta/atividade biológica

\section{II.2.3.1. $Q S A R 3 D$ quando a estrutura do receptor não é conhecida}

\section{Análise de Forma Molecular (MSA, Molecular Shape Analysis)}

A análise de forma molecular (MSA) (BURKE, HOPFINGER, 1993; HOPFINGER, BURKE, 1990) é um formalismo designado para ser de utilidade prática no planejamento de fármacos com auxílio de computador (CADD, Computer-Aided Drug Design) (PIRES, 1998).

A primeira etapa em $M S A$ envolve a análise conformacional de cada composto investigado. A conformação ativa (bioativa) de um ligante é geralmente entendida como sendo a conformação adotada pelo ligante ao se ligar ao receptor. No entanto, a conformação bioativa, como qualquer outra propriedade estrutural importante de um composto biologicamente ativo em $Q S A R$, corresponde a conformação envolvida na etapa limitante/determinante e, portanto, que está controlando o aparecimento da resposta biológica. Freqüentemente, esta etapa limitante é a formação do complexo ligante-receptor, mas poderia também ser, por exemplo, um passo de ativação/desativação metabólica, um passo de transporte entre membranas, entre outros (KUBINYI, 1993; KUBINYI, 1998). Considerando-se que $M S A$ foi proposta para casos em que a geometria do receptor não é conhecida, toda informação sobre a conformação bioativa deve provir das atividades biológicas observadas e das correspondentes propriedades conformacionais computadas para os ligantes.

As etapas seguintes envolvem a seleção do composto de referência e, a seguir, faz-se a superposição/alinhamento das moléculas. Várias abordagens para o alinhamento das estruturas para comparação molecular têm sido descritas (KLEBE, 1993; ISHIKI et al, 2001). Algumas abordagens baseiam-se nas informações estruturais, que são diretamente retiradas das disposições atômicas. Assume-se que todas as 
moléculas possuem grupos funcionais semelhantes (grupos farmacofóricos), que podem ser trazidos a um arranjo tridimensional semelhante (arranjo farmacofórico). $\mathrm{O}$ método mais intuitivo de alinhamento de moléculas segue um ajustamento interativo de ângulos de torsão com subseqüente superposição por método de mínimos quadrados de átomoschave nos grupos farmacofóricos, utilizando-se computação gráfica. Neste método, pode haver, no entanto, a predisposição do modelador na seleção dos grupos farmacofóricos e no que considera ajuste razoável entre as moléculas. Mais recentemente, algumas abordagens consideram as superfícies de potencial para determinar orientação comum para comparação de moléculas (KLEBE, 1993; ISHIKI, GALEMBECK, AMARAL, 2001), incluindo uma contribuição de nosso laboratório (ANEXO XI).

$\mathrm{O}$ método mais comumente empregado para a determinação de um modelo de $M S A-Q S A R 3 D$ é a regressão linear múltipla. Aspecto único dos modelos gerados por $M S A-Q S A R 3 D$ é que não apenas todas as combinações de descritores moleculares devem ser consideradas na proposição de um modelo ótimo, como também o modelo de $M S A$ deve ser otimizado.

Dentro desta abordagem metodológica, para séries de derivados nitrofurânicos 5substituídos, com atividade antibacteriana, compilados nesta tese, como séries IV, nosso laboratório publicou (ANEXO VII) e constou do tema da tese de doutorado de José Ricardo Murari Pires (ANEXO D-II).

Como discutido anteriormente, para se poder expressar a atividade antibacteriana das três séries estudadas em uma única equação (modelo) fez-se necessário a introdução da variável indicadora $\mathbf{I}_{\mathbf{a b s}}$, indicando a presença ou ausência do anel benzofurânico na estrutura. Com o objetivo de verificar e sugerir hipóteses e interpretações complementares, para o significado da variável indicadora $\mathbf{I}_{\mathbf{a b s}}$, nesta abordagem, $\mathbf{o}$

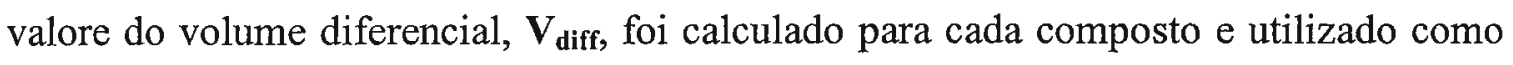
parâmetro estrutural na análise de $Q S A R$. Considerou-se que $\mathbf{V}_{\text {diff }}$ é o volume que cada composto deixa de ocupar no volume ocupado pelo composto de referência. Adicionalmente, esta fornece hipóteses para o fato dos compostos das séries IV.II e IV.III serem menos ativos, do que os compostos da série IV.I, apesar de apresentarem a mesma faixa de potenciais de redução. Deste modo, inclui-se na análise QSAR, também os aspectos conformacionais, interações estéricas e topológicos das moléculas. 
Estes aspectos, embora importantes - particularmente para os derivados flexíveis - não são levados em conta diretamente em QSAR tradicional.

Considerando-se que os compostos da série IV.I são mais ativos do que os correspondentes das séries IV.II e IV.III, o composto IV.I.2 (R=H,série IV.I) foi escolhido como composto de referência para a sobreposição. As estruturas dos demais compostos foram sobrepostas pelo anel nitrofurânico, considerado essencial para atividade antibacteriana. A estrutura do composto de referência, assim como a estrutura de todos os compostos da série IV.I, foram consideradas planares, em sua conformação de menor energia, como demonstrado por busca sistemática. Por outro lado, as estruturas dos compostos pertencentes as séries IV.II e IV.III não podem adquirir uma conformação totalmente planar, observando que o anel benzênico está fora do plano definido pelo anel nitrofurânico.

Para os compostos da série IV.II observa-se a ocorrência de formação de ligação de hidrogênio intra-molecular entre o grupo hidroxila e o grupo carbonila .Este aspecto esta sendo retomado no grupo, em colaboraçãoo com prof. Dr. R. Bruns, INICAMP, SP.

Deste modo, a análise de forma molecular, $M S A$, utilizando o volume diferencial ( $\left.\mathbf{V}_{\text {diff }}\right)$, ou seja, o volume que cada composto deixa de ocupar, no volume ocupado pelo composto de referência, sugere uma interpretação para a variável indicadora $\mathbf{I}_{a \mathfrak{a b s}}$. Assim, pode-se observar, por inspeção visual a região que não é ocupada pelos compostos das séries IV.II e IV.III. A seguir, os valores correspondentes do volume de cada região foram medidos para cada composto, e estão apresentados na Tabela II.2.3.1. Estes valores podem ser interpretados como a falta de ajuste de cada composto.

Para os compostos da série IV.I verificamos na tabela II.2.3.1, que esta medida de volume é aproximadamente zero, enquanto que os compostos das séries IV.II e IV.III possuem todos valores de $\mathbf{V}_{\text {diff }}$ ao redor de $30 \AA^{3}$. Assim, sugerimos que os valores de $\mathbf{V}_{\text {diff }}$ podem substituir a variável indicadora, em todas as equações em que esta foi incluída, já discutido anteriormente nesta tese, sem perder na significância estatística do modelo de QSAR gerado. 
Tabela II.2.3.1 Valores do volume diferencial, $\left(V_{\text {diff }}\left(\AA^{3}\right)\right.$, para os compostos da séries IV.I, IV.II e IV.III, considerado como sendo volume que cada molécula deixa de ocupar no volume ocupado pela molécula de referência $(R=H$, série IV.I)

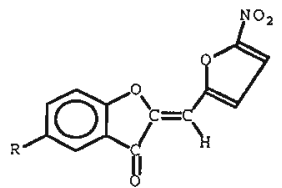

Série IV.I

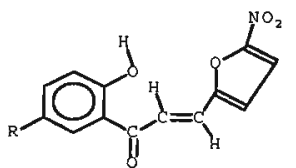

Série IV.II

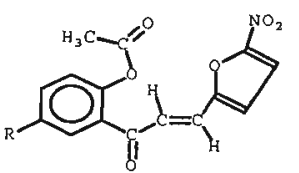

Série IV.III

\begin{tabular}{|c|c|c|c|}
\hline & \multicolumn{3}{|c|}{$\left.\mathbf{V}_{\text {difr }} \mathbf{\AA}^{\mathbf{3}}\right)$} \\
\hline $\mathbf{R}$ & Série IV.I & Série IV.II & Série IV.III \\
\hline $\mathbf{H}$ & 0.0 & 33.3 & 30.6 \\
\hline $\mathbf{M e}$ & 0.7 & 31.5 & 31.3 \\
\hline $\mathbf{E t}$ & 0.7 & 32.0 & 30.5 \\
\hline $\mathbf{n - P r}$ & 0.7 & & \\
\hline $\mathbf{C l}$ & 0.0 & 32.0 & 31.5 \\
\hline $\mathbf{B r}$ & 0.0 & & \\
\hline $\mathbf{M e O}$ & 0.6 & & \\
\hline $\mathbf{C N}$ & 1.9 & & \\
\hline $\mathbf{N O}_{\mathbf{2}}$ & 2.5 & 32.4 & 31.5 \\
\hline
\end{tabular}

As equações obtidas, pelas diferentes abordagens estão apresentadas (ANEXO VII), a seguir:

1. Pela abordagem mista, incluindo $\mathrm{I}_{\underline{a b s}}$ (discutida anteriormente, neste texto):

$$
\begin{aligned}
& \log \left(1 / \mathrm{IC}_{50}\right)^{\text {S. aureus }}=-0.82( \pm 0.38) \Im-1.59( \pm 0.70) \Re-1.04( \pm 0.21) \mathrm{I}_{\mathrm{abs}}+ \\
&+3.26( \pm 0.20) \\
&\left(\mathrm{n}=19 ; \mathrm{r}=0.970 ; \mathrm{s}=0.195 ; \mathrm{F}=78.429 ; \mathrm{Q}^{2}=0.905 ; \mathrm{s}-\mathrm{PRESS}=0.246\right.
\end{aligned}
$$

\section{Pelo cálculo do volume diferencial:}

$$
\begin{gathered}
\log \left(1 / \mathrm{IC}_{50}\right)^{\text {S. aureus }=}-0.76( \pm 0.34) \mathfrak{J}-1.63( \pm 0.74) \Re-0.036( \pm 0.01) \mathrm{V}_{\text {diff }}+ \\
\quad 3.31( \pm 0.18) \\
\left(\mathrm{n}=19 ; \mathrm{I}=0.972 ; \mathrm{s}=0.187 ; \mathrm{F}=85.637 ; \mathrm{Q}^{2}=0.908 ; \mathrm{s}-\mathrm{PRESS}=0.241\right)
\end{gathered}
$$

\section{Abordagem do análogo ativo (The active analog-approach)}

Um método mais objetivo e completo é denominado The active analog-approach (KUBINYI, 1993; MARTIN, 1998), disponível no programa SYBYL(Tripos Inc.). Para séries apresentando pelo menos um composto rígido, com grande atividade, pode-se usar o procedimento de ajuste-flexível múltiplo na etapa de alinhamento. Na série estudada, os grupos farmacofóricos são ligados por "ligações virtuais". A seguir, 
utilizando-se mecânica molecular, as forças adicionais geradas por estas ligações virtuais são simultaneamente minimizadas com respeito ao campo de força intramolecular de cada molécula. Como resultado, as moléculas são forçadas a adquirir orientações similares dos grupos farmacofóricos. No entanto, os resultados dependem, como em qualquer otimização por mecânica molecular, das geometrias de partida. Nenhuma informação sobre o mínimo global ou a existência de uma única solução é fornecida.

\section{Distance-geometry}

Uma outra abordagem, que explora o espaço conformacional para ligar grupos farmacofóricos em uma orientação comum, é chamada distance-geometry (KUBINYI, 1993, MARTIN, 1998). Usando um certo limite de tolerância para superposição de átomos designados como equivalentes, matrizes de distância entre os grupos farmacofóricos são geradas. O algoritmo então aponta conformações comuns a todos compostos que mantêm a mesma distância entre os grupos farmacofóricos. Depois que uma possível orientação comum foi encontrada, as moléculas são individualmente testadas verificando-se se satisfazem a geometria farmacofórica.

\section{$\underline{\text { Análise Comparativa dos Campos Moleculares (CoMFA, Comparative }}$}

\section{Molecular Field Analysis)}

Desde a publicação (CRAMER III, PATTERSON, BUNCE, 1988) a análise comparativa de campos moleculares ( $\boldsymbol{C o M F A}$ ) rapidamente se tornou uma das ferramentas em QSAR-3D mais poderosas e mais utilizadas (CRAMER III et al., 1993)

A abordagem CoMFA correlaciona a atividade biológica com propriedades estruturais em três dimensões representadas pelos campos estéricos e eletrostáticos dos compostos, bem como por propriedades.

No procedimento CoMFA padrão, série de moléculas são selecionadas de acordo com a atividade e modo de ação. As coordenadas tridimensionais destas moléculas são utilizadas nos cálculos de suas propriedades estruturais e eletrônicas, de acordo com métodos computacionais de vários níveis de sofisticação. A seguir, estas moléculas são sobrepostas em suas supostas conformações bioativas, obtendo-se um padrão único de alinhamento (KUBINYI, HAMPRECHT E MIETZNER, 1998). A partir daí, um retículo 
tridimensional é colocado sobre as moléculas sobrepostas, de forma a estabelecer uma caixa regular de vários Angstrons a mais que o volume das estruturas sobrepostas. Em seguida, os campos estéricos e eletrostáticos ao redor destas moléculas são avaliados através de átomos de teste (probe atoms) no retículo retangular de pontos. Átomos de teste ou grupos são dispostos alternadamente nas extremidades do retículo para avaliar as interações de cada campo. Assim, um carbono neutro quantifica interações de van der Walls, uma dada carga avalia as interações eletrostáticas, enquanto doadores ou receptores de átomos de hidrogênio avaliam as possibilidades destes tipos de interações. Este procedimento é realizado para cada molécula e em cada ponto da grade, onde as funções matemáticas utilizadas são os potenciais respectivamente de Lennard-Jones para as interações de van der Walls e o de Coulomb para as interações eletrostáticas. A partir da série original de compostos formam-se dois sub-grupos, quais sejam: um grupo de treinamento do modelo CoMFA e um grupo de moléculas para avaliar as predições do modelo gerado. O resultado da avaliação dos campos em cada ponto do retículo é colocado em uma tabela. A tabela CoMFA-QSAR gerada é analisada pelo método PLS (Partial $L$ east $S$ quares), que não é sensível a co-linearidade dos descritores de campo e fornece o modelo estatístico significativo. A figura II.2.3.1-1 ilustra todo procedimento empregado em COMFA (CRAMER III, PATTERSON, BUNCE, 1988; CRAMER III et al., 1993).

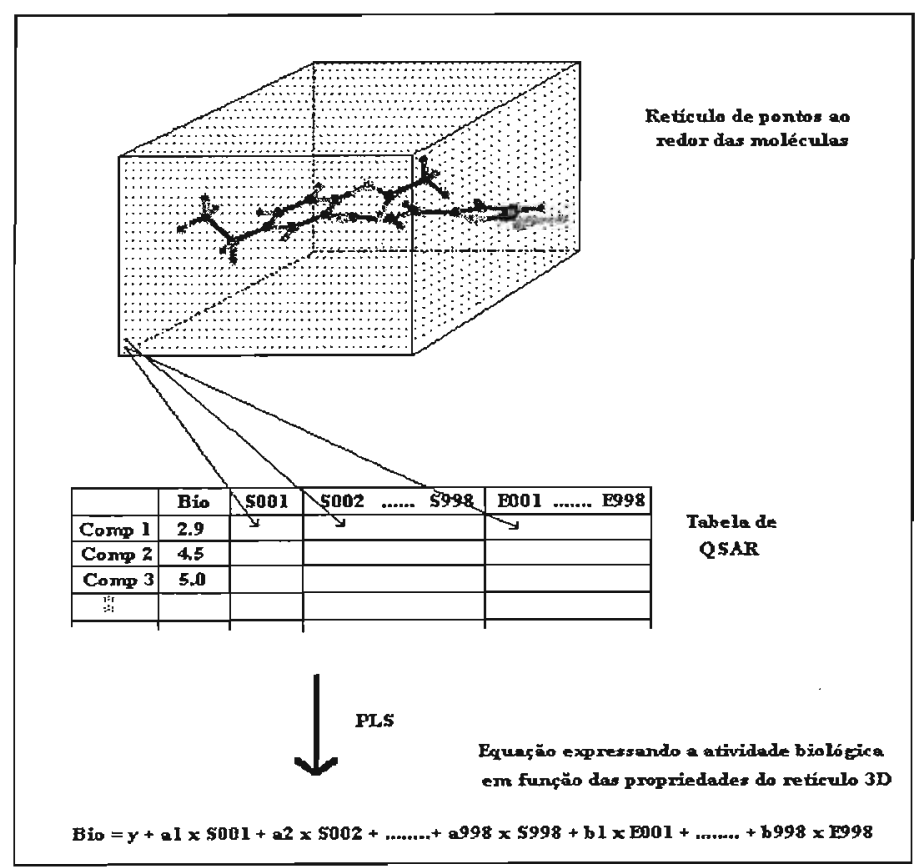

Figura ПI.2.3.1-1 Representação esquemática dos procedimentos empregados na análise comparativa de campos moleculares (CoMFA). 
Os resultados da análise $P L S$ podem ser apresentados na forma de mapas tridimensionais de contorno dos coeficientes, que indicam as regiões do espaço importantes para a atividade biológica. Em CoMFA avançado o potencial lipofilico é também incorporado nos campos de CoMFA, para que se levem em conta também as interações hidrofóbicas (GAILLARD, CARRUPT, TESTA, 1994), bem como os componentes entrópicos não adequadamente descritos pelos campos estéricos e eletrostáticos.

A validação do modelo $C o M F A$ gerado é feita através de validação cruzada. Neste procedimento, um dos compostos da série é deixado fora da análise e faz-se um novo PLS. A equação resultante é, então, usada para prever o valor experimental do composto excluído. Este procedimento é repetido excluindo-se cada um dos compostos, um a um, até que todos os compostos tenham sido excluídos e também preditos. Os valores dos quadrados dos erros de predição, de cada um dos compostos deixado fora da análise, são a seguir acumulados. A soma quadrática dos erros de predição é denominada PRESS (Predictive REsidual Sum of Squares). Para a avaliação da análise global PRESS é normalmente expresso pelo termo $\mathrm{r}^{2}$-validado $\left(\mathrm{q}^{2}\right)$. Em CoMFA, dois valores de $\mathrm{r}^{2}$ são encontrados: $\mathrm{r}^{2}$ convencional é uma medida de quão bem um modelo particular reproduz ou se ajusta aos dados experimentais. Claramente, é mais fácil obter um modelo que reproduza os dados experimentais que um modelo que faça predições corretas. Assim, o valor de $r^{2}$ convencional é sempre maior que o valor de $q^{2}$. A probabilidade de se obter falsos modelos, ou seja, correlações ao acaso por PLS, foi investigada com números aleatórios (KUBINYI, 1993; KUBINYI et al., 1998). Diferentemente do que ocorre com a metodologia de regressão linear múltipla, em que a chance de se obter correlações ao acaso aumenta com o número de variáveis a partir das quais se faz a seleção para construção do modelo (TOPLISS, COSTELLO, 1972) em $P L S$, a possibilidade de se obter correlação ao acaso a partir de variáveis aleatórias não é importante. Adicionalmente, o alinhamento não coerente das estruturas parece conduzir sempre a valores pequenos de $\mathrm{q}^{2}$. A Figura II.2.3.1-2 mostra o resultado gráfico de um estudo de CoMFA.

Interpretação dos resultados de CoMFA: A maioria dos estudos de QSAR termina quando é gerada uma equação linear. Os milhares de termos de um modelo de CoMFA dão ao resultado aparência de expressão intratável, para algum utilização posterior. 
CoMFA, no entanto, tem a "virtude" de que cada coeficiente numérico se dirige, ou se relaciona, diretamente a um ponto no espaço. Assim, considerando-se que cada ponto do retículo retangular possui um coeficiente na expressão de $Q S A R$ e que este coeficiente é implicitamente zero se o ponto for omitido da análise, a equação de $Q S A R$ obtida por CoMFA é usualmente resumida de modo gráfico (mapas de contorno 3D). Deste modo, os poliedros coloridos gerados delimitam volumes ao redor de pontos do retículo dos quais os coeficientes da equação de $Q S A R$ mostram, particularmente, alta associação entre as diferenças nas intensidades dos campos moleculares e a atividade biológica. Tipicamente, haverá dois níveis de contorno para cada campo molecular. Estes realçam as regiões de maior associação, as mais positivas, e aquelas mais negativas. Estes mapas são, freqüentemente, bastante úteis na sugestão de novos compostos com probabilidade de ter maiores valores de atividade biológica. Exemplo ilustrativo aplicado a derivados de nevirapina pode ser observado à Figura II.2.3.1-2. (ANEXO XI). 

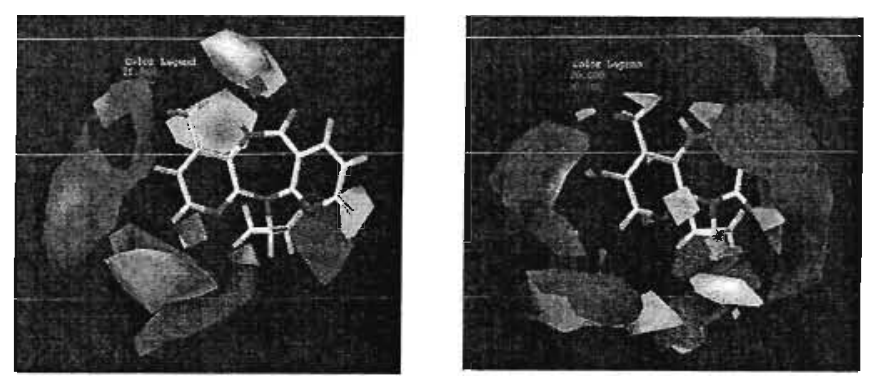

Figura II.2.3.1-2. Exemplo ilustrativo de gráficos resultantes de análise CoMFA aplicada a derivados antiretrovirais (ISHIKI, H.M., GALEMBECK,E., AMARAL, A.T.13 ${ }^{\text {th }}$ European Symposium on QSAR: Rational Approach to Drug Design, Dusseldorf, Germany, Agosto, 2000). (ANEXO XI)

Aspectos teóricos, metodológicos, limitações e exemplos de aplicações recentes de sucesso são disponíveis em artigos de revisão (KUBINYI, 1993; KUBINYI, FOLKERS, MARTIN, 1998; KUBINYI, 1998).

Recentemente, tem sido possível o estudo de similaridades por campos moleculares de compostos bioativos (inibidores) apresentando estruturas totalmente distintas, uma vez que as conformações bioativas podem ser alinhadas de acordo com os campos moleculares utilizados no estudo $\operatorname{CoMFA}$, independentemente de sobreposição átomo a átomo ou por hipótese de farmacóforo (KUBINYI, 1993, KUBINYI 1998; KUBINYI, HAMPRECHT, MIETZNER, 1998).

\section{Análise Comparativa de Índices de Similaridades Moleculares (CoMSIA, Comparative Molecular Similarity Indices Analvsis)}

Mais recentemente, introduziu-se a Análise Comparativa de Índices de Similaridades Moleculares (CoMSIA, Comparative Molecular Similarity Indices Analysis) (KUBINYI 1993; KLEBE, 1994, KLEBE, 1999; KUBINYI, HAMPRECHT, MIETZNER, 1998 ).

A análise comparativa dos índices de similaridade molecular (CoMSLA) é aproximação alternativa para se realizar os estudos de $Q S A R-3 D$. Este método permite considerar as várias propriedades físico-químicas. Os mapas de contorno resultantes podem ser interpretados. Este método corrige algumas deficiências inerentes devido às 
funções potenciais de Lennard-Jones e de Coulomb utilizados na versão original do CoMFA. Estes dois potenciais são semelhantes à superficie de van der Waals e produzem singularidades nas posiçõe $s$ atômicas. Como conseqüência, a energia potencial expressa nos pontos da grade nas proximidades da superfície sofrem mudanças drásticas. Esta região é justamente a que contém as descrições importantes para a análise de $Q S A R$. Para permitir valores de energia inaceitavelmente grandes, a evolução dos potenciais é normalmente restrita a regiões fora da molécula e requer a definição de alguns valores de corte determinados arbitrariamente.

$\mathrm{Na}$ tentativa de se contornar estes problemas, pode-se utilizar a análise comparativa dos índices de similaridade molecular (CoMSIA). A similaridade é expressa em termos de diferentes propriedades físico-químicas, a saber: ocupação estérica, cargas atômicas parciais, hidrofobicidade local e doadores e aceptores de ligação de hidrogênio. Utilizando-se um átomo de prova comum, pode-se calcular os índices de similaridade para um grupo de moléculas previamente alinhadas com espaçamento de grade regular. Uma das maiores vantagens do CoMSIA em relação ao CoMFA é a melhor habilidade para se visualizar e interpretar as correlações obtidas em termos das contribuições dos campos.

Aspectos teóricos, metodológicos, vantagens e limitações e aplicações recentes de sucesso são disponíveis na literatura (KUBINYI, HAMPRECHT, MIETZNER, 1998; KUBINYI, 1998; KIM, GRECO, NOVELLINO, 1998). A maioria dos modelos CoMFA e CoMSIA foram aplicados para descrever as interações ligante-proteína, sendo estas descritas por constantes de afinidade ou constante de inibição. A aplicação de CoMFA para descrever dados de sistemas in vivo não são recomendadas.

No grupo determinamos para as séries de derivados 5-nitrofurânicos (séries IV.I, IV.II e IV.III) os valores de $\mathrm{IC}_{50}$ - concentração inibitória de $50 \%$ do crescimento normal. Estes foram avaliados contra a bactéria Gram-positiva: Staphylococcus aureus (ATCC-25923) e a Gram-negativa: Caulobacter crescentus (NA1000) e foram considerados como parâmetro biológico. Para os derivados nitrofurânicos da série IV.I, foi também investigada a redução por NADPH, mediada por extratos não purificados da bactéria Caulobacter crescentus, determinando-se a velocidade máxima $\left(\mathbf{V}_{\max }\right)$ de redução por NADPH avaliada em condições aeróbicas e catalisada pelo extrato nãopurificado de Caulobacter crescentus. Como relatado em detalhes no memorial, os 
estudos foram co-orientados pelas Profa. Dra. Astréa M. Giesbrecht (ICBUSP) e Profa.Dra. Suely Lopes Gomes (IQUSP) e fizeram parte da tese de doutorado de José Ricardo Murari Pires.(ANEXO DII).

Em nossos laboratórios a partir destes dados foram realizadas análises CoMFA, com o objetivo, entre outros de aplicar esta metodologia. Torna-se importante relatar, que os resultados obtidos (modelos CoMFA) embora promissores - descrevendo dados de literatura - não podem ser enviados para publicação, até que se tenha os valores das constantes de afinidade ou de inibição. Assim optamos por utilizar e publicar a abordagem QSAR tradicional (ANEXO VI), até que tenhamos o parâmetro biológico adequado. Os dados de inibição disponíveis no grupo, até o momento, foram obtidos para a enzima não purificada para Caulobacter Crescentus. As ana'lises QSAR para esta série de compostos consta do CAPÍTULO III.2.

No laboratório, a partir de dados de literatura, em um trabalho realizado em colaboração com Prof. Dr. Sérgio Galembeck, FFCL-RP, USP, realizamos análises CoMFA de análogos não nucleosídeos inibidores da transcriptase reversa, (NNRTI)do virus HIV-1, a partir de dados de literatura. Nesta colaboração, co-orientei o mestrado de Hamilton Ishiki, focalizando no aspecto de alinhamento dos compostos. Mais recentemente estes foram estendidos para análise CoMSIA. Como descrito em detalhes no memorial, os resultados relativos ao alinhamento foram publicados (ANEXO XI); seleciondos para apresentação oral na Gordon Conference em QSAR, Tilton, USA (2001) (DOC.9.3.6.1-40) e fazem parte da dissertação de mestrado de Hamilton Ishiki, por mim co-orientada. (ANEXO M-5). A discussão desses resultados não foram incluídos nesta tese.

No laboratório, atualmente estamos aplicando CoMFA para outros sistemas, como referido, em detalhes no memorial.

\section{II.2.3.2. $Q S A R$ 3D quando a estrutura do receptor é conhecida}

\section{Planejamento de ligantes com auxílio de computador}

As primeiras abordagens de planejamento de ligantes assistida por computador foram propostas nos programas DOCK e GROW. Na sua versão original executa, em um banco de dados de estruturas $3 \mathrm{D}$, busca por ligantes que se ajustam a uma cavidade de ligação meramente por complementariedade geométrica. Por outro lado, o programa 
GROW inicia com um simples fragmento-semente, por exemplo, um grupo amida, capaz de interagir com o sítio ativo e então diferente aminoácidos em diferentes conformações são adicionados a este fragmento. Apenas os melhores candidatos são selecionados e o processo repetido várias vezes, até que um peptídeo de um determinado tamanho tenha sido gerado no sítio ativo.

O programa LUDI (BÖHM, 1992, BÖHM 1993), após a definição da região do sítio ativo pelo usuário, identifica automaticamente todos os grupamentos doadores e aceptores de ligação de hidrogênio, bem como áreas hidrofóbicas alifáticas e aromáticas. O programa gera, a seguir, vetores e regiões no espaço, nas quais grupos complementares do ligante devem ser colocados. Numa próxima etapa, LUDI, executa uma busca por potenciais ligantes em bancos de estruturas $3 \mathrm{D}$ de moléculas pequenas e médias. Cada candidato é, a seguir, testado em todas as diferentes orientações possíveis e modos de interações. Novas versões do programa já consideram a flexibilidade conformacional dos ligantes em potencial. Depois de uma avaliação aproximada, contando o número de interações e considerando as superposições desfavoráveis de superfícies de van der Waals, os candidatos remanecentes são priorizados por uma função simples mas eficiente. Esta função estima a energia de interação com base na energia de formação de ligações de hidrogênio, áreas de contato hidrofóbico e o número de ligações passíveis de rotação do ligante (BÖHM, 1994).

\section{Outros métodos}

Outras estratégias metodológicas, atualmente cada vez mais utilizadas envolvem estudos de $R M N$ e de Cristalografia de raios- $X$

Em alguns casos os resultados de análises em $Q S A R$ podem ser relacionados com as estruturas tridimensionais do ligante no sítio de ligação, graças à Cristalografia de

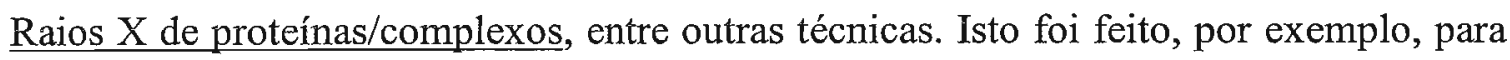
dihidrofolato redutase (DHFR), papaína outras proteases, tripsina e outras serina proteases e acetilcolinesterase (BLANEY, HANSCH, 1990). No entanto, o planejamento racional de ligantes e análise QSAR ficam extremamente difíceis, ou praticamente impossíveis (principalmente para o desenvolvimento da pesquisa na indústria), por exemplo, se a estrutura 3D do sítio de ligação é desconhecida, o que é no entanto a situação bastante comum ao se aplicar métodos de QSAR ou de QSAR-3D. 
Assim, o planejamento de fármacos baseado na estrutura é hoje uma técnica bem estabelecida e aplicada em muitas indústrias farmacêuticas. Desta forma, o investimento na síntese como procura de compostos mais ativos pode ficar extremamente reduzido aplicando-se técnicas em $Q S A R-3 D$ associada ao de novo design, como, por exemplo, através do programa LUDI (BÖHM, 1992; KUBINYI, 1993; BÖHM et al., 2000).

Estes avanços ocorreram através de estudos envolvendo a cristalização e a determinação estrutural por difratometria de raios $\mathrm{X}$ da proteína como de seus complexos com ligantes fornecem informações mais detalhadas sobre os aspectos estruturais que são relevantes para a atividade biológica (BÖHM, KLEBE, 1996) .

Mais recentemente, introduziu-se a Química Combinatória no planejamento de fármacos. A idéia chave de se testar tantos compostos quanto possível e tanto mais rápido quanto o possível é mais ou menos o objetivo da química combinatória e levou ao termo "design irracional de compostos ativos" (KUBINYI, 1998). Isto não significa que os conceitos de "design racional" tenham sido abandonados. Na verdade existe interesse crescente por programas de computadores capazes de detectar e diferenciar a(s) dissimilaridade(s) entre compostos. Por meio da Química Combinatória e da triagem de grande quantidade de compostos pode-se sugerir mais facilmente novas estruturas-base, mas não necessariamente os candidatos selecionados irão conduzir diretamente a novos fármacos. Deste modo, a otimização das estruturas-base obtidas é parte essencial no processo de design de compostos biologicamente ativos. Estudos de QSAR se fazem necessários para analisar as informações obtidas no screening dos compostos obtidos por Química Combinatória. Para tanto, são necessários bancos de dados de compostos tanto com grande diversidade como focados em pequena diversidade, como por exemplo em série de análogos. 


\section{CAPÍTULO HI. Exemplos de Análises de $O S A R / O S A R-3 D$ aplicadas a diferentes sistemas}

\section{Apresentação}

O Segundo Capítulo desta tese, apresentou e discutiu em detalhes diferentes aspectos das propriedades físico-químicas ou estruturais responsáveis pela resposta biológica, em especial as de natureza: eletrônica/polar; hidrofóbica e estérica, para as séries de compostos estudados no grupo.

Neste Terceiro Capítulo, baseando-nos no discutido anteriormente, apresentamos e discutimos os modelos de $Q S A R / Q S A R-3 D$ propostos, ou seja as correlações estrutura-resposta biológica obtidas, para séries de compostos estudados no grupo. Estes aspectos foram selecionados e apresentados, nesta tese, da seguinte forma:

1. Análises $Q S A R$ de compostos bioativos - estruturalmente análogos à procaína ou à procainamida, avaliados quanto à toxicidade aguda (ANEXOS I a V e ANEXO IX)) e avaliados quanto à atividade inibidora/bloqueadora da transmissão do impulso nervoso (ANEXO V) (ANEXO M-7) (ANEXO M-8) e,

2. Análises $Q S A R / Q S A R-3 D$ de compostos bioativos, em especial de derivados nitrofurânicos 5-substituídos com atividade antibacteriana, (ANEXO D-2) (ANEXO VI) (ANEXO VII ) (ANEXO XIV) 


\section{1. Análises $Q S A R$ de compostos bioativos, estruturalmente análogos à procaína ou à procainamida: Séries I e II avaliados quanto à toxicidade aguda (ANEXOS I a $\mathrm{V}$ e ANEXO IX) e Séries III avaliados quanto à atividade inibidora/bloqueadora da transmissão do impulso nervoso (ANEXO V) (ANEXO M-7) (ANEXO M-8)}

\section{SÉRIES I :}

Série Ia: Cloretos de [2-benzoiloxi-etil]dimetilamônio, para-substituídos

Série Ib: Cloretos de [2-benzoiloxi-etil]dimetilamônio, orto-substituídos e,

Série Ic: Cloretos de [2-benzoiloxi-etil]dimetilamônio, meta-substituídos .

\section{SÉRIE II :}

Série Ia_Cloretos de $N$-[(dimetilamino)metil]benzamidas, para-substituídos .

\section{SÉRIE III :}

Série IIIa. Brometos de[2-(benzamido)etil]benzildimetilamônio, para-substituídos e,

Série IIIb. Cloretos derivados da procaína, com estruturas diversas

É conhecido que anestésicos locais (AL) bloqueiam a condução nos sistema nervoso periférico, modificando a cinética de abertura e fechamento dos canais de sódio, dependentes de voltagem (STRICHARTZ, 1987). ALs, no entanto, não interferem somente no sistema nervoso periférico. Assim, qualquer membrana excitável, como as do cérebro ou do coração, podem ser alteradas por estes fármacos, se estes atingirem concentrações suficientes no tecido, causando efeitos sistêmicos. Embora alguns destes efeitos tenham se mostrado de interesse terapêutico, a maioria deles é indesejável, pois são tóxicos. Neste sentido, os sistemas nervoso central (CNS) e cardiovascular (CVS) são, em geral, os mais freqüentemente afetados. Assim, a toxicidade letal de AL é o resultado destes efeitos indesejáveis e, consequentemente será, em termos do mecanismo molecular, bastante complexo (STRICHARTZ, 1987). Considerando que as toxicidades tanto a níveis de CNS como de CVS aparentemente aumentam em paralelo com a potência anestésica, supôs-se que as mesmas características estruturais modulariam as potências tanto anestésica como tóxica. Esta questão, no entanto, merece ainda ser examinada em termos realmente moleculares e quantitativos. 
Assim, na literatura são encontrados relatos, por exemplo utilizando a abordagem de $Q S A R$, cujos resultados não concordam, irrestritamente, com este ponto de vista (STRICHARTZ, 1987, RECANATINI, et al, 1988). Estas divergências de interpretação refletem a complexidade dos mecanismos, em nível molecular, envolvidos nos efeitos tanto anestésico como tóxico (STRICHARTZ, 1987). Recanatini (RECANATINI, et al, 1988) realizando estudos de $Q S A R$ para a toxicidade aguda de série de análogos da lidocaina, mostraram uma contribuição negativa para o termo lipofílico, sendo a validade destas observações discutida e questionada pelos próprios autores. Esta discussão torna-se interessante na medida que, de forma geral, observa-se um paralelismo entre a potência anestésica local e a toxicidade aguda, especulando-se que os mesmos fatores estruturais estariam modulando tanto a potência anestésica como a toxicidade aguda. Estas especulações, no entanto, não são totalmente confirmadas por estudos recentes de QSAR (CALIENDO, 1995). Este ponto permanece ainda em aberto, e é objeto de interesse de nossos estudos bem como discutido na literatura.

Os valores da toxicidade aguda foram determinados em experimento animal, ou seja, em sistema biológico bastante complexo. Assim, em uma abordagem rigorosa, a proposição de modelos, utilizando-se análise de $\boldsymbol{Q S A R}$, torna-se ainda mais complexa pois é necessário a inclusão de parâmetros envolvendo informações sobre o metabolismo, a bioacumulação etc. (HANSCH, 1995; HANSCH, 1995; DEARDEN, 1991 ainda não disponíveis. Os resultados por nós obtidos, até o momento, no entanto, tem seu papel para o entendimento destes mecanismos envolvendo sistemas bastante complexos (AMARAL et al, 1997):

Em um trabalho em colaboração, para cada composto, a toxicidade aguda foi determinada em camundongos, e expressa por $\mathrm{DL}_{50}$, e considerada como parâmetro biológico. Estes estudos foram efetuados e orientados pelo Prof. Dr Antonio Carlos de Oliveira do Departamentos de Farmacologia, ICBUSP, SP ou pela Profa.Dra. Márcia Gallacci e sua equipe nos Departamentos de Farmacologia do Instituto de Biociências da UNESP, Botucatu, São Paulo. Os valores da dose letal média $\left(\mathrm{DL}_{50}\right)$, do coeficiente de correlação (C.C.), do desvio padrão (G); do intervalo de confiança (I.C.), e do $\log 1 / \mathrm{DL}_{50}$, obtidos para a cada composto das séries.

Do ponto de vista estrutural, a grande maioria dos anestésicos locais atualmente utilizados na prática médica apresenta em comum uma porção lipofilica, geralmente um 
sistema aromático, uma cadeia carbônica alifática intermediária e uma porção hidrofílica, freqüentemente o grupo amino substituído. Embora o mecanismo de ação ao nível molecular ainda não esteja totalmente esclarecido, considera-se que o equilíbrio entre as porções lipofílica e hidrofilica influencia significativamente a atividade biológica, modulando sua potência anestésica local. Alguns autores, por outro lado, consideram que a distribuição eletrônica do grupo carbonila, presente na maioria dos anestésicos locais, tem papel importante para estabelecimento desta atividade (STRICHARTZ, 1987). Assim, propõe-se que a atividade anestésica local seja afetada por grupos substituintes presentes no anel aromático, através de seus efeitos tanto hidrofóbicos como também de natureza polar, ou seja de efeitos indutivo e de ressonância. Sabendo-se que estes últimos afetam diretamente a distribuição eletrônica no oxigênio carbonílico, propõe-se, como conseqüência, que a polaridade do grupo carbonila possa estar, em princípio, modulando a atividade do anestésico local.

Neste contexto, como apresentado e discutido em detalhes na CAPÍTULO II desta tese, decidimos estender para as interação composto-sistema biológico nossos conhecimentos oriundos de estudos sistemáticos das variações da posição da banda de absorção da carbonila na região do infravermelho de ésteres dos ácido alilacético, que nos indicavam que $\boldsymbol{V}_{\mathbf{C}=\mathbf{o}}$ podem ser consideradas como sendo resultado dos efeitos polares dos grupos substituintes, expressando, portanto, variações na distribuição eletrônica no grupo carbonila. Embora estudos sistemáticos já tenham sido bastante descritos na literatura (AMARAL, 1976) recomenda-se que para cada série estudada estes sejam validados, através por exemplo da aplicação da equação tipo-Hammett aos dados. Assim, verificamos a influência dos efeitos eletrônicos de grupos substituintes sobre a polaridade do grupo carbonila, medida através de sua freqüência de absorção no Infravermelho, em série de compostos análogos à procaina e à procainamida e, a seguir, verificamos a aplicabilidade da equação tipo-Hammett aos valores de $v_{C=0}$, visando analisar a validade de sua utilização como parâmetro eletrônico experimental a ser aplicado em Análises de Hansch (QSAR).

Como já ressaltado no CAPÍTULO II desta tese, a importância da avaliação experimental do parâmetro estrutural (como por exemplo a polaridade do grupo carbonila visando ao mapeamento da distribuição eletrônica no grupo) pode ser compreendida considerando-se, inicialmente, as limitações inerentes aos parâmetros 
eletrônicos da literatura (CHARTON, 1981, HANSCH, 1990). Estes são definidos a partir de reações químicas simples, ou seja, para sistemas mais simples do que o sistema biológico. Desta forma, as interações polares que ocorrem na interação compostosistema biológico podem ser mais complexas do que aquelas presentes nos sistemas utilizados para definir os referidos parâmetros como, por exemplo, o parâmetro $\sigma$ de Hammett, definido a partir da ionização de ácidos benzóicos substituídos. Assim, em estudos de $Q S A R$ que utilizam a propriedade eletrônica recomenda-se, na medida do possível, o emprego de parâmetros experimentais.

Resumindo: Os resultados obtidos validam a utilização de $v_{(\mathrm{C}=\mathbf{0})}$ como parâmetro eletrônico experimental adequado para emprego em estudos de QSAR.. Adicionalmente, análise dos resultados sugerem influência do efeito eletrônico de grupos substituintes sobre a atividade anestésica local para a série de oito compostos da série IIa. A aplicação da Análise de Hansch, no entanto, requer maior número de compostos bem como a análise e estudo de outros fatores envolvidos na interação fármaco-sistema biológico. (ANEXO LX) (ANEXO M-2)

Adicionalmente, trabalhos prévios realizados em nossos laboratórios envolvendo uma análise de $Q S A R$ da toxicidade aguda de série de doze cloretos (série Ia) com estrutura análoga à da procaína, mostraram haver uma maior contribuição relativa da hidrofobicidade, expressa pelo coeficiente de partição aparente, $\log P_{a p p}$, para a toxicidade letal (ANEXO I). No entanto, neste trabalho permaneceu a dúvida se há uma real contribuição do termo lipofílico para a toxicidade, havendo a possibilidade deste termo estar associado, ou correlacionado, ao volume/polarizabilidade ocupado pelo grupo ou molécula toda, medido por MR. Esta dúvida foi descartada ao planejarmos uma série, sendo esta ampliada para 16 compostos. (A discussão pertinente a seleção de compostos para QSAR já foi apresentada na CAPÍTULO II desta tese. A seguir, foi realizada a análise de $Q S A R$ da toxicidade letal, $\mathrm{LD}_{50}$, de série de 16 cloretos de $\mathrm{N}$ (dimetilamino)etil-benzoatos para-substuídos, da série por nós planejada e sintetizada, (série Ia). No modelo gerado, foram analisados os parâmetros físicoquímicos/estruturais respectivamente eletrônicos, lipofílicos e de polarizabilidade obtidos no grupo- responsáveis para a toxicidade aguda. Avaliamos as contribuições relativas de cada parâmetro, mostrando haver uma maior contribuição relativa da lipofilicidade, expressa pelo coeficiente de partição aparente, $\log P_{\mathrm{app}}$, para a toxicidade 
letal, $\mathrm{LD}_{50}$. A aplicação e análise $Q S A R$ sugere uma lipofilicidade ótima, correspondendo a um máximo de atividade.

Concordando com os resultados anteriores observados no grupo, observamos uma pequena contribuição positiva associada ao termo lipofílico. No entanto, foi descartada a dúvida se há uma real contribuição do termo lipofílico para a toxicidade. (ANEXO IV). Os resultados sugerem, no entanto, um possível efeito associado à estabilidade do composto bem como efeitos de proximidade de grupos polares. Estes estariam modulando tanto a lipofilicidade bem como a toxicidade aguda.

Em nosso laboratório, a escolha de séries de benzoatos para este estudo, foi feita, entre outras, pelo conhecimento da baixa toxicidade observada, em geral, para os correspondentes produtos de biotransformação, exceção feita ao para-amino derivado (STRICHARTZ, 1997). Procurava-se, deste modo, não introduzir mais este fator (toxicidade dos produtos de biotransformação), a ser considerado em etapas posteriores. No entanto, os compostos se mostraram, frente ao sistema biológico, muito mais susceptíveis a hidrólise, dentro do período requerido para o experimento, do que seria desejado. Este fato, poderia vir não só dificultar os experimentos biológicos, mas também pode comprometer a precisão dos valores de $\mathrm{LD}_{50}$, como observado por exemplo para o 4-SO $\mathrm{SO}_{2} \mathrm{CH}_{3}$ derivado.

Como já referido nesta tese mas em outro contexto (CAPÍTULO II), em uma etapa posterior, projetamos, uma série de benzamidas, Série II a, com atividade anestésica local, visando obter compostos menos sensíveis a hidrólise mantendo-se, no entanto, o caráter hidrofóbico. Para as duas séries, Séries Ia e IIa, os efeitos das modificações estruturais sobre a lipofilicidade e a toxicidade foram também analisados. (ANEXO III). A análise de QSAR, ou seja, a análise das modificações estruturais sobre as variações observadas na toxicidade aguda foi verificada através da análise $Q S A R$ "mista" (HANSCH, et al 1995, KUBINYI, et al 1993) aplicada às duas séries de compostos, através da introdução da Variável Indicadora, $\mathbf{I}_{(\mathrm{OCOCH} 2)}$, que expressa a presença/ausência deste fragmento. A aplicação da análise de regressão indicou uma contribuição positiva do termo lipofílico para a toxicidade aguda. A inclusão da Variável Indicadora, com contribuição negativa, resultou em uma melhor correlação. A contribuição negativa da Variável Indicadora pode ser explicada considerando-se um possível envolvimento da estabilidade do composto (grau de hidrólise) juntamente com 
efeitos de proximidade de grupos polares sobre a lipofilicidade (LEO, 1993). O valor do coeficiente de regressão associado a Variável Indicadora, reflete portanto os efeitos de interações (intramoleculares) entre o oxigênio carbonílico e o nitrogênio quaternário, efeitos devido a ionização, expressos pelos valores de $\mathrm{pK}_{\mathrm{a}}$ e estabilidade frente a hidrólise, nas duas séries de compostos. Este(s) efeito(s) de natureza intramolecular(es), explicam os maiores valores de $\log P_{\text {app }}$ observados para a série de benzamidas quando comparados aos correspondentes benzoatos. Efeito similar pode ser observado na comparação com os valores de logP, calculados pelo programa CLOGP, que não considera a carga positiva no nitrogênio quartenário (LEO, 1992, HANSCH, 1995).

Para alguns compostos da série, a toxicidade cardíaca, $\mathrm{ED}_{30}$ foi avaliada, não sendo, no entanto, posssivel se efetuar QSAR. Estes estudos foram efetuados e orientados pelo Prof. Dr Antonio Carlos de Oliveira do Departamentos de Farmacologia, ICBUSP, SP Discussão pertinente, apresentada no memorial.

O trabalho realizado aplicando a abordagem mista (Hansch e Free-Wilson) para esta série de compostos, séries Ia e IIa, foi publicado (ANEXO III) e foi o tema da dissertação de mestrado de Yoshinori Miyazaki (não defendida) e de vários projetos de iniciação científica.

Ainda visando obter compostos mais estáveis frente à hidrólise, nosso laboratório realizou análises de QSAR de séries de análogos da procaína, orto-substituídos. Este trabalho foi publicado (ANEXO II) e foi o tema da dissertação de mestrado de Sylvia Regina de Mattos Miguel (ANEXO M-3). Como discutido no CAPÍTULO II desta tese, os compostos com substituintes na posição orto (mono-e di-susbtituídos) apresentam uma maior atividade $\left(\mathrm{LD}_{50}\right)$ devido provavelmente a um menor grau de hidrólise - quando comparados com os para-substituídos - considerando um possivel efeito estérico dos substituintes na posição orto. Para os 28 compostos (séries Ia e Ib, $\mathrm{n}=28$ ), um melhor modelo é obtido ao se incluir - além dos termos lipofílicos e eletrônico - um termo descrito pelo parâmetro $E_{\mathcal{S}}(A M D)$ proposto por Fujita e colaboradores (SOTOMATSU, 1990), tornando as correlações significativas. Este descreve os efeitos estéricos de substituintes nas posições 2- e 6- no anel aromático. Como discutido no CAPÍTULO II desta tese, modelo similar é observado ao se incluir 
uma Variável Indicadora, $\mathbf{I}_{\text {orto, }}$ definida no modelo misto proposto por (Hansch-Free Wilson).

Para 10 compostos desta série, foram determinadas - em colaboração - os valores da toxicidade cardíaca, "in vitro", expressa por $\mathrm{DE}_{30}$. Considerando o pequeno número de compostos testados $(n=10)$ os valores de $\mathrm{DE}_{30}$ embora promissores, não permitem uma análise de QSAR, como discutido no CAPÍTULO II desta tese e na apresentação do memorial.

Ainda para os compostos classificados nesta tese como série I, efetuamos um

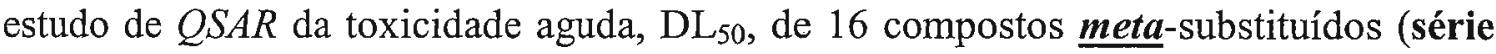
Ic). Esta foi planejada e preparada em nosso laboratório. Através da aplicação da abordagem de Hansch, verificamos a natureza e a contribuições relativas dos efeitos eletrônicos, lipofilicos e relacionados à refratividade molar (MR) exercidos pelos substituintes, sobre a toxicidade aguda, determinada em camundongos. Este trabalho, foi tema da dissertação de mestrado de Wander Alves de Souza (ANEXO M-4). Em um trabalho em colaboração, para cada composto, os valores da dose letal média ( $\left.\mathrm{DL}_{50}\right)$; do coeficiente de correlação (C.C.), do desvio padrão (G); do intervalo de confiança (I.C.) e do $\log 1 / \mathrm{DL}_{50}$, foram determinados em camundongos e considerados como parâmetro biológico para QSAR. Estes estudos foram efetuados e orientados pela Profa. Dra. Márcia Gallacci e sua equipe no Departamento de Farmacologia do Instituto de Biociências da UNESP, Botucatu, São Paulo.

O melhor modelo de $Q S A R$ proposto para toxicidade aguda da série de cloretos da série Ic é descrito pela equação III.1-1:

$\log 1 / \mathrm{DL}_{50}=+0.13( \pm 0.06) \log P_{a p p}+0.21( \pm 0.07) \mathrm{MR}_{3}+2.19( \pm 0.10) \quad$ equação III.1$\mathrm{n}=16 \quad \mathrm{r}=0.923 \quad \mathrm{~s}=0.080 \quad \mathrm{~F}=37.480 \quad \mathrm{r}_{\mathrm{cv}}^{2}=0.766 \quad$ S PRESS $=0.100$

As diferenças observadas entre os valores de $\log 1 / \mathrm{DL}_{50}$ calculados - pelo modelo expresso pela equação - e os valores obtidos experimentalmente são praticamente constantes dentro do erro experimental, sendo de no máximo $0,11(4,5 \%)$, ou seja, dentro do erro estatisticamente aceitável.

A análise dos valores dos coeficientes da regressão indicam uma contribuição positiva tanto de $\log P_{\text {app }}$ como de $\mathrm{MR}_{3}$, para a toxicidade letal. Deve-se salientar que a contrbuição da lipofilicidade para a toxicidade letal é, porém, pequena $(0,13)$. Nesta série

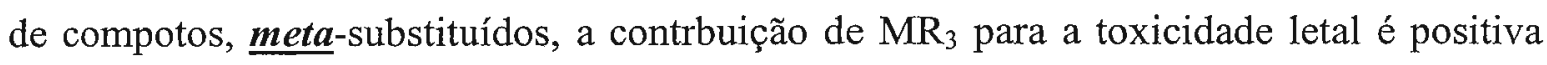


$(0,21)$. Este valor, sendo positivo sugere, como discutido anteriormente e ressaltado na literatura por Dearden (DEARDEN, 1991) que $\mathrm{MR}_{3}$ esteja expressando interações dispersa ou semi-polares. Esta afirmação é reforçada, considerando-se a intercorrelação não significativa $(\mathrm{r}=0,18)$ entre o parâmetro lipofilico $\left(\log P_{\text {app }}\right)$ e $\mathrm{MR}_{3}$ (obtido da literatura).

Uma análise comparativa preliminar entre a séries Ia e Ic (cloretos de [2-(Xbenzoiloxi)etil]dimetilamônio para-substituídos e meta-substituídos) sugere, para as duas séries uma contribuição positiva (pequena) de $\log P_{\text {app }}$. (respectivamente 0,24 e 0,13). Este valor é considerado pequeno segundo uma análise crítica de Hansch (HANSCH, 1995).

A validade da aplicação dos modelos parabólico e bilinear foi avaliada. O modelo parabólico, embora ainda não significativo estatisticamente sugeriu um $\log P_{\text {app }}$ ótimo de 0.32. Este resultado, nos indica que mais compotos precisam ser incluídos na série, visando aumentar a faixa de variação do lipofilicidade na série, para que o modelo parabólico "sugerido", seja validado com a inclusão de mais dados. Comentário análogo se aplica ao parâmetro eletrônico, em especial para esta série de substituintes na posição meta.

Mais recentemente, com a efetiva colaboração do Prof. Antônio José Lapa e sua equipe (UNIFESP) e, a partir de dados de literatura as séries I e II foram reavaliadas quanto a atividade biológica analisada.

Assim, da literatura sabe-se que após a elucidação dos receptores nicotínicos musculares da acetilcolina, o foco das atenções de estudos farmacológicos concentrouse na investigação dos sítios receptores de compostos análogos de curares (SOUCCAR, 1999), compostos análogos de toxinas de serpentes, de rãs etc.(BIXEL, 2000; BIXEL, 2001) e, de compostos análogos de anestésicos locais (ARIAS, 1997; ARIAS, 1998). Nos anos 90 estudos farmacológicos e neuroquímicos mostraram que receptores nicotínicos da acetilcolina modulam a liberação de acetilcolina bem como de outros neurotransmissores em diferentes regiões do cérebro. Recentemente, foi relatado que receptores nicotínicos neuronais pós-sinápticos medeiam a transmissão sináptica rápida no sistema nervoso central (SOUCCAR, 1999). Estas evidências fizeram surgir o uso potencial de ligantes colinégicos específicos na terapia farmacológica de distúrbios comportamentais e outras desordens centrais como Mal de Alzheimer e Parkinson (SOUCCAR, 1999). Neste sentido, agentes considerados como agentes colinégicos 
clássicos estão sendo novamente analisados, buscando-se sondas (ligantes) que possam vislumbrar novas funções dos subtipos de receptores nicotínicos (SOUCCAR, 1999).

Desta forma, com base nestes trabalhos e a significativa colaboração com o grupo liderado pelo Prof. Dr. Antônio José Lapa e sua equipe do Departamento de Farmacologia do Instituto de Farmacologia da Universidade Federal de São Paulo, EPM, decidimos, recentemente, estudar a atividade bloqueadora neuromuscular dos compostos, classificados nesta tese como série IIIa. Este foi tema da dissertação de mestrado de Leonardo Amaral de Siqueira. (ANEXO M-7).

Desta forma, uma série de onze brometo de 2-[(4-X-benzamido)etil] benzildimetilamônio, série IIIa, estruturalmente análogos à procainamida foi planejada, como discutido anteriormente no CAPÍTULO II desta tese e, sintetizada. Os valores do coeficiente de partição, $\log P_{\text {app}}$, foram utilizados como parâmetro lipofílico experimental. Os valores de $\delta^{13} \mathrm{C}=\mathrm{O}$, foram determinados e utilizados como parâmetro eletrônico. Adicionalmente, outros parâmetros físico-químicos foram retirados da literatura: $\pi, \sigma_{\mathrm{p}}, \mathfrak{I}, \mathfrak{R}$ e $\mathrm{MR}_{4}$ ou obtidos por cálculo: $\log P_{\text {calc }}$ e $\pi_{\text {exp }}$.

A atividade bloqueadora neuromuscular foi avaliada através do teste clássico em sinapses periféricas de preparações neuromusculares, ou seja, preparações nervo frênico-músculo diafragma de camundongos.

Os valores da concentração inibitória média $\left(\mathrm{IC}_{50}\right.$, em mol/L) capazes de reduzir a contração máxima a $50 \%$ no período de 15 minutos, determinados em preparações nervo frênico-músculo diafragma de camundongos, foram considerados como parâmetro biológico. Os valores de $\mathrm{IC}_{50}$, foram obtidos para os 11 compostos da série IIIa (IIIa.1-IIIa.11) e expressos com nível de confiança de 95\%. Compostos mais potentes apresentam valores de $\mathrm{pIC}_{50}$ maiores enquanto que o oposto é apresentado por compostos menos potentes. Para efeito de comparação (utilizando-se as mesmas condições experimentais) o valor de $\mathrm{pIC}_{50}$ para a procainamida é igual a 2,37. Os valores de $\mathrm{pIC}_{50}$ apresentaram uma faixa de variação de potência de inibição de 1,55 unidades logarítmicas. $\mathrm{O}$ maior valor $\left(\mathrm{pIC}_{50}=4,10\right)$ foi observado para o brometo de 2 [(4- $n$-hexil-benzamido)etil]benzildimetilamônio (composto IIIa.4), enquanto, que o menor valor $\left(\mathrm{pIC}_{50}=2,55\right)$ foi observado para o brometo de 2-[(4-metilsulfonilbenzamido)etil]benzildimetilamônio (composto HIa.11). Para o composto IIIa.7 (X = 4- $\mathrm{NO}_{2}$ ) não foi possível obter soluções aquosas em concentrações adequadas para se 
observar o bloqueio da contração muscular, pois este se mostrou insolúvel em água em concentrações maiores que $0,01 \mathrm{~mol} / \mathrm{L}$. Assim, o valor de $\mathrm{pIC}_{50}$ para o composto IIIa7 não foi determinado, sendo apenas predito pelo modelo de $Q S A R$. Para o composto IIIa.11 $\left(\mathrm{X}=4-\mathrm{SO}_{2} \mathrm{CH}_{3}\right)$, em concentrações na faixa de $4,53 \times 10^{-4}$ a $1,36 \times 10^{-3} \mathrm{~mol} / \mathrm{L}$, foi observado uma potenciação da transmissão neuromuscular, ou seja, houve um estímulo da contração muscular, enquanto que em concentrações mais elevadas foi observado o bloqueio da transmissão neuromuscular. Pascuzzo e colaboradores (PASCUZZO,1993) estudando a natureza das interações da Piridostigmina em receptores nicotínicos da acetilcolina - porém utilizando o sistema nervo-músculo de rã - também observaram que em concentrações baixas a piridoestigmina causa uma potenciação do estímulo muscular e em concentrações mais elevadas o mesmo composto apresenta bloqueio da contração muscular.

Considerando-se a procainamida como referência, os maiores valores de $\mathrm{pIC}_{50}$ observados para a série III.a, podem ser atribuídos, entre outros, ao grupo catiônico presente na série. Esta afirmação é reforçada considerando-se dados de literatura ( IKEDA, 1984). Assim, por exemplo, foi observado que a introdução de grupo metila na cadeia lateral da bupivacaina causa um aumento da potência inibitória (avaliada em preparações músculo sartório-nervo ciático de rãs).<smiles>CN(C)CC(=O)Oc1ccc[n+](C)c1</smiles>

(1)<smiles>CCN(CC)CCNC(=O)c1ccc(N)cc1</smiles>

(2)

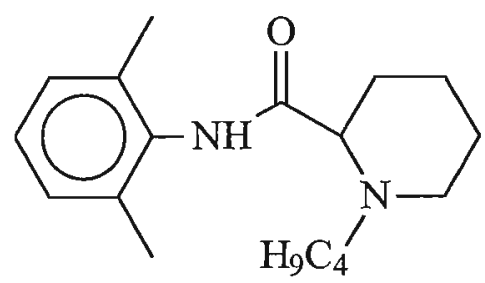

(3)

Estruturas da piridostigmina (1); da procainamida. (2) e da bupivacaína (3). 
A avaliação da(s) natureza(s) e a(s) contribuição(ões) relativa(s) dos parâmetros físico-químicos e estruturais envolvidos no bloqueio da transmissão neuromuscular foi feita aplicando-se a abordagem extratermodinâmica ou abordagem de Hansch. As análises de $Q S A R$ sugerem uma dependência positiva (pequena) da lipofilicidade para o bloqueio da transmissão neuromuscular expresso por $\mathrm{pIC}_{50}$, segundo o modelo proposto expresso pela equação III.2:

$$
\begin{aligned}
& p I C_{50}=0,39( \pm 0,11) \log P_{a p p}{ }^{7,40}+3,07( \pm 0,13) \\
& n=11 ; r=0,938 ; s=0,18 ; F=66,20 ; Q^{2}=0,84 ; s_{P R E S S}=0,21
\end{aligned}
$$$$
\text { equação III.2 }
$$

Este modelo explica a maioria da variação nos valores de $\mathrm{pIC}_{50}$. O poder de predição do modelo proposto avaliado pelo valor de $\Delta \mathrm{pIC}_{50}$ mostrou o ajuste dos dados de atividade biológica, obtidos experimentalmente, ao modelo, não sendo maior do 0,19 , exceto para o composto IIIa.7 $(\mathrm{X}=\mathrm{Br})$ que foi de 0,42 .

Adicionalmente, a aplicação dos modelos parabólico e bilinear foi verificada para os valores de $\mathrm{pIC}_{50}$ da série IIIa $(\mathrm{n}=11)$. Os resultados obtidos se mostraram estatisticamente não significantes. Apesar do intervalo de variação dos valores de $\log P_{\text {app }}$ ter sido de 4,39 unidades logarítmicas, este pode ter sido ainda pequeno para que fosse observado um modelo não linear, ou seja, um modelo parabólico ou bilinear. 


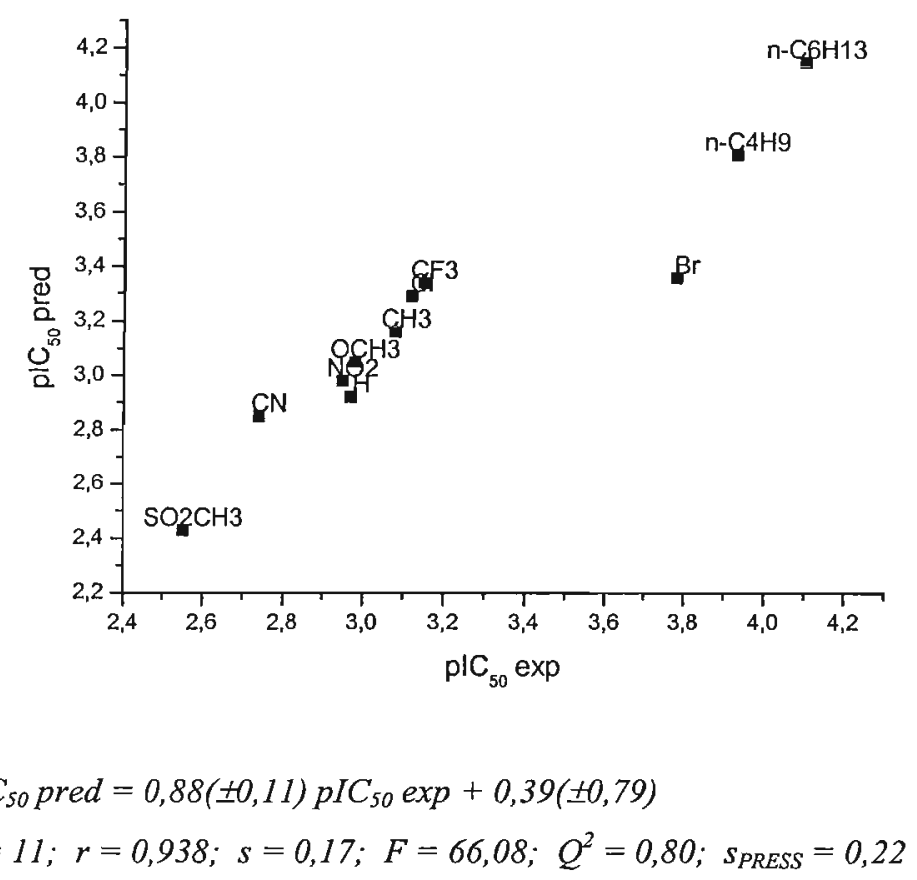

Figura III.1-1. Gráfico e equação obtidos da correlação entre os valores de $\mathrm{pIC}_{50}$ determinados experimentalmente em função dos valores de $\mathrm{pIC}_{50}$ preditos pelo modelo $Q S A R$

O efeito da lipofilicidade sobre o bloqueio da transmissão neuromuscular é descrito na literatura (STENLAKE, 1981). Assim, Bixel e colaboradores (BIXEL, 2000; BIXEL, 2001), estudaram a relação estrutura-atividade de uma série de 14 poliaminas (análogas da philantoxina) como inibidores não competitivos (NIC's) do receptor nicotínico da acetilcolina (nAChR). Os autores observaram que o aumento do tamanho do grupo da cabeça hidrofóbica (introduzindo grupos aromáticos volumosos) causa um aumento da afinidade pelo receptor quando comparada com a philantoxina. Os resultados foram explicados, assumindo-se que a hidrofobicidade da cabeça hidrofóbica é uma característica estrutural importante para a excepcional afinidade observada, embora a lipofilicidade não tenha sido determinada ou mesmo calculada pelos autores.

Com base nestes resultados (ANEXO M-7), no qual demonstramos tanto a importância da presença de um grupo catiônico terminal como da lipofilicidade para o bloqueio da transmissão neuromuscular, decidimos continuar os estudos visando esclarecer as interações hidrofóbicas determinantes da potencial atividade bloqueadora 
neuromuscular, para uma série de 10 derivados da procaína, série IIIb.. Este foi tema da dissertação de mestrado de Alberto Malvezzi, recentemente apresentada e aprovada (ANEXO M-8). Manuscrito sobre este resultados esta sendo elaborado para ser enviado para publicação.

Como já descrito no CAPÏTULO II, desta tese, esta série foi planejada e os compostos foram sintetizados, no laboratório e os correspondentes parâmetros físico químicos determinados, em especial os relacionados a lipofilicidade e a ionização. De modo análogo para cada composto, os valores da atividade biológica foram obtidos pelo Prof. Dr. Antônio José Lapa e sua equipe do Departamento de Farmacologia do Instituto de Farmacologia da Universidade Federal de São Paulo, EPM.

Com relação ao modelo $Q S A R$ este não pode, ainda ser proposto. Pois, embora o sistema de avaliação da atividade bloqueadora da transmissão neuromuscular tenha sido adequada, a série de compostos estudada não gerou valores válidos para a construção das correspondentes curvas dose-resposta. Desta forma, os valores de $\mathrm{IC}_{50}$ obtidos somente para três compostos da série estudada foram insuficientes, em número, para serem utilizados em uma análise de QSAR. Estes resultados foram apresentados nesta tese, exemplificando uma das dificuldades - ou por isso mesmo desafios - relatadas em detalhes no memorial, com respeito a obtenção do parâmetro biológico.

Estudos futuros podem ser realizados com o objetivo de verificar a atividade anestésica local para os compostos da série estudada, avaliando-se a perda da sensibilidade à estimulação sensorial, em cobaias, ou em estudos mais sofisticados de eletrofisiologia (patch clamp). Poder-se-á, assim, fornecer subsídios para elucidar as contribuições relativas da forma catiônica e da forma neutra, respectivamente de compostos ionizáveis com atividade anestésica local. 


\section{2. Análises $Q S A R / Q S A R-3 D$ de compostos bioativos, em especial de derivados nitrofurânicos 5-substituídos com atividade antibacteriana, (ANEXO D-2) (ANEXO VI) (ANEXO VII ) (ANEXO XIV)}

Estão apresentadas e discutidas neste segundo capítulo as análises $Q S A R / Q S A R$ $3 D$ realizadas para três séries de derivados nitrofurânicos 5-substituídos, com atividade antibacteriana. As séries de compostos estão agrupadas e nomeadas nesta tese, como:

Séries IV.I. 2-(5-nitro-2-furfurilideno)-3-oxo-2,3-di-hidrobenzofuranos substituídos

Séries IV.II. 1-(2-hidróxi-fenil)-3-(5-nitro-2-furil)-2-propen-1-onas) substituídas

Séries IV.III 1-(2-acetilóxi-fenil)-3-(5-nitro-2-furil)-2-propen-1-onas) substituídas

Os resultados deste trabalho constam de duas publicações (ANEXO VI) e (ANEXO VII) e foi parte do tema da tese de doutorado de José Ricardo Murari Pires (ANEXO D-II) e de vários projetos de iniciação científica; de projeto de pósdoutoramento da Dra. Elizabeth Cheng. Os valores dos parâmetros biológicos, determinados pelo doutorando José Ricardo foram realizados com a co-orientação da Profas. Dras. Astréa Giesbrecht (Departamento de Farmacologia, ICBUSP) e Suely Lopes Gomes (Departamento de Bioquímica, IQUSP, SP).

Como apresentado em detalhes no memorial, este tema, consta de projetos que estão em andamento no laboratório, incluídos os realizados em colaboração com Prof. Dr. Roy Bruns, IQ-UNICAMP (ANEXO XIV). Estes aspectos serão brevemente referidos neste capítulo.

Sabe-se da literatura (EDWARDS, 1990; DEBNATH, 1993) que compostos contendo as estruturas básicas respectivamente de 2-(5-nitro-2-furfurulideno)-3-oxo2,3-dihidrobenzofuranos substituídos (A); 2-(5-nitro-2-furfurilideno)-1-indanonas substituídas ( $\underline{\mathbf{B}})$ bem como 2-(5-nitro-2-furfurilideno)-1-tetralonas (C) mostraram-se ativos contra bactérias Gram-positivas e Gram-negativas, fungos e protozoários.

Nestes trabalhos, as variações observadas tanto nos valores da atividade antimicrobiana, bem como variações no espectro de ação destas séries de derivados nitrofurânicos com o tipo; natureza e posição dos grupos substituintes são apresentadas 
e discutidas. No entanto, estas são feitas somente de modo qualitativo, embora, um grande número $(>100)$ compostos tenha sido sintetizado e suas atividades quantificadas, pelos valores da concentração mínima inibitória (MIC) entre elas para Staphylococcus aureus.

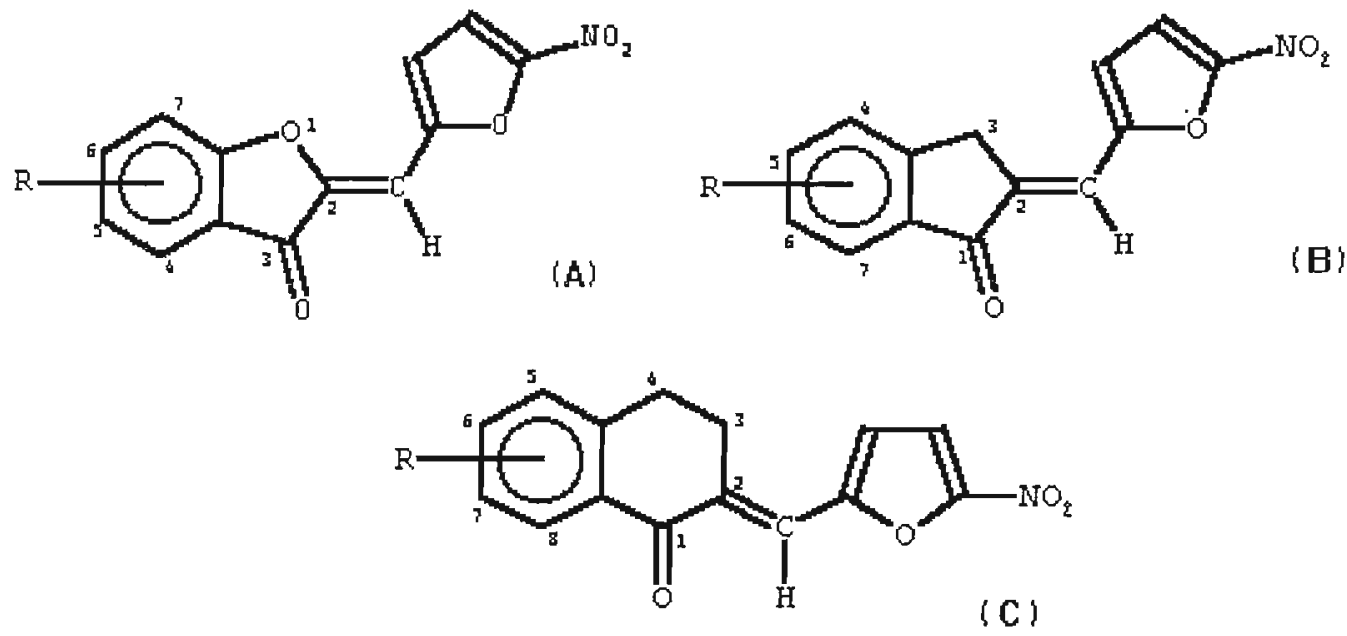

Figura III.2.1. Séries de derivados 5-nitrofurânicos, com atividade antibacteriana avaliada (MIC) para Staphylococcus aureus retiradas da literatura.

(A) 2-(5-nitro-2-furfurulideno)-3-oxo-2,3-di-hidrobenzofuranos substituídos

(B): 2-(5-nitro-2-furfurilideno)-1-indanonas substituídas $\mathrm{e}$

(C) :2-(5-nitro-2-furfurilideno)-1-tetralonas substituídas

Com base nestes trabalhos e sabendo-se que o mecanismo de ação proposto para atividade de compostos nitro-aromáticos esta relacionado com a redução do grupo nitro in vivo, gerando espécies tóxicas decidimos realizar em nosso laboratório, análise de QSAR de séries planejadas de derivados nitrofurânicos, adotando os critérios já apresentados e discutidos em detalhes nesta tese, com o objetivo de verificar a relação entre a estrutura química e a potência antimicrobiana destes compostos.

Neste contexto, realizamos as análises de $Q S A R / Q S A R-3 D$ para três séries de derivados nitrofurânicos,. a saber: nove 2-(5-nitro-2-furfurilideno)-3-oxo-2,3-dihidrobenzofuranos, 5-X-substituídos, sendo $\mathrm{X}=-\mathrm{H},-\mathrm{CH}_{3},-\mathrm{C}_{2} \mathrm{H}_{5},-\mathrm{CH}_{2} \mathrm{CH}_{2} \mathrm{CH}_{3} ;-\mathrm{Cl}$, $\mathrm{Br},-\mathrm{OCH}_{3},-\mathrm{CN}$ e $-\mathrm{NO}_{2}$ ) (série IV.I) e dez análogos flexíveis 1-(2-hidróxi-fenil)-3-(5nitro-2-furil)-2-propen-1-onas) 5-X-substituídas, sendo $\mathrm{X}=-\mathrm{H}, \mathrm{CH}_{3},-\mathrm{C}_{2} \mathrm{H}_{5},-\mathrm{Cl}$, e - 
$\mathrm{NO}_{2}$ ) (série IV.II) e os correspondentes 1-(2-acetilóxi-fenil)-3-(5-nitro-2-furil)-2propen-1-onas 5-X-substituídas, sendo $\mathrm{X}=-\mathrm{H},-\mathrm{CH}_{3},-\mathrm{C}_{2} \mathrm{H}_{5},-\mathrm{Cl}, \mathrm{e}-\mathrm{NO}_{2}$ ) (série IV.III)<smiles>[R]c1ccc2c(c1)C(=O)/C(=C/c1ccc([N+](=O)[O-])o1)O2</smiles>

Série IV.I

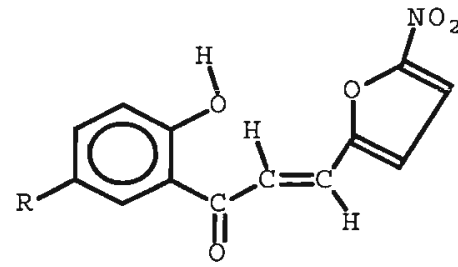

Série IV.II<smiles>[R]C=C(C=C1CC2CC1O2)C(=O)c1cc([2H])ccc1OC(C)=O</smiles>

Série IV.III

Os dezenove compostos foram planejados para um estudo de $Q S A R$ - como referido anteriormente nesta tese - e, a seguir preparadas por métodos descritos na literatura, sendo quinze, na época, inéditos. Para cada um dos compostos das três séries, estes parâmetros foram determinados experimentalmente e/ou calculados e/ou retirados da literatura. (ANEXO VI). Para as três séries, os valores de $\mathrm{IC}_{50}$ foram avaliados para a bactéria Gram-positiva: Staphylococcus aureus (ATCC-25923) e a Gram-negativa: Caulobacter crescentus (NA1000) e foram considerados como parâmetros biológicos. Dos compostos estudados, dezenove apresentaram atividade contra Staphylococcus aureus e catorze contra Caulobacter crescentus. Adicionalmente para a série IV.I, foi também avaliada a redução dos derivados nitrofurânicos, por NADPH, realizada em condições aeróbicas e catalisada pelo extrato não-purificado de Caulobacter crescentus.

Apesar da diferença estrutural no que diz respeito a parede destas bactérias, a correlação observada, expressa pela equação III.2.1, sugere que as mesmas características estruturais devem estar cotribuindo para a atividade antibacteriana. 
Para todos os compostos exceto IV.II.5 e IV.III.5:

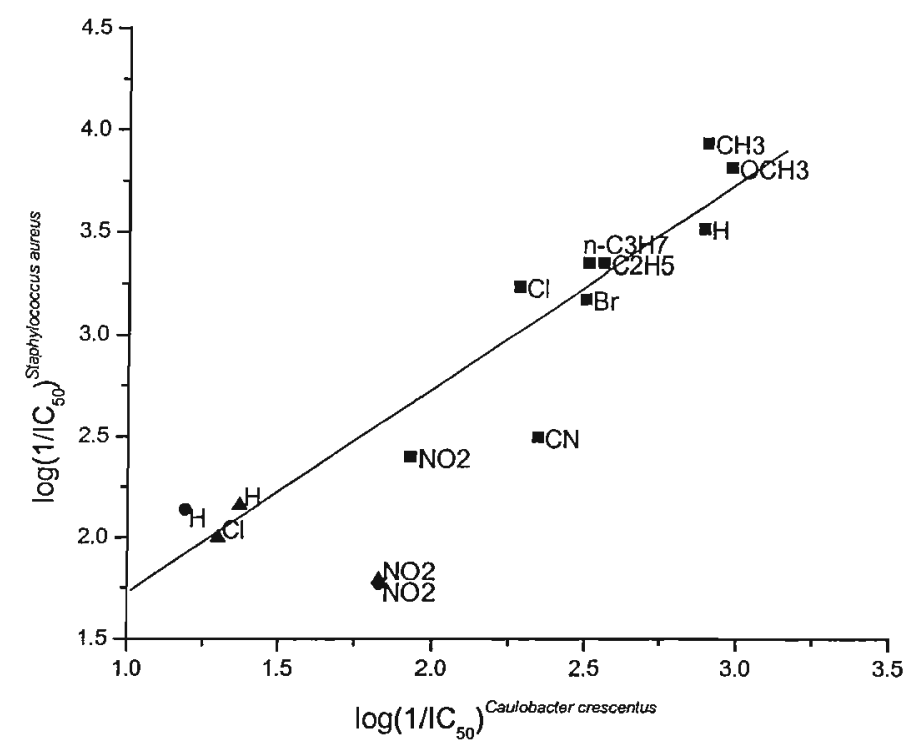

$\log \left(1 / \mathrm{IC}_{50}\right)^{\text {S. aureus }}=1.01( \pm 0.26) \log \left(1 / \mathrm{IC}_{50}\right){ }^{\text {C crescentus }}+0.72( \pm 0.61)$

$\left(\mathrm{n}=12, ; \mathrm{r}=0.937 ; \mathrm{s}=0.252 ; \mathrm{F}=72.104 ; \mathrm{Q}^{2}=0.837 ; \mathrm{s}-\mathrm{PRESS}=0.291\right.$ ) (equação III.2.1)

Figura III.2.1 Gráfico de valores de $\mathrm{pIC}_{50}$ obtidos para as bactérias Gram positiva (Staphylococcus aureus, ATCC-25923) e Gram-negativa (Caulobacter crescentus, NA 1000) para os sets IV.I (ם), IV.II (•) e IV.III ( $\mathbf{\Delta})$.

A análise de $Q S A R$ tradicional (modelo extra-termodinâmico de Hansch) indicou contribuição negativa do termo eletrônico para as atividades antibacterianas avaliadas contra Staphylococcus aureus e contra Caulobacter crescentus. Verificamos, que os compostos das séries IV.II e IV.III, apresentando maior flexibilidade, são por volta de dez vezes menos ativos do que seus correspondentes análogos rígidos da série IV.I.

Os resultados obtidos estão resumidos na TABELA III.2-1 (ANEXO VI).

Para os compostos da série IV.I, o melhor modelo é observado utilizando-se a constante de substituinte $\sigma_{\mathrm{p}}$.

Set I:

$\log \left(1 / \mathrm{IC}_{50}\right)^{\text {S. aureus }}=-1.30( \pm 0.42) \sigma_{\mathrm{p}}+3.43( \pm 0.17)$ 


$$
\left(\mathrm{n}=9, \mathrm{r}=0.941 ; \mathrm{s}=0.189 ; \mathrm{F}=54.062 ; \mathrm{Q}^{2}=0.829 ; \mathrm{s}-\mathrm{PRESS}=0.231\right)
$$

Observa-se que os compostos mais flexíveis (séries IV.II e IV.III) são todos menos ativos que os respectivos análogos rígidos (série IV.I). Para estes o melhor modelo de $Q S A R$ é obtido utilizando-se a constante de substituinte $\sigma_{\mathrm{m}}$. (equação.6).

Sets II, III, except compound II.3:

$$
\begin{aligned}
& \log \left(1 / \mathrm{IC}_{50}\right)^{\text {S. aureus }}=-0.63( \pm 0.20) \sigma_{\mathrm{m}}+2.21( \pm 0.07) \\
& \left(\mathrm{n}=9 ; \mathrm{r}=0.945 ; \mathrm{s}=0.077 ; \mathrm{F}=57.892 ; \mathrm{Q}^{2}=0.832 ; \mathrm{s}-\mathrm{PRESS}=0.096\right)
\end{aligned}
$$

Podendo-se ainda observar que a a suceptibilidade da atividade antibacteriana ao efeito de substituinte também diminui, em relação a série IV.1.

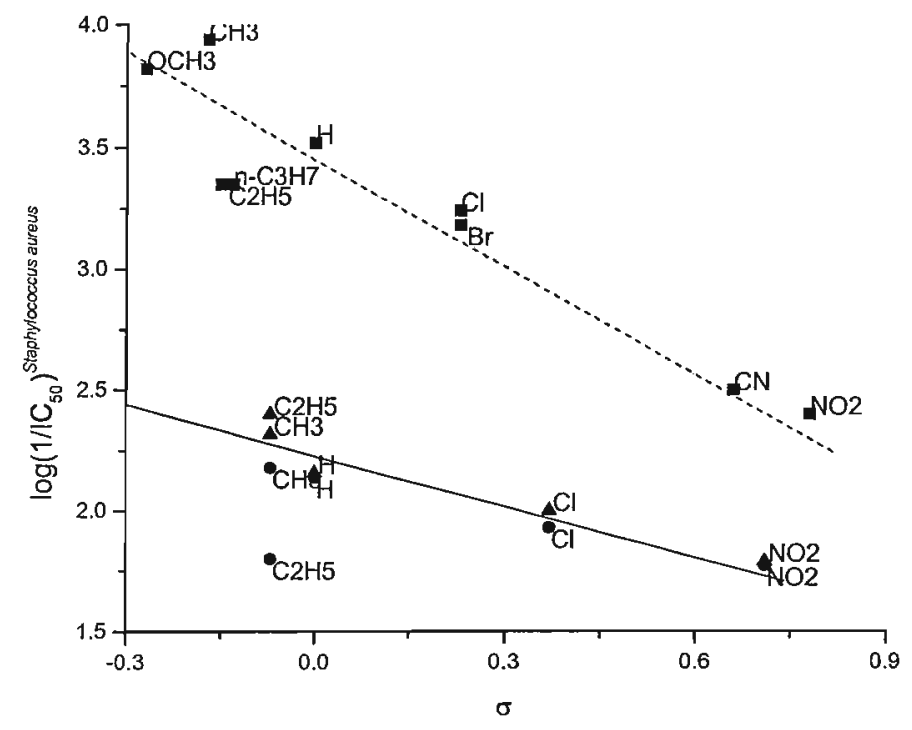

Figura III.2.2 Gráfico dos valores de $\mathrm{pIC}_{50}$ para Staphylococcus aureus (ATCC25923) para as séries IV.I ( $\boldsymbol{\square})$, IV.II (•) e IV.III (A) versus os valores adequados $\sigma$ Hammett, $\sigma_{\mathrm{p}}$ para set I e $\sigma_{\mathrm{m}}$ para os sets IV.II e IV.III.

Para poder se expressar a atividade das três séries estudadas em uma única equação, fez-se necessário, empregar a abordagem chamada mista. Esta envolve a introdução da variável indicadora $\mathbf{I}_{\mathbf{a b s}}$, indicando a presença ou ausência do anel benzofurânico na estrutura, como discutido no segundo capítulo nesta tese. (Equações 8 -12 ). 
$\underline{\text { Sets I,II and III: }}$

$$
\begin{aligned}
& \log \left(1 / \mathrm{IC}_{50}\right)^{\text {S. aureus }}=-0.82( \pm 0.38) \Im-1.59( \pm 0.70) \Re-1.04( \pm 0.21) \mathrm{I}_{\mathrm{abs}}+ \\
&+3.26( \pm 0.20) \\
&\left(\mathrm{n}=19 ; \mathrm{r}=0.970 ; \mathrm{s}=0.195 ; \mathrm{F}=78.429 ; \mathrm{Q}^{2}=0.905 ; \mathrm{s}-\mathrm{PRESS}=0.246\right)
\end{aligned}
$$

Sets I,II and III:

$$
\begin{aligned}
& \log \left(1 / \mathrm{IC}_{50}\right)^{S . \text { aureus }}=-0.67( \pm 0.20) \Sigma \sigma-1.31( \pm 0.19) \mathrm{I}_{\mathrm{abs}}+3.49( \pm 0.15) \\
& \left(\mathrm{n}=19 ; \mathrm{r}=0.968 ; \mathrm{s}=0.195 ; \mathrm{F}=117.428 ; \mathrm{Q}^{2}=0.909 ; \mathrm{s}-\mathrm{PRESS}=0.233\right)
\end{aligned}
$$

Todos os compostos, exceto III.5- and III.5:

$$
\begin{aligned}
& \log \left(1 / \mathrm{IC}_{50}\right)^{\text {C. crescentus }}=-0.73( \pm 0.39) \sigma_{\mathrm{p}}-1.30( \pm 0.28) \mathrm{I}_{\mathrm{abs}}+2.64( \pm 0.15) \\
& \left(\mathrm{n}=12 ; \mathrm{r}=0.964 ; \mathrm{s}=0.188 ; \mathrm{F}=59.128 ; \mathrm{Q}^{2}=0.875 ; \mathrm{s}-\mathrm{PRESS}=0.250\right)
\end{aligned}
$$

Como observado para outros compostos nitro-heterocíclicos descritos na literatura, os modelos de $Q S A R$ propostos não indicaram contribuição significativa da lipofilicidade. E, ainda, utilizando-se a abordagem mista, os modelos QSAR propostos indicam contribuição negativa do termo eletrônico para as atividade antibacteriana avaliada tanto contra Staphylococcus aureus quanto contra Caulobacter crescentus.

Com objetivo de elucidar as características estruturais englobadas na variável indicadora, $\mathrm{I}_{\mathrm{abs}}$, foram aplicadas as seguintes estratégias metodológicas, aos dados aos dados experimentais obtidos neste no laboratório:

\section{Análises $M S A$ e COMFA (OSAR-3D) (ANEXO D-2) e (ANEXO VII)}

Como apresentado e discutido anteriormente nesta tese, os resultados obtidos em QSAR em três dimensões (Analise comparativa de campos moleculares, CoMFA $e$ Análise de forma molecular, MSA) nos auxiliaram a levantar hipóteses para a razão desta diminuição de atividade. Nestas efeitos conformacionais foram considerados demonstrando a importância do anel benzofurânico presente nos compostos da série IV.I. (Vide Tabela II.2.3.1 e equação II.2.3.2, apresentados no segundo capítulo desta tese). As equações obtidas, pelas diferentes abordagens constam do(ANEXO D-2) e do (ANEXO VII) 
II. Análise multivariada aplicada para identificacão dos descritores que discriminam as séries de compostos mais ativos dos menos ativos. Avaliação de suas contrinuiçòes para a atividade.(ANEXO XIV).

Como discutido no segundo capítulo desta tese, os valores do potencial de redução (E) obtidos por voltametria cíclica, não conseguem discriminar as séries, ou seja diferenciar os compostos mais ativos (série IV.I) dos menos ativos (série IV.II). Neste sentido procuramos identificar outros descritores que possam discriminá-las e, assim contribuir para a compreensão da Variável Indicadora, $\mathbf{I}_{\mathbf{a b s}}$.

Aplicando-se análise multivariada (PCA e Cluster Analysis) aos dados disponiveis no laboratório e considerando-se somente as propriedades relativas aos substituintes, estas não permitiram a discriminação entre as séries. A inclusão, no entanto, de parâmetros relativos as propriedades da molécula toda (logP, E, deslocamento químico de $\mathrm{RMN}^{13} \mathrm{C}$ relativo ao anel benzofurânico) permitiu a classificação dos compostos em dois grupos. Estes estudos foram realizados por Dra. Elisabeth Cheng, no seu pós-doutorado em nossos laboratórios. Este trabalho esta sendo continuado com a colaboração do Prof Roy Bruns. Deste modo, aplicamos análise multivariada para identificar as características estruturais que estão sendo responsáveis por essa diferença de atividade. Os resultados obtidos até o momento, indicam um papel importante da dupla ligação. Estes resultados constam de um manuscrito em fase final de redação e foram, recentemente, objeto de uma publicação com corpo editorial, no prelo. (ANEXO XIV).

Vale a pena ressaltar a importância dos dados biológicos. As análises CoMFA e CoMSIA seriam validadas se os parâmetros biológicos fossem os adequados. Como já referido no segundo capítulo desta tese. Comentário análogo se aplica aos dados de literatura, referentes as séries $\underline{\mathbf{A}}, \underline{\mathbf{B}}$ e $\underline{\mathbf{C}}$.

As análises de $Q S A R-3 D(M S A$ e CoMFA) aplicadas aos dados experimentais obtidos neste trabalho bem como dados retirados da literatura (séries $\underline{\mathbf{A}}, \underline{\mathbf{B}}$ e $\underline{\mathbf{C}}$ ) para as atividades observadas contra Staphylococcus aureus indicaram três informações importantes: (1). As menores atividades observadas para os compostos correspondentes das séries IV.II e IV.III bem como para a série $\underline{\mathbf{C}}$, retirada da literatura é explicada considerando-se a tanto presença da região estericamente favorável, no plano definido 
pelo anel nitrofurânico, que deixa de ser ocupada por estes compostos, bem como a presença de uma segunda região, estericamente desfavorável ocupada fora do plano.(2). Os compostos da série $\underline{\mathbf{B}}$, retiradas da literatura apresentam estruturas planares, com atividade intermediária, ocupando a região estericamente favorável.(3). As maiores atividades observadas tanto para a série IV.I como para a série $\underline{\mathbf{A}}$ (da literatura) em relação a série $\underline{\text { B }(r e t i r a d a ~ d a ~ l i t e r a t u r a) ~ s a ̃ o ~ e x p l i c a d a s ~ c o n s i d e r a n d o-s e ~ a ~ c o n t r i b u i c ̧ a ̃ o ~}$ do oxigênio benzofurânico, ocupando uma região favorável a carga negativa. 


\section{REFERÊNCIAS BIBLIOGRÁFICAS}

ABRAHAM, M. H., NIELSEN, G. D., ALARIE, Y. The Ferguson principle and an analysis of biological-activity of gases and vapors. J. Pharm. Sci., Washington, v.83, p. 680-688, 1994.

ABRAHÃO JÚNIOR, O., Estudo Computacional de Inibidores não nucleosídeos da transcriptase reversa do virus HIV-1 (NNRTI), Depto. Química, FFCLRP, USP, Ribeirão Preto, SP 2001 [Tese de Doutorado]

AMARAL, A. T., AMARAL L. DO. Carbonyl stretching frequencies in phenyl carboxylates. J.Org.Chem., Washington,; v.41, p. 1623, 1976.

AMARAL, A.T.DO, MIYAZAKI, Y, CAPOBIANCO, G., FREY, B.Y., STACHISSINI, A.S, MIGUEL,S.R.M., KAWABE, A.B., TAVARES,L.C., GALLACCI, M., CAPRARA, L., OLIVEIRA, A.C. QSAR analysis of the toxicological activity of $\mathrm{N}, \mathrm{N}$-(dimethylamino)ethylbenzoate hydrochlorides. In: WERMUTH, C. G., Ed. Trends in QSAR and Mol.ecular Modeling, 92, Leiden: ESCOM, 1993. p.558-559.

AMARAL, A.T.DO , MIYAZAKI, Y., CAPRARA, L., OLIVEIRA, A.C., QSAR study of series of hydrochlorides of $\mathrm{N}, \mathrm{N}$-[(dimethylamino) ethyl] 4-substituted benzoates. In: SILIPO, C. VITTORIA, A., Eds.QSAR: Rational Approaches to the Design of Bioactive Compound, Amsterdam: Elsevier, 1991. p. 509-512.

AMARAL, A.T.DO, MTYAZAKI Y., TAVARES, L.C., OLIVEIRA, A.C., GALLACCI, M. Structure-activity relationships analysis of the acute toxicity of the $\mathrm{N}$-(dimethylamino) methyl 4-substituted benzamides hydrochlorides, In: F. SANZ, F., GIRALDO, J., MANAUT, F., Eds. QSAR and Molecular Modelling: Concepts, Computational Tools and Biological Applications, Barcelona, J. R. Prous, 1995. p. 134-136.

AMARAL, A.T.-DO, OLIVEIRA, A.C., NEIDLEIN, R., GALLACCI, M., CAPRARA, L., MIYAZAKI, Y. Physicochemical parameters involved in the lethal toxicity of $\mathrm{N}, \mathrm{N}$-[(dimethylamino)ethyl]-4-substituted benzoate hydrochlorides: a QSAR study. Eur. J. Med. Chem., Paris, v. 32, p. 433-443, 1997.

ARIAS, H. R., Bioch. Bioph. Acta, 173, 1376, (1998)

ARIAS, H. R., Brain Res. Rev., 25, 133, (1997).

AVDEEF, A. pH-metric Log-P. 2. refinement of partition-coefficients and ionizationconstants of multiprotic substances. J. Pharm. Sci., Washington, v.82, p. 183-190, 1993.

BARONI,R.V., Aspectos estruturais, mecanismo de formaçào e atividade antimicrobiana de benzilidenotiossemocarbazonas 2- ou 4-, potencialmente quimioterápicas. Faculdade de Ciências Farmacêuticas, USP-SP, 1987 [Dissertação de Mestrado]

BARROS NETO, B., SCARMINIO, I. S., BRUNS, R. Planejamento e Otimização de Experimentos 2. Ed., Campinas: Ed. UNICAMP, 1996.

BIXEL, M.G., KRAUSS, M., LIU, Y., BOLOGNESI, M.L., ROSINI, M., MELLOR, I.S., USHERWOOD, P.N.R., MELCHIORRE, C., NAKANISHI, K., HUCHHO, F. Eur. J. Biochem., 267, 110, (2000).

BIXEL, M.G., WEISE, C., BOLOGNESI, M.L., ROSINI, M., BRIERLY, M.J., MELLOR, I.R., USHERWOOD, P.N.R., MELCHIORRES, C., HUCHO, F. $J$. Biol.Chem., 276, 6151, (2001). 
BLANEY, J.M., HANSCH, C. Application of Molecular Graphics to the Analysis of Macromolecular Structures. In: HANSCH, C., SAMMES,P. G., TAYLOR, J. B., Eds. Comprehensive Medicinal Chemistry. The Rational Design, Mechanistic Study \& Therapeutic Application of Chemical Compounds, v.4. Oxford: Pergamon Press, 1990. p. 459-496.

BÖHM, H.-J. Ligand design. In: KUBINYI, H., Ed. $3 D$ QSAR in Drug Design. Theory, Methods and Applications. Leiden: ESCOM, 1993. p. 386-405.

BÖHM, H.-J. LUDI - Rule-based automatic design of new substituents for enzymeinhibitor leads. J. Comput. Aided Mol. Design, Dordrecht, v.6, p. 593-606, 1992a.

BÖHM, H.-J. The computer-program LUDI - a new method for the de novo design of enzyme-inhibitors. J. Comput. Aided Mol. Design., Dordrecht, v.6, p.61-78, $1992 \mathrm{~b}$.

BÖHM, H.-J. The development of a simple empirical scoring function to estimate the binding constant for a protein ligand complex of known 3-dimensional structure. $J$. Comput Aided Mol. Design, Dordrecht, v. 8, p.243-256, 1994.

BÖHM, H.-J., KLEBE, G. What Can We Learn From Molecular Recognition in Protein-Ligand Complexes for the Design of New Drugs? Angew. Chemie-Int., Engl. ed., Weinheim, v. 35, p.2589-2614, 1996.

BÖHM, H-J., BOEHRINGER, M., BUR,D., GMUENDER,H.; HUBER,W., KLAUS,W., KOSTREWA,D., KUEHNE,H., LUEBBERS,T., MEUNIERKELLER,N., MUELLER, F. Novel Inhibitors of DNA Gyrase: 3D Structure Based Biased Needle Screening, Hit Validation by Biophysical Methods, and 3D Guided Optimization. A Promising Alternative to Random Screening, J.Med Chem, Washington, v. 43, p.2664-2674, 2000.

BURKE, B. J., HOPFINGER, A. J. Advances in molecular shape analysis. In: KUBINYI, H., Ed., 3D QSAR in Drug Design. Theory, Methods and Applications., Leiden: ESCOM, 1993. p. 276-306.

BUTTERWORTH, J.F., STRICHARTZ, G.R., Anesthesiology, 72, 711, (1990)

CALIENDO G, DI CARLO R, GRECO G, GRIECO P, MELI R, NOVELLINO E, PERISSUTI E, SANTAGADA V (1995) Eur J Med Chem 30, 603-608

CHAPMAN, N. B. AND SHORTER, J. In: Advances in linear Free Energy Relationships. Plenum Press: New York., 1972.

CHARTON, M. Electrical effect substituent constants for correlation analysis. Prog. Phys. Org. Chem., v.13, p.119, 1981.

CLOGP, Pomona College, Biobyte, EUA.

COMER, J.; TAM, K. Lipophilicity profiles: theory and measurement. In: TESTA, B.; WATERBEEMD, H.; FOLKERS, G.; GUY, R., eds. Pharmacokinetic optimization in drug research: biological, physicochemical, and computational strategies. Weinheim, Cambridge: Wiley-VCH, 2001. p.275-304.

CRAIG, P. N. Interdependence between physical parameters and selection of substitutent groups for correlation studies. J. Med. Chem., Washington, v.14, p. 680-684, 1971.

CRAIK, D.J., BROWNLEE, R.T.C., In: Progress in Physical Organic Chemistry, vol 14, p. 1-67, (Taft, R.W. ed), Wiley \& Sons, New York, (1983).

CRAMER III, R.D., De PRIEST, S.A., PATTERSON, D.E., HECHT, P. The developing practice of comparative molecular field analysis. In: KUBПNYI, H., Ed., $3 D$ QSAR in Drug Design. Theory, Methods and Applications. Leiden: ESCOM, 1993. p 443-485. 
CRAMER, R. D., PATTERSON, D. E., BUNCE, J. D. Comparative Molecular Field Analysis (COMFA). 1. Effect of shape on binding of steroids to carrier proteins. $J$. Am. Chem. Soc., Washington, v. 110, p. 5959-5967, 1988.

CRIVORI, P., CRUCIANI, G., CARRUPT, P. A.; TESTA, B. Predicting blood-brain barrier permeation from three-dimensional molecular structure. J. Med. Chem., Washington, v.43, p.2204-2221, 2000.

CRONIN, M.T., DEARDEN, J. C., Quant.Struct.Act Relat., 14, 117, (1995)

CRUCIANI, G., CLEMENTI, S., PASTOR, M. GOLPE-Guided Region Selection. Persp. Drug Disc. Design, Dordrecht, v 12, p.71-86, 1998.

DEARDEN, J. C. BRESNEN, G. M..The measurement of partition coefficients. Quant. Struct.-Act. Relat., Weinheim, v. 7, p. 133-144, 1988.

DEARDEN, J.C., BRADBURNE, S.J.A., ABRAHAM, M.H., The nature of molar refractivity. In: SILIPO, C., VITTORIA, A., Eds. QSAR: Rational Approaches to the Design of Bioactive Compound, Amsterdam: Elsevier, 1991. p. 143-154.

DEBNATH, A. K., HANSCH, C., KIM, K. H.; MARTIN, Y. C. Mechanistic Interpretation of the Genotoxicity of Nitrofurans (Antibacterial Agents) Using Quantitative Structure-Activity Relationships and Comparative Molecular Field Analysis, J. Med. Chem., 1993, 36, 1007-1016.

EDWARDS, D.I. DNA binding and nicking agents. In: HANSCH, C., SAMMES,P. G., TAYLOR, J. B., Eds. Comprehensive Medicinal Chemistry. The Rational Design, Mechanistic Study \& Therapeutic Application of Chemical Compounds, v.2. Oxford: Pergamon Press, 1990. p.725-751.

FUJITA, T. The extrathermodynamic Approach to drug desig, In: HANSCH, C., SAMMES,P. G., TAYLOR, J. B., Eds. Comprehensive Medicinal Chemistry. The Rational Design, Mechanistic Study \& Therapeutic Application of Chemical Compounds, v.4. Oxford: Pergamon Press, 1990. p.497-560.

GAILLARD, P., CARRUPT, P. A., TESTA, B., BOUDON, A. Molecular lipophilicity potential, a tool in 3D QSAR - method and applications. J. Comput.-Aided Mol. Des., v.8, p. 83-96, 1994.

HANSCH, C., LEO, A. Exploring QSAR. Fundamental and Applications in Chemistry and Biology, Washington: ACS Professional reference Book, 1995.

HANSCH, C., LEO, A., HOEKMAN, D., Exploring QSAR. Hydrophobic, Electronic and Steric Constants, Washington: ACS Professional reference Book, 1995.

HANSCH, C., LEO, A., TAFT, R. W. A survey of Hammett substituent constants and resonance and field, Chem. Rev., Washington, v.91, p.165, 1991.

HANSCH, C.; SAMMES, P.G.; TAYLOR, J.B., eds. Comprehensive medicinal chemistry: the rational design, mechanistic study and theropeutic application of chemical compounds. Oxford: Pergamon Press, 1990. v.4.

HOPFINGER, A.J., BURKE, B. J. Molecular shape analysis: A formalism to quantitatively establish spatial molecular similarity. In: JOHNSON, M.A., MAGGIORA, G.A., Eds. Concepts and applications of molecular similarity, New York: Wiley, 1990. p. 173-209.

IKEDA, S.R.; ARONSTAM, R.S.; DALY, J.W.; ARACAVA, Y.; ALBUQUERQUE, E.X. Interactions of bupivacaine with ionic channels of the nicotinic receptor electrophysiological and biochemical-studies. Mol. Pharmacol., Bethesda, v.26, n.2, p.293-303, 1984.

ISHIKI, H.M, GALEMBECK, S.E \& AMARAL, A.T.DO Application of two alignments procedures in CoMFA analysis of nevirapine derivative Proceedings of 
$13^{\text {th }}$ European Symposium on Quantitative Structure-Activity Relationships: Rational Approaches to Drug Design, Amsterdam: ESCOM, p.000-000, 2001.

ISHIKI,H.M., Relações Qauntitativas estrutura-atividade QSAR/QSAR-3D de dipiridodiazepinonas, inibidoras da transcriptase reversa do virus da imunodeficiência humana do tipo I (HIV-1). Faculdade de Filosofia, Ciências e Letras de Ribeirão Preto, USP, Ribeirão Preto, SP, 1999 [Dissertação de Mestrado]

KASTENHOLZ, M.A.,PASTOR,M; CRUCIANI, HAAKSMA, E.E.J.; FOX, T. GRID/CPCA: A New Computational Tool To Design Selective Ligands . J. Med. Chem., Washington, v.43, p. 3033-3044, 2000.

$\mathrm{KIM}, \mathrm{K}$. H. 3D-Quantitative structure-activity-relationships - investigation of steric effects with descriptors directly from $3 \mathrm{~d}$-structures using a comparative molecularfield analysis (CoMFA) approach. Quant. Struct.-Act. Relat, v. 11, p. 453-460, 1992.

KIM, K. H., GRECO, G., NOVELLINO, E. A critical review of recent CoMFA applications. Perspect. Drug Discovery Des., v.12, p.257-315, 1998.

KIM, K. H., MARTIN, Y. C. .Direct predictions of linear free-energy substituent effects from 3D structures using Comparative Molecular Field Analysis. .1. Electronic effects of substituted benzoic acids. J. Org. Chem., Washington, v. 56, p.2723-2729, 1991.

KLEBE, G. Structural alignment of molecules. IN: KUBINYI, H. , Ed. 3D QSAR in drug design. Theory, methods and applications, Leiden: ESCOM, 1993. p. 173-199.

KLEBE, G., ABRAHAM, U. Comparative Molecular Similarity Index Analysis (CoMSIA) to study hydrogen-bonding properties and to score combinatorial libraries. J Comput Aided Mol. Des., v.13, p.1-10, 1999.

KLEBE, G., ABRAHAM, U., MIETZNER, T. Molecular similarity indices in a comparative-analysis (CoMSIA) of drug molecules to correlate and predict their biological activity. J. Med. Chem, Washington, v.37, p.4130-4146, 1994.

KLEIN, W., KÖRDEL, W., WEIB, M., POREMSKI, H. J. Updating of the OECD Test Guideline 107 "Partition Coefficient N-Octanol/Water": OECD Laboratory Intercomparison Test on the HPLC Method. Chemosphere, 17, 361-386, 1988.

KUBINYI, H. .Similarity and dissimilarity: A medicinal chemist's view. Persp. Drug Des.Disc., Dordrecht, v.9-11, p.225-252, 1998.

KUBINYI, H. Chance Favors the Prepared Mind. From Serendipity to Rational Drug Design, J. Receptor \& Signal Transduction Research 19, 15-39 (1999).

KUBINYI, H. Combinatorial and computational approaches in structure-based drug design. Curr. Opin. Drug Design Discov., Dordrecht, v.1, p.16-27, 1998.

KUBINYI, H. HAMPRECHT, F.A., MIETZNER, T. Three-Dimensional Quantitive Similarity-Activity Relationships (3D-QSiAR) from SEAL Similarity Matrices, J.Med Chem., Washington, v.41, p. 2553-2564, 1998.

KUBINYI, H. Lipophilicity and drug activity. Prog Drug Res ,v.23, p.97-199, 1979.

KUBINYI, H. QSAR:Hansch Analysis and Related Approaches. In: MANNHOLD, R., KROSGAARD-LARSEN, P., TIMMERMAN, H., Eds. Methods and Principles in Medicinal Chemistry, v.1, Weinheim: VCH, 1993.

KUBINYI, H. Similarity and dissimilarity: A medicinal chemist's view. Persp.Drug Disc.Des., Dordrecht, v.9-11, p.225-252, 1998.

KUBINYI, H. Strategies and Recent Technologies in Drug Discovery, Pharmazie, Eschborn, v.50, p.647-662, 1995.

KUBINYI, H. Structure-based design of enzyme inhibitors and receptor ligands. Curr.Opin.Drug Des.Discov., Dordrecht, v.1, p.4-15, 1998. 
KUBINYI, H. The Free-Wilson method and its relationship to the extrathermodinamic approach. In: HANSCH, C., SAMMES, P. G., TAYLOR, J. B., Ed. Comprehensive Medicinal Chemistry. The Rational Design, Mechanistic Study \& Therapeutic Application of Chemical Compounds, Oxford: Pergamon Press, 1990. p. 589.

KUBINYI, H. Variable selection in QSAR studies .1. An evolutionary algorithm. Quant. Struct.-Act. Relat., Weinheim, v.13, p.285-294, 1994.

KUBINYI, H., Ed. $3 D$ QSAR in Drug Design. Theory, Methods and Applications. ESCOM: Leiden, 1993.

KUBINYI, H., FOLKERS, G., MARTIN, Y. C. 3D QSAR in drug design: ligandprotein interactions and molecular similarity-preface. Perspect. Drug Discov. Des., Dordrecht, v.9-11, V-VIIIB, 1998.

KUBINYI, H., The Quantitative Analysis of Structure-Activity Relationships, In: WOLFF, M.E., Ed. Burger's Medicinal Chemistry, 5. ed, v. 1, New York: Wiley, 1995. p 497-571.

LEO, A. J. Calculating $\log \mathrm{P}_{\text {oct }}$ from structures. Chem. Rev., v.93, p.1281-1306, 1993.

MALVEZZI, A., Estudo comparativo de parâmetros hidrofóbicos e relacionados à ionização de série de derivados da pracaína com atividade bloqueador neuromuscular. Instituto de Química, USP, SP, 2003 [Dissertação de Mestrado]

MALVEZZI, A., POLICASTRO, D. S, DA SILVA, W. C. F. N., AMARAL A.T.DO. Study of ion-pair formation in a set of [(N,N-dimethylamino)-methyl]-4-substituted benzamide hydrochlorides. Proceedings of the second $\log P$ symposium Lipophilicity in Drug Disposition, Lausanne, Suíça, p.000-000, 2001.

MARTIN, Y., Quantitative Drug Design. A Critical Introduction, New York: Marcel Dekker, 1978.

MARTIN, Y.C., LYNN, K.R., Quantitative Structure-Activity Relationships in leucomycin and lincomycin antibiotics $J$. Med. Chem., Washington. v.14, p.1162$1166,1971$.

MARTIN, YC, WILLETT, P., Eds. Designing bioactive molecules, three-dimensional techniques and applications, Washington: ACS, 1998.

MIGUEL, S. R. M., Efeitos de substituintes sobre a polaridade da carbonila, em ésteres de ácidos benzóicos orto-substituídos, com atividade anestésica local. Instituto de Química, USP-SP, 1986 [Dissertação de Mestrado]

PASCUZZO, G.J., AKAIKE, A., MALEQUE, M.A., SHAW, K.P., ARONSTAM, R.S., RICKETT, D.L., ALBUQUERQUE, E.X., Mol. Pharmacol.25, 92, (1983).

PENFOLD, B.R., White, J.C., Acta Cryst, 12, 130, (1959).

PIRES J.R., SAITO C., GOMES S.L., GIESBRECHT, A.M., AMARAL. A.T.-DO Investigation of 5-Nitrofuran Derivatives: Synthesis, Antibacterial Activity and Traditional Quantitative Structure-Activity Relationships, J. Med. Chem., Washington, 44, 3673-3681, 2001.

PIRES, J. R. M., Relações Quantitativas entre a Estrutura Química de Derivados Nitrofurânicos e a Atividade Antimicrobiana contra Caulobacter crescentus e Staphylococcus aureus. Instituto de Química USP, São Paulo, 1998 [Tese de Doutorado]

PIRES, J.R.M. Relações Quantitativas entre a Estrutura Química de derivados nitrofurânicos $e$ a atividade antimicrobiana contra Caulobacter crescentus $e$ Staphylococcus aureus, IQUSP, São Paulo, 1998. [Tese de Doutorado]. 
PLEISS, M.A., UNGER, S.H., The design of test series and the signifiacnce of QSAR. In: HANSCH, C., SAMMES,P. G., TAYLOR, J. B., Ed. Comprehensive Medicinal Chemistry. The Rational Design, Mechanistic Study \& Therapeutic Application of Chemical Compounds", p 561, Oxford: Pergamon Press, , 1990. p.561.

PLISKA, V., TESTA, B., VAN DE WATERBEEMD, H. Lipophilicity in Drug Action and Toxicology, Weinheim: VCH. 1996.

RAMINELLI, C., Estudo da relaçãos quantitativa entre a estrutura química e atividade citotóxica de séries de derivados de bases de Mannich. Instituto de Química, USP, SP, 2001 [Dissertação de Mestrado]

RANDO, D.G.; SATO, D.N.; SIQUEIRA, L.; MALVEZZI, A.; LEITE, C.Q.F.; AMARAL, A.T.; FERREIRA, E.I.; TAVARES, L.C. Potential tuberculostatic agents: topliss application on benzoic acid [(5-nitro-thiophen-2-yl)-methylene]hydrazide series. Bioorg. Med. Chem., Oxford, v.10, n.3, p.557-560, 2002.

RECANATINI, M., VALENTI, P., DA RE P Quantitative structure-activity relationships in a set of local anaesthetic agents . Quant. Struct.-Act. Relat., Weinheim, v.7, p.12-18, 1988.

SCHERRER, R.A. Biolipid pKa values and lipophilicity of ampholytes and ion pairs. In: TESTA, B.; WATERBEEMD, H.; FOLKERS, G.; GUY, R., eds. Pharmacokinetic optimization in drug research: biological, physicochemical, and computational strategies. Weinheim, Cambridge: Wiley-VCH, 2001. p.351-381.

SCHERRER, R.A. Factors affecting ion-pair partitioning and "octanol pKa". Abstract of the $11^{\text {th }}$ European Symposium on Quantitative Structure-Activity Relationships: Computer-assisted lead finding and optimization, Lausanne, Suíça, P-24C, 1996.

SEYDEL, J.K., SCHAPER, K.J. Chemische Struktur und Biologishe Aktivität von Wirkstoffen. Methoden der Quantitativen Struktur-Wirkung-Analyse, Weinheim: VCH, 1979.

SIQUEIRA, L. J. A., Relação quantitativa entre a estrutura química e o bloqueio da transmissào neuromuscular para série de brometos de [2-(4benzamido)etil)]benzildimetilamônio para-substituidos. Instituto de Química, USP, SP 2001 [Dissertação de Mestrado]

SOTOMATSU, T ; FUJITA, T. Quant.Struct._Act.Relat., 9,295-301, 1990.

SOUCCAR, C., BORRÁS, M. R. L., CORRADO, A. P., LIMA-LANDMAN, M. T. R., LAPA, A. J., APPTLA, 49, 268, (1999). .

SOUSA, W. A., Estudo da relação entre a estrutura química e a toxicidade aguda de série de cloretos de [2-(benzoiloxi) etil]-dimetilamônio meta-substituídas, com atividade anestésica local, Instituto de Química, USP-SP, 1997 [Dissertação de Mestrado]

STENLAKE, J. B., In: Burger's Medicinal Chemistry, vol 3, p. 431, (Wolff, M. E. Ed.), Wiley, New York, (1981).

STRICHARTZ, G.R.; RITCHIE, J.M.; ARTHUR, G.R. In: STRICHARTZ, G.R., eds. Local anesthetics. Berlin, New York: Springer Verlag, 1987. p.21-52. (Handbook of experimental pharmacology, v.81).

SWAIN, G. C.; LUPTON, E. C. Field and Ressonance Components of Substituent Effects. J. Am. Chem. Soc. , v.90, 4328-4337, 1968.

SYBYL program, Tripos Inc., USA.

TAVARES, L. C. Efeitos de substituintes sobre a polaridade do grupo carbonila e a atividade anestésica local de $N, N$-[(dimetilamino) metil] benzamidas para- 
substituídas. São Paulo, 1987. (Dissertação - Faculdade de Ciências Farmacêuticas da Universidade de São Paulo).

TAVARES, L. C. Relações quantitativas entre a estrutura química e a atividade antimicrobiana de análogos à nifuroxazida. São Paulo, 1993. [Tese - Faculdade de Ciências Farmacêuticas da Universidade de São Paulo].

TAVARES, L., AMARAL, A. T. Efeito eletrônico de substituintes sobre a polaridade do grupo carbonila e avaliação da atividade anestésica local de $N$ [(dimetilamino)metil]benzamidas 4-substituídas. Rev.Farm.Bioquim.Univ.S.Paulo, São Paulo, v.33, p.123-129, 1997.

TAVARES, L.C., PENNA, TC., AMARAL. A.T.DO Synthesis and biological activity of nifuroxazide and analogs, Boll. Chim. Farmac., Milano, v.136, p.244-249, 1997.

TESTA, B. Pharmacokinetic lead optimization: fine art vs. blind technology. In: TESTA, B.; WATERBEEMD, H.; FOLKERS, G.; GUY, R., eds. Pharmacokinetic optimization in drug research: biological, physicochemical, and computational strategies. Weinheim, Cambridge: Wiley-VCH, 2001.p.615-626.

TOPLISS, J. G.; COSTELLO, R. J. Chance correlations in structure-activity studeis using multiple regression analysis. J.Med. Chem., Washington, v.15, p.1066-1068, 1972.

UNGER, S. H., COOK, J. R., HOLLENBERG, J. S. Simple Procedure for Determining Octanol-Aqueous Partition, Distribution, and Ionization Coefficients by ReversedPhase High-Pressure Liquid Chromatography. J. Pharm. Sci., Washington, v.67, 1364-1367, 1978.

UNGER, S. H., CHIANG, G. H. Octanol-Physiological Buffer Distribution Coefficients of Lipophilic Amines by Reversed-Phase High Performance Liquid Chromatography and Their Correlation With Biological Activity. J. Med. Chem., Washington, v.24, p.262-270, 1981.

WESS, J. BUHL, T., LAMBRECHT, G., MUSTCHLER, E., In: Comprehensive Medicinal Chemistry, vol 3, p. 423-491, (Hansch, C., Sammes, P.G., Taylor, J.B. eds.), Pergamon Press, Oxford, (1990).

ZANNATA, N., RITTNER, R. Synthesis of 4-substituted $\mathrm{N}, \mathrm{N}$-[(dimethylamino) methyl]benzamides: new compounds. J. Pharm. Sci., Washington, v.72, n.7, p.831$832,1983$. 


\section{ANEXOS}

\section{ANEXO I}

Amaral, A.T.-do; Miyazaki,Y; Caprara, L. \& Oliveitra, A.C., A QSAR study of the acute toxicity of a series of hydrochlorides of $N, N$-[(Dimethyl amino)ethyl]4-substituted benzoates. In: QSAR: Rational Approaches on the Design of Bioactive Compounds, $\mathrm{C}$. Silipo e A. Vittoria (ED), Elsevier, New York, 509-512, (1991).

\section{ANEXO II}

Amaral, A. T.-do, Miyazaki, Y; Capobianco, G.; Frey, B.Y.; Stachissini, A.S; Miguel, S.R.M.; Kawabe, A.B.; Tavares, L.C.; Gallacci, M.; Caprara, L. \& Oliveitra, A.C, QSAR analysis of the toxicological activity of $N, N$, [(dimethylamino)ethyl] benzoates hydrochlorides, In: Trends. In QSAR and Molecular Modelling 92, C.G. Wermuth (ED), ESCOM Science Publishers B.V., The Netherlands, 558-559, (1993).

\section{ANEXO III}

Amaral, A.T.-do; Miyazaki, Y.; Tavares, L.C.; Oliveira, A.C. \& Gallacci, M., Structureactivity relationships analysis of the acute toxicity of $N$-dimethylaminoethyl-4-substituted benzamide hydrochlorides. In: QSAR and Molecular Modelling : Concepts, Computational Tools and Biological Applications, F.Sanz, J.Giraldo F.Manaut (ED), J.R.Prous Science Publishers, Barcelona, Spain, 134-136, (1995)

\section{ANEXO IV}

Amaral, A. T.-do; Oliveira, A.C.; Neidlein, R.; Gallacci, M; Caprara, L. \& Miyazaki, Y., Physicochemical parameters involved in the lethal toxicity of $N, N$ - [(dimethylamino) ethyl]4-substituted benzoate hydrochlorides: a QSAR study, Eur. J. Med. Chem., 32, (433 - 443), (1997).

\section{ANEXO V}

Malvezzi, A.; Policastro, D. S; Da Silva, W. C. F. N; Amaral, A. T.-do, Study of ion-pair formation in a set of $[(N, N$-dimethylamino)-methyl]-4 -substituted benzamide hydrochlorides. In Carrupt, Rey (Eds) Proceedings of the second $\log P$ symposium Lipophilicity in Drug Disposition. In: Pharmacokinetics optimization in rug research, Biological Physico-chemical and Computational Strategies. B. Testa, H.van de Waterbeemd, G.Folkers, R Guy (ED), VCH, Zürich, 2001, disponível em CD 


\section{ANEXO VI}

Pires, J.R.; Saito, C.; Gomes, S.L.; Giesbrecht, A.M.; Amaral, A. T.-do. Investigation of 5-Nitrofuran Derivatives: Synthesis, Antibacterial Activity and Quantitative StructureActivity Relationships, J.Med.Chem, 44, 3673-3681, (2001)

\section{ANEXO VII}

Pires, J.R.; Giesbrecht A.M.; Gomes, S.L.; Amaral, A.T-do, Structure-activity relationships of nitrofuran derivatives with antibacterial activity. In: Molecular Modelling and Prediction of Bioactivity, Gundertofte and Jorgensen, eds. (ISBN 0-30646217-6) (C) Kluwer Academic/Plenum Publishers, New York, 290-291, (2000)

\section{ANEXO VIII}

Tavares, L.C.; Penna, T.C. \& Amaral, A. T.-do, Synthesis and biological activity of nifuroxazide and analogs, Boll. Chim. Farmac., 136(3), 244-249, (1997)

\section{ANEXO IX}

Tavares, L.C. \& Amaral, A.T-do, Efeito eletrônico de substituintes sobre a polaridade do grupo carbonila e atividade anestésica local de N-[(dimetilamino) metil] benzamidas 4substituidas, Rev. Farm. Bioq. USP, 32 (2), 123-129, (1997)

\section{ANEXO X}

Amaral, A.T-do ; Montanari, C.A., Quimica Medicinal: 25 anos de planejamento racional de fármacos. Química Nova, 25, 39-44, (2002)

\section{ANEXO XI}

Ishiki, H.M; Galembeck, S.E \& Amaral, A. T.-do, Application of two alignments procedures in COMFA analysis of nevirapine derivative. Proceedings of $13^{\text {th }}$ European Symposium on Quantitative Structure-Activity Relationships: Rational Approaches to Drug Design, ESCOM; Science Publishers B.V., The Netherlands; p.340-344, (2001)

\section{ANEXO XII}

Rando, D. G.; Sato, D. N.; Siqueira, L.; Malvezzi, Alberto;. Leite, C. Q. F; Amaral, A. T.do T., Ferreira', E. I.;. Tavares, L. C., Potential Tuberculostatic Agents. Topliss application on benzoic acid [(5-nitro-thiophen-2-yl)-methylene]-hydrazide series, Bioorg Med Chem, 10, 557-560, (2002) 


\section{ANEXO XII}

Tavares, L.C.; Amaral, L.-do \& Amaral, A. T.-do, A Structure-activity Relationship Study of N,N-[(Dimethyl-amino)methyl]-4-Substituted Benzamide Hydrochlorides. Xth International Symposium on Medicinal Chemistry, pg. 123, (1988)

\section{ANEXO XIV}

Cheng, E.; Haiduke, R.L.A.; Pires, R.; Ishiki, H.; Bruns, R.E. \& Amaral, A. T.-do , Multivariate Analysis of Sets of Antibacterial Nitrofuran Derivatives. Proceedings do $14^{\text {th }}$ European Symposium on QSAR: Designing Drugs: Processes, Problems and Solution, . (2002) 


\section{OBSERVAÇÃO}

NÃO FOI AUTORIZADA A INCLUSÃO DOS TRABALHOS NESTE ARQUIVO 